\title{
Sedimentation adjacent to atolls and volcano-cored carbonate platforms in the Mozambique Channel (SW Indian Ocean)
}

\author{
Counts John ${ }^{1,{ }^{*}}$, Jorry Stephan ${ }^{1,{ }^{*}}$, Leroux Estelle ${ }^{1,{ }^{*}}$, Miramontes Elda ${ }^{2,{ }^{*}}$, Jouet Gwenael ${ }^{1,{ }^{*}}$
}

${ }^{1}$ Laboratoire Géodynamique et Enregistrement Sédimentaire (GM-LGS) - Institut Français de Recherche pour l'Exploitation de la Mer (IFREMER) - Pointe du Diable, 29280 Plouzané, France

${ }^{2}$ CNRS, UMR6538, Laboratoire Géosciences Océan, Institute Universitaire Européen de la Mer Université de Bretagne Occidentale (IUEM-UBO), 29280 Plouzané, France

*Corresponding authors : email addresses : John.Counts@ifremer.fr ; Stephan.Jorry@ifremer.fr ; Estelle.Leroux@ifremer.fr ; Elda.Miramontesgarcia@univ-brest.fr ; Gwenael.Jouet@ifremer.fr

\begin{abstract}
:
Recently acquired data from the lles Eparses (southwestern Indian Ocean) reveal new information about the geomorphology, depositional processes, and sedimentary deposits on the slopes of atolls and atoll-like platforms. The deposits discussed here lie on the deepwater flanks of isolated, inactive volcanos that are capped by shallow, relatively flat carbonate platforms $45-210 \mathrm{~km} 2$ in area. Much of the slope geomorphology is controlled by the underlying volcanic edifice. Steep $\left(\sim 25-35^{\circ}\right)$ upper slopes consist of outcrops of volcanic basement, smooth banks, failure scarps, and channels. Sedimentary features seen in the lower slope and proximal basin (2000-3500 m deep) consist of channels, levees, lobes, and mass transport deposits (MTDs). In places, channels terminate 13-18 km from the platform margin, ending in lobes up to $3.5 \mathrm{~km}$ across, a feature not often seen in modern carbonates. In the subsurface, MTDs are present near all platforms. Within MTDs, seismic character is variable, often consists of chaotic reflections indicative of sediment gravity flow processes. Subsurface units with organized (retro- or progradational) reflections are interpreted as turbidite lobes or MTDs with compressional features. Core taken within lobes and near the base of slopes reveal decimeter-scale turbidites and debrites composed primarily of graded and massive bioclastic grainstones and packstones with abundant neritic skeletal components, interbedded with hemipelagic aragonitic and clay-rich foraminiferal ooze. Slope depositional processes are therefore primarily gravity-driven and occur at different scales; i.e., bed-scale turbidites and muds may be remobilized and redeposited through slope failure and deposition of large MTDs. Dominant wind direction may also play a role in slope sedimentation: leeward slopes are generally less rugose and show increased sedimentation at the toe of the slope. This study thus provides new insight into depositional systems surrounding atoll-like carbonate platforms, and provides a new analogue for similar deposits in the geologic record.
\end{abstract}




\section{Highlights}

- First study to describe the slopes of volcano-cored carbonate platforms in detail. Slope sediments composed of muds and platform-derived carbonate sands - Slopes contain channels, fans, and mass transport deposits. Sedimentation is primarily controlled by inherited topography and dominant winds.

- Excellent example of complete source-to-sink sedimentary system

Keywords : Ato, II Carbonate, Indian Ocean, Slope, Deepwater sediments 


\section{1. Introduction}

64 Sediments on carbonate slopes are well-represented in the

65 ancient geologic record (Blomeier and Reijmer, 2002, and

66 references therein), and are an important component of

67 carbonate depositional systems. However, a detailed,

68 actualistic understanding of these environments in modern

69 settings has been was hampered for many years by the

70 inaccessibility of deepwater deposits in modern oceans

71 (McIlreath and James, 1978), and much work remains to be

72 done. Although many studies have documented the shallow-

73 water portions of modern carbonate platforms and coral atolls 
74 (e.g., Reijjmer et al., 2009; Gischler, 2011; Harris et al., 2011),

75 most existing research on modern deepwater allochthonous

76 carbonates (distinguished here as those predominantly

77 transported into the deep sea from elsewhere, as opposed to

78 cold-water carbonate muds and buildups precipitated in situ)

79 has focused on a limited number of well-known settings (e.g.,

80 the BahamasCaribbean). Although more recent studies have

81 expanded research into new areas (e.g., the Maldives, Papua

82 New Guinea, NE Australia, and New Caledonia; Betzler et al.,

83 2016; Tcherepanov et al., 2008; Dunbar and Dickens, 2000;

84 Yamano et al., 2015, respectively), relatively few studies have

85 been conducted in the southern Indian Ocean. - More studies in

86 new areas and in different geo-environmental settings are

87 required in order to understand the full range of carbonate slope

88 sedimentation around the world.

89 This study examines the submarine slopes of four

90 isolated, volcano-cored atolls and atoll-like carbonate platforms

91 in the southern Indian Ocean (Fig. 1) with the goal of

92 improving our understanding of the depositional processes and

93 products operating on their slopes and nearby basin floors. The

94 deposits formed when carbonate sediments are transferred,

95 deposited, and remobilized on the platform slopes are the focus

96 of this paper, as well as the mechanisms responsible for such

97 deposits. By using seismic, bathymetric, and core data, this

98 study reveals new information about the geomorphology and 
99 sedimentology of these unique depositional settings. Because of

100 their relatively small size (on a scale of tens of kilometers), the

101 entire sedimentary system of each platform can be examined as

102 a whole, forming a complete source-to-sink picture of

103 sedimentation. - This information is used to create a new,

104 unique facies model eontributes to the formation of more

105 complete depositional models-for the type of atoll-like

106 carbonate platforms discussed here, which are lacking in the

107 geological literature, and provides a point of comparison to

108 other, genetically different carbonate systems elsewhere.

109 2. Regional Setting

110 The islands that are the focus of this study (Grande

111 Glorieuse, Europa, Juan de Nova, and Bassas da India) lie

112 within and around the modern Mozambique Channel (MC), an

113 elongate basin in the Indian Ocean between the African

114 continent and the island of Madagascar (Fig. 1). Together, these

115 islands and the waters surrounding them are known as the Iles

116 Eparses, and are part of the French Southern and Antarctic

117 Lands. Islands are the subaerial portions of carbonate platforms

118 that sit atop eonicat-volcanic pinnacles originating from the

119 basin floor. Platform tops are relatively flat and composed

120 entirely of carbonate; there is no central volcanic peak. All are

121 circular/equant in map view, except for Glorieuses, which has a

122 roughly triangular shape. 
124 these structures are not well-studied, but the emergence of all

125 platforms is a result of the interplay between tectonic uplift and

126 subsidence, extrusive volcanic growth, eustasy, and the rate of

127 carbonate aggradation, all of which vary between platforms

128 (Courgeon et al., 2016). Platforms are of different ages and

129 genetic origins and may be related to localized hotspot chains

130 or mantle plumes. The Glorieuses Archipelago (Fig. 2A, 2B) is

131 at minimum Paleocene in age and is a part of a linear ridge of

132 volcanoes that also encompasses the nearby Comoros

133 (Courgeon et al., 2016). It shows no indication of any

134 significant drowning events during its lifespan, and has been

135 interpreted to now be tectonically stable (with a very slow

136 uplift of $\sim 0.012 \mathrm{~mm} /$ year since $\sim 130 \mathrm{ka}$ ) owing to its position

137 away from the Somalia-Nubian plate boundary (Guillaume et

138 al., 2013). Juan de Nova (Fig. 2C, 2D) has been studied very

139 little; however, it likely has a granite core (Förster, 1975) and is

140 not currently undergoing any notable uplift or subsidence

141 (Testut et al., 2016). Bassas da India (Fig. 3A, 3B) and Europa

142 (Fig. 3C. 3D) have been hypothesized to be related to the

143 Quathlamba hotspot, which formed the archipelago up to 60

144 Mya and is currently under Lesotho (Johnston and Thorkelson,

145 2000). Bassas da India specifically has also been shown to have

146 originated in the late Oligocene/early Miocene, and has been

147 volcanically active as late as the early Pleistocene (Courgeon et 
148 al., 2017). Large-scale faulting, structural deformation, and

149 volcanism in Bassas da India and associated submarine banks

150 have been tied to a southern extension of the East African Rift

151 system (Courgeon et al., 2016).

152 Carbonate deposition in the Iles Eparses atolls-began

153 between the Paleocene and Early Miocene, and continues until

154 the present day (Courgeon et al., 2016; 2017). Sediment

155 production was periodically interrupted by episodes of

156 volcanism and subaerial exposure, which occurred during

157 relative sea-level lowstands and resulted in karstification of the

158 platform top. Platform top sediments are generally poorly

159 understood; the sedimentology of Ile Europa was first

160 examined from a geological perspective in the 1960s (Berthois

161 and Battistini, 1969) and on Glorieuses in the 1970s (Battistini

162 and Cremers, 1972; Battistini et al., 1976). These preliminary

163 studies noted the carbonate sediment composition and basic

164 facies asymmetry of platform tops, as well as the existence of

165 paleo-reefs. Sediment atop the Glorieuses platform has been

166 shown by Prat et al. (2016) to be partitioned into five

167 asymmetric facies zones defined by hydrology, storm events,

168 and the distribution of carbonate producing organisms. Here,

169 sediment is remobilized by large sandwaves that ultimately

170 likely migrate off-platform, leading to a relatively continuous

171 supply of sand-sized sediment exported to the platform slope

172 and beyond. Similar asymmetric facies distributions and 
173 winnowing processes can be inferred to be occurring on the

174 tops of other platforms as well (Jorry et al., 2016). Winds are

175 predominantly from the south on all islands except for

176 Glorieuses, where they are primarily from the east (Fig. 1E;

177 Météo France, 2017). Currents come from the east at

178 Glorieuses, but are variable surrounding other islands due to the

179 presence of anticyclonic eddies moving southward through the

180 channel (Schott et al., 2009).

181 Most Iles Eparses platforms lack the defining features of

182 atolls; i.e., a fringing reef and central lagoon. Only Bassas da

183 India fits the definition; the other Iles Eparses are referred to

184 here as 'atoll-like carbonate platforms' to distinguish them

185 from both true atolls and from more traditionally defined

186 carbonate platforms, e.g. the Bahamas. The tops of Glorieuses

187 and Juan de Nova platforms (Fig. 2) contain small asymmetric

188 vegetated islands, but are mostly submerged, whereas the top of

189 Europa (Fig. 3C, 3D) is predominantly subaerial and contains a

190 single large tidal channel surrounded by mangrove forest.

191 Bassas da India does contain a continuous, circular, marginal

192 reef exposed only at low tide, with a fully enclosed inner

193 lagoon (Fig. 3A, 3B). Today, the exposed surface area of all the

194 islands in question (totaling approximately $42 \mathrm{~km}^{2}$ ) is

195 significantly smaller than the predominantly subaqueous

196 portions (around $500 \mathrm{~km}^{2}$, generally ranging between of $0-40 \mathrm{~m}$

197 water depth). All platform tops are composed of carbonate 
sediment, with no volcanic outcrops or sediments visible, and

199 subaerially exposed islands show evidence of recent

200 karstification (Jorry et al., 2016).

201 3. Methodology and Data Set

202 Data used in this study were collected during three

203 research cruises in the MC: PTOLEMEE (R/V L'Atalante;

204 August/September 2014, Jorry, 2014), PAMELA-MOZ1 (R/V

205 L'Atalante; September/October 2014, Olu, 2014), and

206 PAMELA-MOZ4 (R/V Pourquoi Pas?; November/December

207 2015, Jouet and Deville, 2015). Dataset includes:

208

- High-resolution bathymetry and substrate

backscatter/reflectivity measurements of the deep

210

seafloor, using a Kongsberg EM122 multibeam

echosounder

212

- Seismic acquisition with high-speed multichannel

(high-resolution, airgun-sourced ) and CHIRP sub-

bottom profiler (very high-resolution, swept-frequency

source) methods

- Kullenberg and Calypso piston coring systems, used to acquire up to 27 continuous meters of seafloor sediment in $>3000 \mathrm{~m}$ water depth

Depth conversions of seismic lines used a mean acoustic

220 velocity of approximately 1700 meters/second, based on

221 assumptions discussed in Lort et al. (1979) and DSDP Reports

222 from the region (wells 240-242 show velocities from 1.5-1.9 
$223 \mathrm{~km} / \mathrm{s}$ for the Oligocene; Simpson et al., 1974). This method

224 provides a first approximation for sediment thickness when

225 deep core control is not available.

226 A quantitative approximation of the rugosity (roughness)

227 of the Juan de Nova slope was calculated by: 1) drawing the

228

229

230

231

232

233

234

235

236

237

238

239

240

241 diffraction particle size analyzer, capable of measuring all

242 grains from $10 \mathrm{~nm}$ to $2 \mathrm{~mm}$. Carbonate sand composition was

243 determined by counting several hundred individual grains

244 under a reflected light binocular microscope: samples were

245 sieved and split into three size fractions above $63 \mu \mathrm{m}$, and

246 results were combined to provide a bulk composition.

247 Sediments, both sands and muds $\underline{(<63 \mu \mathrm{m}) \text { and carbonate }}$ 
249 imaged and analyzed with a FEI Quanta 200 scanning electron

250 microscope (SEM) equipped with an Oxford Instruments

251 Energy Dispersive Spectroscopy (EDS) detector. X-Ray

252 diffraction (XRD) for mineralogy of muds was performed in-

253 house using a Bruker AXS diffractometer.

\section{4. Results}

\subsection{Geomorphologic elements}

257 4.1.1 Platform tops and terraces

Overall, platforms and their volcanic edifices have a

259 conical morphology with a small, relatively flat top (Fig. 4).

260 The volume of carbonate sediment that has accumulated atop

261 each volcano is unknown; neither deep cores nor deep seismic

262 have been acquired on the tops or upper slopes of the platforms.

263 All investigations of platform tops (by dredging or coring),

264 however, have only yielded carbonates. On Glorieuses and

265 Bassas da India, the main platform tops are attached to deeper

266 submarine terraces 700-750 and 400-500 m below sea level,

267 respectively (Figs. 4A, 4B). The terrace on the northwestern

268 side of Glorieuses is small $\left(3.9 \mathrm{~km}^{2}\right.$; Fig. 4A), and lies between

269 the main platform and a submarine volcanic pinnacle without a

270 flat top (labeled ' $\mathrm{T}$ ' in Fig. 2A). On Bassas da India, the

271 submerged terrace is separated from the main platform by a

272 large fault (Figs. 3A, 4B); previous studies (Courgeon et al., 
273 2017) interpret the terrace as a product of Pliocene-Pleistocene

274 fault movement. Volcanic rocks and small volcanic clasts

275 within sediment have been found on the submarine terrace of

276 Bassas da India.

277 4.1.2 Smooth surfaces and basement outcrops

278 All platform tops show a relatively sharp transition from

279 the shallow, flat top to a steep upper slope with a 25-35 degree

280 gradient (Fig. 4). These upper slope surfaces have the highest

281 overall gradient of anywhere between the platform top and the

282 adjacent abyssal plain, and are smoother than the mid-slope

283 below (Fig 4C). In general, the broad, smooth areas of upper

284 slopes are more contiguous on the leeward side of islands.

285 Seismic lines taken on the middle slope of Europa (Fig. 4D)

286 show that these areas likely contain only a thin veneer of

287 sedimentary cover. Smooth Uupper slopes may be interrupted,

288 however, by steep-sided (generally 30-50 degrees) outcrops of

289 basement (e.g., Fig. 4C). Basement outcrops are highly variable

290 in size, and in seismic are characterized by low- to variable-

291 amplitude reflections that differ from the overlying

292 sedimentation patterns (Fig. 4D). These outcrops are more

293 abundant slightly lower in the slope where the gradient

294 decreases to 12-20 degrees. Basement is likely composed of

295 volcanics, as previously interpreted by Lort et al., 1979, and

296 Bassias et al., 2016.

$297 \quad$ 4.1.3 Escarpments 
299 surfaces may also be broken by escarpments and slope failure

300 scars. On the Glorieuses platform, a linear escarpment at a

301 water depth ranging between 700 and 850 meters is traceable

302 for approximately $70 \mathrm{~km}$ around the platform's perimeter (Fig.

$3034 \mathrm{~A}$ and inset). This escarpment is most prominent on the

304 northwest side of the platform, and reaches around 120 meters

305 in height with a slope of 50-80 degrees. It lies at the same

306 bathymetric depth as the small terrace to the northwest of the

307 main platform. Similar long, well-developed linear escarpments

308 are not seen on other platform slopes.

$309 \quad$ 4.1.4 Slope failure scars

310 Elsewhere, smaller, discrete scarps (c.f. Hampton and

311 Lee, 1996) are evident on several sites in the upper slope. On

312 Juan de Nova, multiple arcuate scarps 400-2000 m across incise

$31360-150 \mathrm{~m}$ into the upper slope surface (Fig. 5A-5B). At least 10

314 of these are present around the islands' perimeter, all of which

315 occur where the surrounding slope gradient ranges from $22^{\circ}$ -

$31628^{\circ}$. Arcuate scarps, however, are not distributed evenly; they

317 are more abundant on the windward south side of the platform,

318 with the leeward side having a quantitatively smoother, lower

319 rugosity slope (Fig. 5C). The morphology of scarps are also

320 different - scarps on the leeward slope generally have less

321 relief, on the order of 50-60 meters as opposed to 100 meters or

322 more on windward sides. As a first approximation, the volume 
of sediment once filling these scarps was calculated using a

324 series of three-dimensional wedges, based on the gradient

325 found above and below the scar in question (Table 1).

326 Individual scarp volumes range from approximately 1 to 10

$327 \mathrm{~km}^{3}$, with the caveat that true volumes are slightly smaller due

328 to their irregular shape (Fig. 5A, 5B), a factor not included in

329 the calculation. These small individual scarps are not present on

330 the slopes of other platforms; however, on Bassas da India a

331 scallop-shaped indentation on the platform top (4 km across;

332 see Fig.tre 6A) may also be the product of past slope failure on

333 a much larger scale. The slope just below this indentation is

334 highly rugose and is the source of channels that extend to the

335 basin floor. Large areas of erosion are also seen on the southern

336 side of Europa (Fig. 6B), but do not have the distinctive arcuate

337 morphology seen on Juan de Nova.

$338 \quad 4.1 .5$ Gullies and channels

339 Below the smooth uppermost slopes (greater than $20^{\circ}$ -

$34025^{\circ}$ ), mid-slope (from $20^{\circ}-25^{\circ}$ to $10^{\circ}$ ) and lower-slope $\left(0-10^{\circ}\right)$

341 zones contain a series of basement outcrops, linear

342 ehannelsgullies, and sedimentary deposits (Figs. 2 and 3). In

343 the mid-slope, gullies ehannels-incise into the basement

344 substrate (Fig 4D) and are separated by volcanic outcrops, but

345 are generally not deep or narrow enough to be considered

346 canyons, though the distinction is not based on quantitative

347 criteria (Hay, 2014). These gullies gradationally transition into 
348 true channels as the slope decreases. In seismic, channel floors

349 can be seen to be composed of high-amplitude, relatively

350 continuous reflections up to $\sim 85 \mathrm{~m}$ thick, but without a distinct

351 base (Fig. 4D). In map view, channels are generally straight,

352 with flat bottoms and walls generally between 40 and $100 \mathrm{~m}$

353 high (Fig. 4C), though this varies considerably. In lower slopes,

354 channels may erode into sediments rather than basement.

355 Further details of sedimentary deposits associated with

356 channels and their geomorphologic elements are discussed

357 below.

$358 \quad 4.2$ Sediments of the slope and proximal basin

359 4.2.1 Distribution

360 Most sediment in the Iles Eparses slopes accumulates in

361 the lower slope, where the gradient is less than $10^{\circ}$. Seismic

362 and bathymetric data reveal that lower slopes contain a wedge-

363 shaped sedimentary package wedge that extends to up to 30

364 kilometers from the platform top (Figs. 2, 3 and 7; seismic data

365 showing sedimentary nature of lower slope wedge-sediments in

366 Fig. 7A). Thiese sediments wedge is are elevated relative to the

367 generally flat basin floor (Figs. 2 and 3), and hasve a higher

368 gradient (usually $3^{\circ}-6^{\circ}$, vs. $0-3^{\circ}$ ). The change in slope gradient

369 marks the slope base; sediments beyond this point are

370 considered to be in the adjacent basin. Where bathymetric data

371 is available around the entire slope perimeter, lower slopes can

372 often be seen to have asymmetric distribution around the 
373 platform, with bathymetric highs occurring more prominently

374 on leeward sides of at least some platforms (especially in

375 Europa, Glorieuses, and Juan de Nova; see Figs. 2 and 3).

376 Representative slope profiles on windward and leeward sides of

377 the platforms are shown in Figure 7B-D. Although upper slopes

378 may similar or steeper on either side, in each instance the lower

379 slope wedge extends further from the platform top on the

380 leeward side.

381 4.2.2 Lithologies

$382 \quad$ Cores acquired on lower platform slopes (locations in

383 Figs. 2 and 3) reveal the character of sediments in the shallow

384 subsurface. A selection of representative core is shown in

385 Figure 8A-D, all of which consist predominantly of

386 foraminiferal muds-ooze interbedded with beds of unlithified

387 carbonate sandgrainstones, packstones, or wackestones.

388 Carbonate sand These coarser-grained carbonate beds make up

389 a minor but significant proportion of core thicknesses, usually

390 between $<1$ and $20 \%$. The dominant grain size in these beds is

391 generally fining-upward, with most constituent particles

392 earbonate sands ranging from fine-to medium-grainedless than

$393 \underline{0.5 \mathrm{~mm}}$ (Fig. 8E), although - many beds have a basal lag with

394 coarser skeletal fragments. Carbonate sediments within these

395 beds are unlithified and well-sorted ${ }_{2}$-earbonate grainstones or

396 packstones, without clear sedimentary structures other than

397 occasional horizontal laminae. The sand-sized component of 
of $100 \%$ calcareous material, including many taxa normally

400 found in the photic zone: coral and algal fragments, echinoid

401 spines, and well-preserved gastropods (Figs. 8F, 8G). The tests

402 of planktonic and benthic foraminifers also make up a

403 significant portion of these sands (up to $35 \%$ of identifiable

404 grains; Fig. 8F). Interbedded with these sediments are thicker

405 beds of sandy foraminiferal carbonate mudsooze., with the

406 sand-sized portion predominantly made up of benthic and

407 planktonic foraminifera. The clay-sized fraction of these

408 background micritic mudsmuds is not identifiable

409 petrographically, however, SEM images (Fig. 8H) reveal the

410 presence of needle-like crystals, as well as platy grains. EDS

411 analysis (Fig. 8H) shows that intervals dominated by needle-

412 like crystals are enriched in calcium and oxygen, suggesting a

413 carbonate mineralogy, whereas those dominated by platy grains

414 have elevated amounts of silicon, aluminum, and oxygen - all

415 elements that are components of phyllesilicate minerals. To

416 better understand the composition of this component of the

417 mud, XRD analysis was performed on a sample from the same

418 approximate interval (MOZ4-CS09, 100-102 cm). Results show

419 the presence of quartz, feldspar, and various clay minerals,

420 confirming the siliciclastic nature of some of these grains (Fig.

$4218 \mathrm{H})$.

422 4.2.3 Channels, lobes, and levees 
424 al., 2018),-evolve distally into channels that are traceable

425 through their increased reflectivity (backscatter) values (shown

426 in red in Figs. 2B, 2D, 3B, 3D, and 9A-9C). All lower slope

427 channels are extremely straight, with most sinuosities above

4280.9 , typical gradients between $5^{\circ}$ and $10^{\circ}$, and with walls that

429 range between $40-100 \mathrm{~m}$ above the channel floor. Like the

430 overall slope, the gradient of channels floors decreases steadily

431 basinward (see inset of Figure 4C, showing gradient decrease

432 from $\sim 30^{\circ}$ to $\sim 10^{\circ}$ over the course of $5 \mathrm{~km}$ ). In map view, most

433 channels originate in the upper slope and continue downslope

434 to reach the basin floor. Areas of increased backscatter intensity

435 often taper basinward to a point (e.g., Fig. 9A), although

436 channel forms may be seen in bathymetric relief to continue

437 further downslope. In several places, however, an individual

438 upper slope incised channel splits into multiple channels in the

439 mid-slope (e.g., the eastern side of Europa, denoted by an arrow

440 in Fig. 2D, and the northeastern side of Bassas da India; Fig.

441 9B). This point of channel bifurcation most often occurs where

442 the slope gradient decreases to around $10^{\circ}$. The lower slope

443 channels that radiate outward from this point are smaller and

444 also straight, and often reach the basin floor. On the

445 northwestern side of Glorieuses, some slope channels contain a

446 regularly-spaced series of escarpments, 450-750 m apart and 
15-60 $\mathrm{m}$ high_, resembling eyclic stepsthat form an undulatory

448 topography within the channel (Fig. 9B).

On the northern side of Europa, at least one lower slope

450 channel is bounded by a-well-defined raised sedimentary

451 deposits with a 'bird-wing' shape in cross-sectionasymmetric

452 levee, seen in seismic data in Figures 9D and 9E and

453 interpreted as a levee deposit. These deposits tevee-and the

454 channel axis are visible in bathymetric data as well, though the

455 channel itself shows no increased backscatter values. In

456 seismic, levee deposits are transparent with faint, but

457 continuous, reflections (Facies E, described below), and - - reach

458 a maximum thickness of 280 meters in the seismic profile

459 shown in Fig 9D. Height from the channel floor to the highest

460 part of the levee is 70 meters or less. The central channel floor

461 is characterized by higher amplitude reflections, as are the

462 deposits several kilometers beyond the levee boundaries. Levee

463 deposits eventually merge into transparent, furrowed sediments

464 on the basin floor, shown on the right side of Figure 9D and

465 visible in on the seafloor in Figure 3C (labeled). A 27-m core

466 (MOZ4-CS23; see portion in Fig. 8D) taken directly atop the

467 levee shown in Figure 9D and 9E consists almost entirely of

468 foraminiferal carbonate mud, with carbonate sand beds

469 occurring only near its base.

470 Channels may terminate in a fanlobe near the bottom of

471 the lower slope or on the basin floor, although fans-lobes are 
472 not always present. A distinct fan-lobe (visible in backscatter

473 imagery; Fig. 9C) on the northeastern side of Bassas da India

474 was selected for more detailed investigation and was penetrated

475 sampled by core MOZ1-KS27 (Fig. 8A). The fan-lobe is

476 approximately 4 kilometers across at its widest visible point, is

477 estimated to range from 0 to tens of meters thick based on

478 seismic data, and begins where the slope gradient is around $3^{\circ}$.

479 Core MOZ1-KS27 (Fig. 8A), despite only being $4 \mathrm{~m}$ long,

480 contains multiple lithofacies indicative of the fanlobe's

481 composition. Above background foraminiferal muds, a $\sim 30-\mathrm{cm}$

482 thick bed with a sharp lower surface contains a basal layer of

483 large (10-15 mm) coral and algal fragments within a matrix of

484 very coarse, bioclastic calcareous sandgrainstone. This coarse

485 skeletal grainstone facies is overlain by a one-meter thick unit

486 of muddy-carbonate sand-packstone-wackestone (dominant

487 grain size around $0.3 \mathrm{~mm}$ ) that contains irregular clasts of mud

$488 \quad 2-20 \mathrm{~cm}$ in diameter, which roughly increase in size upward

489 through the unit. This facies is in turn overlain by a $20-\mathrm{cm}$

490 thick, well-sorted, fining-upward bed-of sands, containing fine-

491 to medium-grained carbonate grainstones ealcareous sands

492 (Fig. 8E) with a similar composition to those seen elsewhere.

493 4.2.4 Subsurface seismic facies

494 Seismic lines acquired on the lower slopes and proximal

495 basins of Iles Eparses platforms show several distinct types of

496 sedimentary deposits, which can be classified based on the 
497

498

499

500

501

502

503

504

505

506

507

508

509

510

511

512

513

514

515

516

517

518

519

520

amplitude, continuity, and orientation of their internal reflections (Table 2). Seismic facies are found in different locations surrounding each platform, and not all facies are present surrounding each locality.

Sediments comprising the basin floor are typically characterized by horizontal to sub-horizontal, continuous, highamplitude reflections that extend to the outer limits of seismic data (Facies A; Figs. 10 and 11) and that onlap onto the lower slopes of platforms. These are seen in all seismic lines that intersect the basin floor. On the eastern side of Juan de Nova, $\underline{\text { sSediments of this facies originateing from the Madagascar }}$ shelf-depesit and form thick, laterally continuous sediment packages into the basin, separated by clearly identifiable onlap surfaces (Figs. 10BC, 11B10D). Here, this facies interfingers with Facies B (transparent, chaotic reflections; Fig. 10B10C), $\underline{\text { which }}$-is contained within discrete units that taper away from the Juan de Nova platform. interfingers with sediments coming from the incised continental slope of western Madagascar.

Sediments riginating from the Madararear shelf deposit thick, taterally continuous sediment packages into the basin, separated by clearly identifiable onlap suface (Figs. 10B, 11B). These sSubsurface units originateing from the JDN platform (e.g., these identified inFig. 11B10D), are 30-40 m thick, and extend seven or more kilometers into the basin. Internal character in

521 these units is consistently transparent and shows little proximal- 
distal evolution. On the northwestern side of the Glorieuses

523 platform, chaotic, transparent Facies B is present in dip line 315

524 around $120 \mathrm{~m}$ below the seafloor surface (Fig. 11A $10 \mathrm{C}$,

$52511 \mathrm{C11 \textrm {B }})$. Here, the unit containing Facies Bthis facies extends

526 only $\sim 2 \mathrm{~km}$ away from its origin point, forming a thicker,

527 shorter seismic unit that is laterally adjacent to Facies D

528 (discussed below).

529 In Bassas da India, a large, amalgamated unit of Facies C

530 (chaotic facies of mixed amplitude) makes up a significant

531 portion of the subsurface on the northeastern side of the island

532 (Figs. 10A, 11A $\underline{10 \mathrm{~B}}$ ). The deposit sits directly atop basement,

533 and decreases in thickness over the course of approximately 15

$534 \mathrm{~km}$. This unit shows little interfingering with adjacent

535 hemipelagic basinal sediments; up to 320 meters of flat basin

536 sediments unconformably onlap the unit. Internally, this unit

537 contains at least one strongly reflective basement-parallel

538 surface, and contains both high- and low-amplitude chaotic

539 reflectioners.

540 Units containing both the chaotic reflections of Facies C

541 and the more organized reflections of Facies D are present

542 within discrete units on the northwestern side of Glorieuses in

543 dip lines 315 and 319 (Figs. 10C $\underline{11 \mathrm{~A}}, \underline{11 \mathrm{~B}, 10 \mathrm{D} 12}, 11 \mathrm{C}$ ). The

544 most prominent unit containing these facies, up to $\sim 80 \mathrm{~m}$ thick,

545 forms a wedge-shaped sediment package (Facies $D$-described

546 above) extending approximately $12 \mathrm{~km}$ basinward from its 
547 origin point on the lower slope. In this unit, seismic Facies D

548 contains both platform-and basinward-dipping high-amplitude

549 reflections. Reflections in this unit become thinner and

550 increasingly horizontal, ultimately terminating into the

551 continuous, high amplitude, 'railroad tracks' that make up

552 Facies A in the deep basin away from platforms. Just to the

553 northwest of this line, a different unit containing organized,

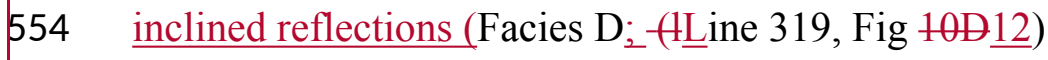

555 comprises a significant portion of the subsurface, forming an

556 irregular unit that tapers basinward and is not well-separated

557 from the underlying sediments. In this areaunit, the seafloor

558 surface contains a series of irregular, arcuate or linear ridges

559 that are $10 \mathrm{~s}$ to $100 \mathrm{~s}$ of meters in relief with $25-50 \mathrm{~m}$ amplitudes

560 (decreasing basinward), and wavelengths of 700-1200 m (Fig.

$56110 \mathrm{D}$ 12). Seismic Line 319 crosses these ridges, and shows that

562 they are the surface expression of concave-downward seismic

563 structures that originate deeper in the subsurface. These

564 structures are characterized by a series of high-amplitude

565 reflections that dip back toward the platform and gradually

566 become tangential to a subhorizontal surface approximately

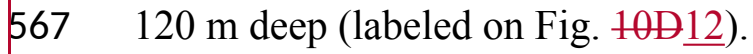

568 Facies E (Fig. 6A9D) is seen on the northern side of

569 Europa in the birdwing-shaped levee and channel deposits that

570 make up the lower slope. Reflections in this facies are mostly

571 continuous and low amplitude, though amplitude and continuity 
572 are somewhat variable across the observed deposit. In strike

573 line 015 (Fig. 9D), reflections within the levee are parallel to

574 each other and to the seafloor surface. In dip profile (Fig. 7A)

575 this facies can be seen to grade into horizontal, parallel

576 reflections on the basin floor, which increase in amplitude

577 basinward to conformably become Facies A (Table 2).

578 5. Discussion

$579 \quad 5.1$ Interpretation of sedimentary deposits

$580 \quad 5.1 .1$ Facies diversity

581 Cores reveal that deposits on the slopes and in the

582 proximal basins surrounding platforms are a combination of

583 pelagic and platform-derived sedimentation. Within muddy

584 deposits, clay minerals (Fig. 8H) are likely the product of

585 weathering, suspension and transport of clastic sediments in

586 seawater, and subsequent deposition through pelagic rain

587 (Facies G of Pickering et al., 1986). These lithologies are

588 present in all cores and may originate from the African

589 continent (Kolla et al., 1976; Wiles et al., 2017), or-Madagascar

590 (the nearby Betsiboka River exports large volumes of fine-

591 grained sediment; Raharimahefa and Kusky, 2010), or

592 elsewhere. While the carbonate platforms discussed here are

593 themselves unlikely to generate significant amounts of

594 aluminosilicate clays found in seafloor muds, the submarine

595 weathering of basalt and other volcanics can produce smectite

596 and other clay minerals (Kolla et al., 1976) and thus may be the 
597 origin of some of the sediment seen here. Coccoliths and

598 planktonic forams also form a significant portion of the fine-

599 grained background sediment - these too are the result of

600 pelagic rain, and may also have been transported long distances

601 (van Sebille et al., 2015). Aragonite needles found in some

602 samples are produced in shallow water on or near carbonate

603 platforms (Milliman et al., 1993). This aragonite is therefore

604 interpreted to have been winnowed from the platform top

605 during times of flooding, as has been hypothesized by Jorry et

606 al (2016).

607 Coarser-grainstone-packstone ed (sand-dominated and

608 above) -units found in core also show evidence of a nearby

609 shallow-water origin. Bioclastic grains (e.g., corals and

610 calcareous algae) are the skeletal remains of organisms that live

611 primarily within the photic zone; they provide unambiguous

612 evidence that at least part of the sediments forming these beds

613 are allochthonous, and come from the tops of nearby platforms.

614 The exact process by which sediment is transferred off of the

615 platform top is unknown, however, wind-related or tide-related

616 currents are both however, winds, currents, and tidal forces are

617 allactive on the shallow water portion of platforms. Elsewhere,

618 density cascading has been proposed as a mechanism for the

619 off-platform transfer of sediment (Wilson and Roberts, 1995), a

620 process which is not likely to be may also be-active here as it is 
621 dependent on winter cold fronts that are not present in the

622

623

624 those shown in Fig. 8A-E) areis consistent with deposition as

625 turbidites (Shanmugam, 2000). Other depositional processes

626

627

628

629

630

631

632

633

634

635

636

637

638

639

640

641

642

643

644 is a combination of hemipelagic sedimentation and gravity flow

645 deposits. However, larger-scale sediment transport processes 
646 are also operating on platform slopes, as depositional units seen

647 in seismic profiles show evidence of mass transport on a

648 kilometer scale.

$649 \quad 5.1 .2$ Subsurface expression

650 Sedimentary units and associated facies seen in seismic

651 lines and bathymetric data are interpreted to consist of three

652 primary types of deposits:

653 - Basin floor pelagites

654 - Mass transport deposits (MTDs)

655 - Channels, levees, and fans/turbidite lobes

656 High-amplitude, parallel reflections on the basin floor

657 (Facies A) are interpreted to be the result of pelagic and

658 hemipelagic sedimentation processes that are continually

659 occurring in the deep sea (Pickering et al., 1986). This seismic

660 facies corresponds to the foraminiferal muds that are seen in

661 core. Thin carbonate turbidites may also be present within this

662 facies, but are likely to be only in the area immediately

663 surrounding each platform. Near Juan de Nova, the character of

664 these background sediments is more variable than elsewhere

665 (Fig. 10B10C); this is likely a result of their proximity to the

666 western slope of Madagascar. Here, the variety of slope-related

667 sedimentary processes creates internal surfaces and topography

668 not seen in the abyssal basin floor elsewhere (Fig. 11B10D).

669 Seismic Facies B-C, characterized by low- or mixed-

670 amplitude chaotic reflections, -are usually restricted to discrete 
671 units and contain many of the criteria used to recognize mass

672 transport deposits (MTDs), as outlined in Posamentier and

673 Martinsen (2011). Based on the geometry of the unit, as well as

674 the amplitude, continuity, and the orientation of internal

675 reflections, these MTDs are interpreted to be the result of one

676 of several depositional processes. MTDs consisting of chaotic,

677 transparent reflections (Facies B) and those with chaotic, but

678 higher amplitude reflections (Facies C) are interpreted to be the

679 result of submarine debris flows originating on the platform

680 slope. Deposits with similar chaotic seismic character have also

681 been referred to as debris flows by Carter (2001), Posamentier

682 and Kolla (2003), and Joanne et al. (2013), among others. In

683 carbonates specifically, Principaud et al. (2015) interpret

684 chaotic seismic units as mass transport complexes with a debris

685 flow component, and Janson et al. (2011) interpret units

686 characterized by discontinuous, low-amplitude reflectionslso

687 interpreted as debris flows. among others.Debris flow

688 processes remove original stratification during downslope

689 movement, and have the potential to travel long distances

690 (Mulder and Cochonat, 1996), features consistent with the units

691 seen here that extend for several kilometers. The amplitude of

692 the reflections that distinguishes between these facies is likely a

693 product of the lithologic heterogeneity of the source material.

694 On the eastern side of Juan de Nova, this facies contains large

695 stratified and convolute-bedded blocks on a scale of several 
696 hundred meters (Fig. 10B 10C), interpreted as large blocks of

697 coherent or deformed sediment entrained within the mass

698 movement

699 The basinward or platform-dipping reflections in some

700 units containing Facies D suggest that a different process is

701 responsible for their deposition. A unit on the northwestern side

702 of Glorieuses thins basinward and displays both progradational

703 and retrogradational internal geometries (Figs. 10 $\underline{\mathrm{C} 11 \mathrm{~A}}$,

$70411 \mathrm{C} 11 \mathrm{~B})$. This unit is interpreted as a turbidite lobe, as deposits

705 with these types of geometries have been interpreted elsewhere

706 as turbidites (e.g., Gervais et al., 2006). It is likely the

707 subsurface expression of the type of lobate fansdeposits seen on

708 the current seafloor elsewhere (e.g., on Bassas da India; Fig.

709 8A). On the northwestern side of Glorieuses, the unit seen in

710 Figure 10D-12 contains a series of organized structures with

711 platform-dipping reflections that are expressed on the seafloor

712 surface. These deposits are interpreted as a large MTD with

713 depositional thrusts and pressure ridges (Fig 10D12) gliding

714 along a subsurface decollement. Such features are known to

715 form due to the compressional regime encountered during some

716 downslope mass movements (Posamentier and Martinsen,

717 2011; Alsop et al., 2017), however, this is one of the first times

718 they have been clearly documented in a predominantly

719 carbonate system. Sedimentary compression ridges similar to

720 these have been noted in analogous settings in the clastic 
721 realm - nearly identical features are described in recent,

722 submarine sediments from multiple locations (e.g., Alfaro and

723 Holz, 2014; Moscardelli et al., 2006; Frey-Martínez et al.,

724 2005; Hampton and Lee., 1996; Joanne et al., 2013).

725 Compressional features cannot explain all seafloor ridges near

726 Glorieuses, however; smaller sediment waves are also present

727 in the same area, and some of the seafloor topography seen in

728 Figure 2A may be related to turbidity currents.

729 Transparent, continuous Levee deposits in Facies E are

730 form a channel levee, and interpreted to be the result of the

731 overbank depositional processes associated with channelized

732 sediment gravity flows. The generally low-amplitude nature of

733 these deposits suggests that they are of uniform composition

734 and fine-grained, an interpretation confirmed by the

735 predominance of muds in core MOZ4-CS23 (Fig. 8D).

$736 \quad 5.1 .3$ Seafloor surface

737 Backscatter (reflectivity) data has been reliably shown to

738 predict sedimentological facies (Dartnell and Gardner, 2004),

739 grain size (Clarke et al., 1996; McGonigle and Collier, 2014),

740 and degree of induration of the seafloor (Mulder et al., 2017),

741 though has not been used previously to differentiate between

742 carbonate sands and muds. Here, high reflectivity values are

743 interpreted to denote areas of submarine volcanism, erosional

744 outcrops, and active sediment transfer where coarser-grained

745 (larger than silt-sized), facies are more abundant on the 
746 seafloor. This assumption fits with observed geomorphology

747 and is preliminarily confirmed by core data. Backscatter data

748 shows that active deposition of coarse-grained material is

749 currently taking place through feeder channels that funnel

750 sediment to the basin floor (Figs. 2 and 3). High reflectivity

751 values are interpreted to be the result of carbonate sands

752 (grainstones) on the floors of incised channels, which respond

753 differently to acoustic soundings than surrounding muds.

754 Although lithified volcanic outcrops are also highly reflective,

755 these are easily distinguished from linear sediment pathways.

756 High-reflectivity sediments within channels may terminate on

757 the basin floor in a lobeate fan, and channel forms may be

758 bounded by elevated levees (Fig. 9 $\underline{\text { D-E) }}$. Undulatory surface

759 morphologies within some channels are interpreted as cyclic

760 steps (c.f. Covault et al., 2017) $\div$-These types of bedforms,

761 lobefans and levees are associated with deposition from

762 turbidity currents (Shanmugam, 2000), and this is interpreted to

763 be the primary process of sediment transfer from the platform

764 top. Channel forms without increased reflectivity are

765 interpreted as inactive, as is the case in the leveed channel

766 noted in Fig. 9C. This channel and others like it may have been

767 cut off from active deposition in the past, a hypothesis

768 supported by the lack of recent sandy deposits in the adjacent

769 core (MOZ4-CS23). Individual channels may therefore have a 
770 finite lifespan, and active channels and lobes may switch with

771 changes in sediment availability.

7725.2 Controls on deposition and geomorphology

773 The nature of the volcanic edifice underlying each

774 platform ultimately influences the size, height, and overall

775 gradient of the slope profile, all of which influence the slope

776 depositional architecture. Volcanic cone morphologies lead to

777 an overall smaller platform top size, limiting the volume of

778 bioclastic carbonate sediment that can be produced and thus

779 reducing the available sediment supply to slopes. High

780 gradients in the upper slope lead to little carbonate deposition;

781 the majority of slope sedimentation takes place where gradients

782 are less than $10^{\circ}$. This upper slope bypass inhibits progradation

783 and lateral expansion of the platform top. Slope steepness is

784 also likely responsible for straight channel morphologies (Clark

785 et al., 1992) and the development of basin-floor fan_systems, a

786 type of deposit rarely seen in modern carbonate settings

787 (Payros and Pujalte, 2008). The abundance of MTDs on the

788 lower slope and proximal seafloor may also be influenced by

789 slope steepness, although past studies (e.g., Hühnerbach and

790 Masson, 2004) note that the number of slope failures are is

791 relatively independent of inclination, even in volcanic islands.

792 Active regional tectonics may also directly influence platform

793 morphology (and thus deposition), as in the fault-generated

794 subaqueous terrace on Bassas da India. Processes occurring on 
795 the terrace may likely affect the sedimentary character of

796 platform sediments; large sand dunes (Fig. 4B, inset; lithology

797 confirmed by sediment samples) suggest that sediments may be

798 winnowed and transported by bottom currents atop the terrace

799 before subsequently moving further downslope.

800 The direction and intensity of dominant trade winds have

801 long been known to have an effect on the facies distribution on

802 carbonate platforms (Dravis and Wanless, 2017) including on

803 Glorieuses (Jorry et al., 2016; Prat et al., 2016). In the Iles

804 Eparses, most platform tops show some degree of wind-related

805 asymmetry, especially on Glorieuses and Juan de Nova.

806 Platform tops also differ in terms of their geomorphology,

807 which likely has some influence over the nature and

808 distribution of slope sediments. Open platform tops without a

809 fringing reef (Glorieuses and Juan de Nova) have a submarine

810 bank with no barriers between the top and slope break, a

811 morphology that promotes continuous deposition and sediment

812 transfer (Fig. 2). Enclosed platform tops (Bassas da India) have

813 an interior lagoon with a mostly continuous fringing reef,

814 preventing continual transferal of large amounts of sediment

815 from the inner platform to the slope, and possibly affecting the

816 sedimentological character of platform top exports by confining

817 platform-top muds (Fig. 3). On the top of Europa, sediment

818 transfer is localized, showing a strong directionality to

819 sediment export in the form of a wide tidal channel. This 
820 channel is clearly the origin point for the largest single channel

821 on the slope (labeled 'TC' on Fig. 4C). However, backscatter

822 data (Fig. 3D) do not suggest that active sedimentation is

823 appreciably increased within this specific channel axis when

824 compared to the many other channels visible surrounding the

825 island. Future studies of platform top sedimentology are needed

826 to fully understand the way that sediment export is affected by

827 platform top elements.

828 Wind-related asymmetry extends to the slope as well-

829 the leeward sides of carbonate platforms elsewhere have been

830 established to have their morphology affected by off-platform

831 sediment transport (e.g., Hine et al., 1981). Here, leeward sides

832 are generally smoother, with fewer high-relief outcrops. This is

833 interpreted to be a product of increased sedimentation, which

834 would promote faster erosion of any volcanic highs or remnant

835 sedimentary outcrops, and would infill depressions and low

836 areas with sediment. Windward sides of platforms are

837 sometimes more rugose than leeward sides. This can also be

838 attributed to increased abundance of outcrops of underlying

839 basement, as well as from steep-sided arcuate slope failures.

840 Decreased windward sedimentation may lead to oversteepened,

841 sediment-starved windward slopes, which are more prone to

842 failure.

8435.3 Summary and facies model 
845 from an idealized scenario, the character and distribution of

846 sedimentary facies seen here is significantly different from

847 previously established models of carbonate slopes elsewhere.

848 Past models have generally not focused on steep, volcanic-

849 cored platforms, however, these settings are clearly responsible

850 for the generation of substantial amounts of carbonate

851 sediment, and have a unique set of depositional features when

852 compared to those elsewhere. The geomorphology, depositional

853 elements, and sedimentary processes seen in the Iles Eparses

854 are synthesized in a facies model shown in Figure $12 \underline{13}$.

855 In summary, sediment transfer to the deep sea in the Iles

856 Eparses is a combination of processes at a variety of scales.

857 Carbonate sediments on the platform top are transported onto

858 the broad, steep upper slope through the action of wind- or tide-

859 generated water movement, shallow currents, or density

860 cascading (Fig. $124 \underline{13 \mathrm{~A}}$ ). The slope becomes increasingly

861 channelized basinward, with sediments moving down straight

862 channel axes in gravity flows. Sands-Carbonate grainstones-

863 packstones are ultimately deposited in the lower slope or

864 proximal basin in the form of gravity flow deposits (turbidites

865 and debrites), including levee and overbank deposits, where

866 they are interbedded with hemipelagic foraminiferal muds.

867 These interbedded gravity flow deposits and background muds

868 (and possibly basement volcanics) may move further 
869 downslope together in the form of large-scale mass transport

870 deposits that originate on the slope itself (Fig. 12B13B). MTDs

871 may in turn be subsequently reworked as new channels incise

872 into lower slope sedimentary deposits (Fig. 12C13C). Any

873 given slope deposit may therefore be the result of multiple

874 sedimentation processes, and a range of depositional elements

875 resulting from several different processes may be present on the

876 seafloor at any given time. Figure $12 \underline{13}$ shows a composite

877 sketch combining many of the observed geomorphologic and

878 depositional features seen across platforms, and general

879 characteristics are summarized in the chart in Table 3.

8805.4 Implications

881 The synthesis of observed features and processes shown

882 in Figure $12 \underline{13}$ is one of the first detailed facies models for

883 sedimentary deposition on the slopes of carbonate atolls and

884 atoll-like carbonate platforms. It can be compared with similar

885 block diagrams on other carbonate slopes (e.g. Betzler et al.,

886 2014, Grammer and Ginsberg, 1992, Mulder et al., 2017,

887 Mullins and Cook, 1986, Mullins et al., 1984, and Payros and

888 Pujalte, 2008, among others). Although these are very different

889 types of carbonate platforms from those discussed here, such a

890 comparison is essential in determining which aspects of

891 carbonate deposition are more universal, and highlights the

892 differences between the settings discussed here and more

893 'traditional' carbonate platforms. In addition, facies on the 
894 slopes of these platforms differ from those on other volcanic

895 islands. The island of La Réunion (Indian Ocean), for example,

896 is characterized by a steep-sided central volcanic cone rather

897 than a flat, carbonate-dominated platform top. Facies models

898 developed on the submarine slopes of La Réunion therefore

899 lack the extensive carbonate deposits seen here, and are instead

900 dominated by large-scale flank collapses, lava flow platforms

901 and deltas, and volcaniclastic fan systems (Babonneau et al.,

902 2011; Saint-Ange et al., 2013; Sisavath et al., 2011).

903 Elsewhere, the flanks of Madeira Archipelago (a series of

904 volcanic islands in the Atlantic Ocean) are also dominated by

905 numerous large, arcuate slope failures, as well as numerous

906 radial gully-channel systems more similar to those seen here

907 (Quartau et al., 2018). These channels, however, often show a

908 well-developed dendritic pattern in map view, and coalesce into

909 longer, larger channels that extend much further from the

910 islands than those in the Iles Eparses.

911 Of note in the Iles Eparses are the presence of clear,

912 unambiguous channel systems with lobate basin-floor fans.

913 This type of lobate fan system has rarely been described in

914 other modern carbonate settings: Payros and Pujalte (2008)

915 state that "Calciclastic submarine fans are rare in the

916 stratigraphic record and no bona fide present-day analogue has

917 been described to date." Mullins and Cook (1986) also note the

918 paucity of unambiguous examples in the geologic record, and 
919 James and Jones (2016) note that submarine fans do not

920 typically form on carbonate slopes because of the linear, rather

921 than point-sourced, nature of slope profiles. Terminal fans seen

922 in the Iles Eparses are likely present because sediments are

923 concentrated into relatively few active channels that reach the

924 basin floor. Platform-derived sediment is distributed over a

925 relatively small area, resulting in more focused distributary

926 systems and promoting point-sourcing of deposition.

927 Although the deposits seen here are relatively recent in

928 origin, the distribution and character of these sediments may be

929 used as an analog for deposits elsewhere. Core taken on lower

930 slopes almost always include some component of eoarse-

931 grained carbonate sandsgrainstones-packstones, a facies with

932 more potential as a conventional hydrocarbon reservoir than the

933 periplatform muds that make up the majority of core in inter-

934 channel areas, MTDs, and levees. Goldstein et al. (2012) note

935 the difference in reservoir potential between dispersed- and

936 focused-flow carbonate slope systems in the Miocene of Spain;

937 the Iles Eparses deposits are more similar to the latter. These

938 types of small isolated platforms therefore have a different

939 reservoir potential and sediment distribution than other, larger

940 platforms with more dispersed depositional systems. The higher

941 reservoir potential of more concentrated focused-flow

942 grainstones should be tempered by the overall smaller volume,

943 smaller distribution radius, and lower preservation potential of 
944 these types of settings; the geologic record of atolls and

945 carbonate platforms atop deep sea volcanoes is relatively

946 sparse.

947 6. Conclusions

948 The Iles Eparses atolls, islands, and platforms are situated

949 on isolated deepwater volcanic pedestals in and around the

950 Mozambique Channel, making them genetically different from

951 other, more well-known carbonate settings. This study provides

952 a first look into the nature of carbonate slope sedimentation in

953 this unique, little-known depositional environment, and

954 presents the first detailed facies model for the types of atoll and

955 atoll-like platforms discussed here. Slope sediments are a

956 product of a range of gravity-dominated depositional processes,

957 including hemipelagic rain, slope failure and downslope mass

958 transport, and gravity flows (turbidites and debrites). Inherited

959 topography of the underlying volcanic pinnacles results in steep

960 upper slope gradients where little sedimentation takes place and

961 arcuate slope failure scars are locally common. Platform-

962 derived carbonates may be channelized in the lower slope,

963 forming, in places, relatively straight channel systems that

964 extend for tens of kilometers and may terminate in basin-floor

965 fanslobes, a relatively rare occurrence in modern-day carbonate

966 settings. Elsewhere on the lower slope, turbidites and mass

967 transport deposits are present, with the subsurface seismic

968 facies often taking the form of chaotic units interpreted as 
969 debris flows. Depositional thrusting and associated pressure

970 ridges are also present in some lower slope deposits. Slopes are

971 usually asymmetric with respect to predominant wind direction,

972 with leeward slopes usually having a lower rugosity than

973 windward slopes and more spatially extensive toe-of-slope

974 deposition. The lack of data in settings analogous to the Iles

975 Eparses underscores the need for further research, and shows

976 the importance of the observations reported here in expanding

977 the known spectrum of depositional carbonate depositional

978 environments.

979 7. Acknowledgements

980 The oceanographic expeditions PTOLEMEE, PAMELA-

981 MOZ1 and PAMELA-MOZ4 and Elda Miramontes' fellowship

982 were co-funded by TOTAL and IFREMER as part of the

983 PAMELA (Passive Margin Exploration Laboratory) scientific

984 project. This work was supported by the "Laboratoire

985 d'Excellence" LabexMER (ANR-10-LABX-19) and co-funded

986 by a grant from the French government under the program

987 “Investissements d'Avenir". Thanks to Joseph Ronzier for

988 writing and executing the Python script used in calculating

989 slope rugosity. Thanks to Simon Courgeon and Joseph Ronzier

990 for additional data contributions and helpful discussions related

991 to this project, Sandrine Cheron and Audrey Boissier for XRD

992 analysis, and Nicolas Gayet for SEM assistance. We also thank 
993 the captains and crews of the RVs Atalante and Pourquoi Pas?

994 during the cruises where this data was collected.

995

996 
997 Figure Captions

998 Table 1: General dimensions and associated volumes of

999 selected slope failure scars on Juan de Nova. Wedge diagram

1000 shows conceptual method of volumetric calculation.

1001 Table 2: Interpreted seismic facies found in lower slopes and

1002 proximal basins. Interpretations are based on the amplitude,

1003 orientation, and bounding relationships of seismic reflectors

1004 within seismic units.

1005 Table 3: Chart summarizing scale and character of selected

1006 depositional elements observed in this study.

1007 Figure 1: A) Location map of platforms and other geographic

1008 and geologic features mentioned in this paper. Oceanic

1009 circulation from Brietzke et al. (2017). COM-Comoros Islands;

1010 MAY-Mayotte Island; GLO- Glorieuses Islands; JDN-Juan de

1011 Nova; DR-Davie Ridge; ZV-Zambezi Valley ; BDI-Bassas da

1012 India; EUR-Europa. B) Present-day dominant wind directions

1013 from Metéo France, sourced from over 5000 individual

1014 measurements from weather stations on the islands. Bassas da

1015 India has no weather station, but is situated close enough to Ile

1016 Europa that wind directions are not appreciably different (see

1017 location in Figure 1A).

1018 Figure 2: Detailed bathymetric and backscatter maps of slopes

1019 of Iles Eparses platforms Glorieuses (A, B) and Juan de Nova

1020 (C, D). Bathymetric maps are an overlaid combination of

1021 absolute seafloor depth (color) and slope gradient (greyscale), 
1022 allowing both the slope relief and seafloor topography to be

1023 seen. Reflectivity maps use an arbitrary, sliding-scale color bar

1024 to best differentiate sedimentological and geomorphologic

1025 features. GG-Grande Glorieuse Island.

1026 Figure 3: Detailed bathymetric and backscatter/reflectivity

1027 maps of slopes of Iles Eparses platforms Bassas da India and

1028 Europa. Same parameters as Figure 2. A, B) Bassas da India; C,

1029 D) Europa, TC-tidal channel.

1030 Figure 4: Three-dimensional views of submarine platform

1031 slopes, focusing on slope morphology. Color gradient adjusted

1032 for each platform. A) Southeast-looking view of Glorieuses,

1033 showing the platform top, Glorieuses terrace and the linear

1034 escarpment most prominent on the northwestern side

1035 (magnified view in inset). B) Northward-looking view of

1036 Bassas da India, showing large submarine terrace and its profile

1037 and associated features, notably sand dunes and gullies found

1038 on the terrace surface in 350-600 meters water depth (insets).

1039 C) Southeastern-looking view of Europa, showing strike and

1040 dip profiles and location of seismic line in Figure 4D. Channel

1041 floor visible in both bathymetric and seismic data marked with

1042 an asterisk. Also of note is the steep, smooth upper slope

1043 surface, visible here on the leeward side of the platform. D)

1044 Europa seismic line 076 (PTO-mig076_v1500_g0). This line

1045 shows the relatively thin nature of sedimentary deposits in the 
1046

1047 the higher-amplitude reflections in channel floors.

1048 Figure 5: A-B): Evidence of slope failure on Juan de Nova; A)

1049 Leeward slope, showing generally smooth upper slope surface

1050 and two large arcuate scarps, denoted 1 and 2 in Figure 5D. B)

1051 Windward slope, with several discrete scarps highlighted

1052 (numbers 3-6). Approximate volumetric calculations for each

1053 numbered scarp shown in Table 1. C) Quantitative rugosity

1054 analysis of Juan de Nova upper slope. $1^{\text {st }}$ part shows conceptual

1055 method of quantification, second part applies the same method

1056 to the 600-m contour on Juan de Nova platform. On Juan de

1057 Nova, the windward side of the platform is significantly more

1058 rugose than the windward side.

1059 Figure 6: Examples of slope failure and/or erosion on Bassas

1060 da India and Europa, with along-strike profiles and dimensions.

1061 Figure 67: A) Seismic line 079 (PTO-mig079_v1500_g0),

1062 taken along the leeward side of Europa, showing sedimentary

1063 nature of the lower slope-wedge. The line is an oblique dip line,

1064 crossing channels and levees seen in Figures 8D and 8E, and

1065 clearly showing their contact with the underlying basement. B-

1066 D) Bathymetric profiles for the windward and leeward slopes

1067 of platforms. Bassas da India not included due to lack of data

1068 coverage on the windward side. Note extended lower slope on

1069 each leeward side; windward slopes often have a steeper

1070 descent to the basin floor. 
1071 Figure $7 \underline{8}$ : Core data from the lower slopes and proximal basins 1072 of Iles Eparses. Exact locations of core shown in Figure 2. A-

1073 D) Lithologies and core photos from four seafloor piston cores.

1074 Core MOZ4-CS23 (D) contains an additional 23 meters above

1075 the selected section that is almost entirely composed of

1076 background foraminiferal mudsooze. (A) taken at $3089 \mathrm{~m}$; (B)

$10773167 \mathrm{~m}$; (C) $1909 \mathrm{~m}$; (D) 2852 m. E) Grain-size profiles of the

1078 carbonate sand grainstone-packstone beds marked in red in

1079 above logs. F) Compositional data for selected intervals within

1080 carbonate sand-grainstone-packstone beds. Locations denoted

1081 in A-D. Data shown only includes identifiable grains;

1082 unidentified grains constitute $30-40 \%$ of total grains observed.

1083 G) SEM images of carbonate sands-grainstones in core MOZ1-

$1084 \mathrm{KS} 04$, interval 649-650 m, at the base of a relatively thick

1085 carbonate sand unit. Abbreviations: BF-benthic foraminifer;

1086 CA-calcareous algae; Ec-echinoid; Fo-Foraminifer; Ga-

1087 gastropod; PF-planktonic foraminifer. H) Analysis of

1088 muds/foraminiferal oozes; left side: SEM images; AN-

1089 aragonite needles; CM-clay minerals; Co-Coccolith. Right side:

1090 EDS spectra and XRD mineralogy of selected intervals.

1091 Figure 89: Examples of channels and channel-related features

1092 on Iles Eparses slopes. A) Reflectivity map of northeastern side

1093 of Glorieuses, showing numerous sub-parallel active channels

1094 that do not terminate in lobate fan-structures. B) and C) are

1095 overlays of reflectivity and slope data; B) Northwestern side of 
1096 Bassas da India, showing bifurcating channels, some of which

1097 terminate in a lobeate fan. Image is an overlay of reflectivity

1098 and slope data. C) Northern side of Europa. Inactive channel

1099 crossed by seismic lines in D and E is outlined with dashed

1100 line. Other, active channels have higher backscatter values and

1101 fan outward at the slope base. D) Seismic strike line on the

1102 north side of Europa showing channel-levee complex. Note

1103 levee transparency, higher-amplitude asymmetric overbank

1104 deposits, and central channel. E) Interpretation of (D)

1105 Figure 9 10: Lower slope seismic lines and interpretations.

1106 Description of seismic facies in text and in Table 2. Exact

1107 locations of lines shown in Figures 2 and 3. A) Bassas da India

1108 line 017 (PTO-mig017_v1500). B) Interpretation of seismic

1109 line above in (A). B $\underline{\text { C) }}$ Juan de Nova line 234 (PTO-

1110 mig234_v1500_g0). D) Interpretation of seismic line above in

1111 (C). Colors delineate individual stratigraphic units, similar

1112 colors denote related units.

1113 Figure 11: Lower slope seismic lines and interpretations,

1114 continued. E스) Glorieuses Line 315 (mig315_v1500_g0). B)

1115 Interpretation of seismic line above in (A).

1116 Figure 12: Đ) Glorieuses Line 319 (mig319_v1500_g0) and

1117 notes on interpretation.

1118 Figure $10:$ A), B), C), Interpretations of the corresponding

1119 seismic lines in Figure 9A-9C. Colors delineate individual

1120 stratigraphic units, similar colors denote related units. 
1121 Figure 11ㄹ: A-C) Simplified diagram of sedimentation

1122 processes observed in core, seafloor bathymetry, and seismic

1123 data. A) Turbidite deposition resulting in interbedded carbonate

1124 sands-grainstone-packstones and seafloor muds B) Upper-

1125 middle slope failure, remobilizing previously deposited

1126 sediments (potentially including parts of the lithified platform)

1127 and redistributing them to the lower parts of the slope in the

1128 form of MTDs. C) Further deposition of carbonate sands

1129 grainstones-packstones in turbidites. Channelized deposits may

1130 erode into past MTDs and rework previously deposited

1131 material. D) Facies model that summarizes depositional

1132 elements and sedimentation processes in the Iles Eparses.

1133 Figure represents a synthesis of data from bathymetric,

1134 reflectivity, and seismic surveys of multiple platforms.

1135 Schematic only; not to scale.

1136

1137

1138

1139 
1141 Alfaro, E., Holz, M., 2014. Seismic geomorphological analysis

1142 of deepwater gravity-driven deposits on a slope system of the

1143 southern Colombian Caribbean margin. Marine and Petroleum

1144 Geology 57, 294-311.

1145 Alsop, G.I., Marco, S., Levi, T., Weinberger, R., 2017. Fold

1146 and thrust systems in Mass Transport Deposits. Journal of

1147 Structural Geology, 94, 98-115.

1148 Amblas, D., Ceramicola, S., Gerber, T.P., Canals, M., Chiocci,

1149 F.L., Dowdeswell, J.A., Harris, P.T., Huvenne, V.A., Lai, S.Y.,

1150 Lastras, G. and Iacono, C.L., Micalle, A., Mountjoy, J.J., Paull,

1151 C.K., Puig, P., and Sanchez-Vidal, A. 2018. Submarine

1152 canyons and gullies. In: Micallef, A., Krastel S., and Savini A.

1153 (eds) Submarine Geomorphology. 251-272, Springer Geology.

1154 Springer, Cham.

1155 Babonneau, N., Delacourt, C., Cancouët, R., Sisavath, E.,

1156 Bachèlery, P., Mazuel, A., Jorry, S.J., Deschamps, A.,

1157 Ammann, J. and Villeneuve, N., 2013. Direct sediment transfer

1158 from land to deep-sea: Insights into shallow multibeam

1159 bathymetry at La Réunion Island. Marine Geology, 346, 47-57.

1160 Bassias, Y., Roberts, G., Christoffersen, T., 2016. The nature of

1161 the crust offshore East Coast Africa When geology and seismic 
1162 meet potential fields in the search for hydrocarbons. East

1163 Africa: From Research to Reserves, Extended Abstract, The

1164 Geological Society of London 13-15 April 2016, 1-12.

1165 Battistini, R., Cremers, G., 1972. Geomorphology and

1166 vegetation of Iles Glorieuses. Smithsonian Institution. Atoll

1167 Research Bulletin 159, 27 p.

1168 Battistini, R., Gayet, J., Jouannic, C., Labracherie, M.,

1169 Peypouquet, J.P., Pujol, C., Pujos-Lamy, A., Turon, J.L., 1976.

1170 Etude des sédiments et la microfaune des îles Glorieuses (Canal

1171 de Mozambique). Cahiers ORSTOM, Série Géologie 8, 147-

1172171.

1173 Benn, D., Evans, D.J., 2014. Glaciers and glaciation.

1174 Routledge, 816 p.

1175 Berthois L., Battistini, R., 1969, Etude Sedimentologique de

1176 L'Ile Europa, Madagascar Revue de Geographie 15, 1-52.

1177 Betzler, C., Lindhorst, S., Eberli, G. P., Lüdmann, T., Möbius,

1178 J., Ludwig, J., Schutter, I., Wunsch, M., Reijmer, J., Hübscher,

1179 C., 2014. Periplatform drift: the combined result of contour

1180 current and off-bank transport along carbonate platforms.

1181 Geology 42, 871-874. 
1182 Betzler, C., Hübscher, C., Lindhorst, S., Lüdmann, T., Reijmer,

1183 J.J. and Braga, J.C., 2016. Lowstand wedges in carbonate

1184 platform slopes (Quaternary, Maldives, Indian Ocean). The

1185 Depositional Record, 2, pp.196-207.

1186 Blomeier, D.P.G., Reijmer, J. J., 2002. Facies architecture of an

1187 Early Jurassic carbonate platform slope (Jbel Bou Dahar, High

1188 Atlas, Morocco). Journal of Sedimentary Research 72, 462-

1189475.

1190 Breitzke, M., Wiles, E., Krocker, R., Watkeys, M.K., Jokat, W.,

1191 2017. Seafloor morphology in the Mozambique Channel:

1192 evidence for long-term persistent bottom-current flow and

1193 deep-reaching eddy activity. Marine Geophysical Research 38, 1194 241-269.

1195 Carter, L., 2001. A large submarine debris flow in the path of

1196 the Pacific deep western boundary current off New Zealand.

1197 Geo-Marine Letters, 21, 42-50

1198 Clark, J.D., Kenyon, N.H., Pickering, K.T., 1992. Quantitative

1199 analysis of the geometry of submarine channels: implications

1200 for the classification of submarine fans. Geology, 20, 633-636.

1201 Clarke, J.E.H., Mayer, L.A. and Wells, D.E., 1996. Shallow-

1202 water imaging multibeam sonars: a new tool for investigating 
shelf. Marine Geophysical Researches, 18, 607-629.

1205 Courgeon, S., Jorry, S.J., Camoin, G.F., BouDagher-Fadel,

1206 M.K., Jouet, G., Révillon, S., Bachèlery, P., Pelleter, E.,

1207 Borgomano, J., Poli, E., Droxler, A.W., 2016. Growth and

1208 demise of Cenozoic isolated carbonate platforms: New insights

1209 from the Mozambique Channel seamounts (SW Indian Ocean).

1210 Marine Geology 380, 90-105.

1211 Courgeon, S., Jorry, S.J., Jouet, G., Camoin, G., BouDagher-

1212 Fadel, M.K., Bachèlery, P., Caline, B., Boichard, R., Révillon,

1213 S., Thomas, Y. Thereau, E., 2017. Impact of tectonic and

1214 volcanism on the Neogene evolution of isolated carbonate

1215 platforms (SW Indian Ocean). Sedimentary Geology 355, 1141216131.

1217 Covault, J.A., Kostic, S., Paull, C.K., Sylvester, Z., Fildani, A., 1218 2017. Cyclic steps and related supercritical bedforms: building 1219 blocks of deep-water depositional systems, western North 1220 America. Marine Geology, 393, 4-20.

1221 Dartnell, P., Gardner, J.V., 2004. Predicting seafloor facies

1222 from multibeam bathymetry and backscatter data.

1223 Photogrammetric Engineering \& Remote Sensing 70, 108112241091. 


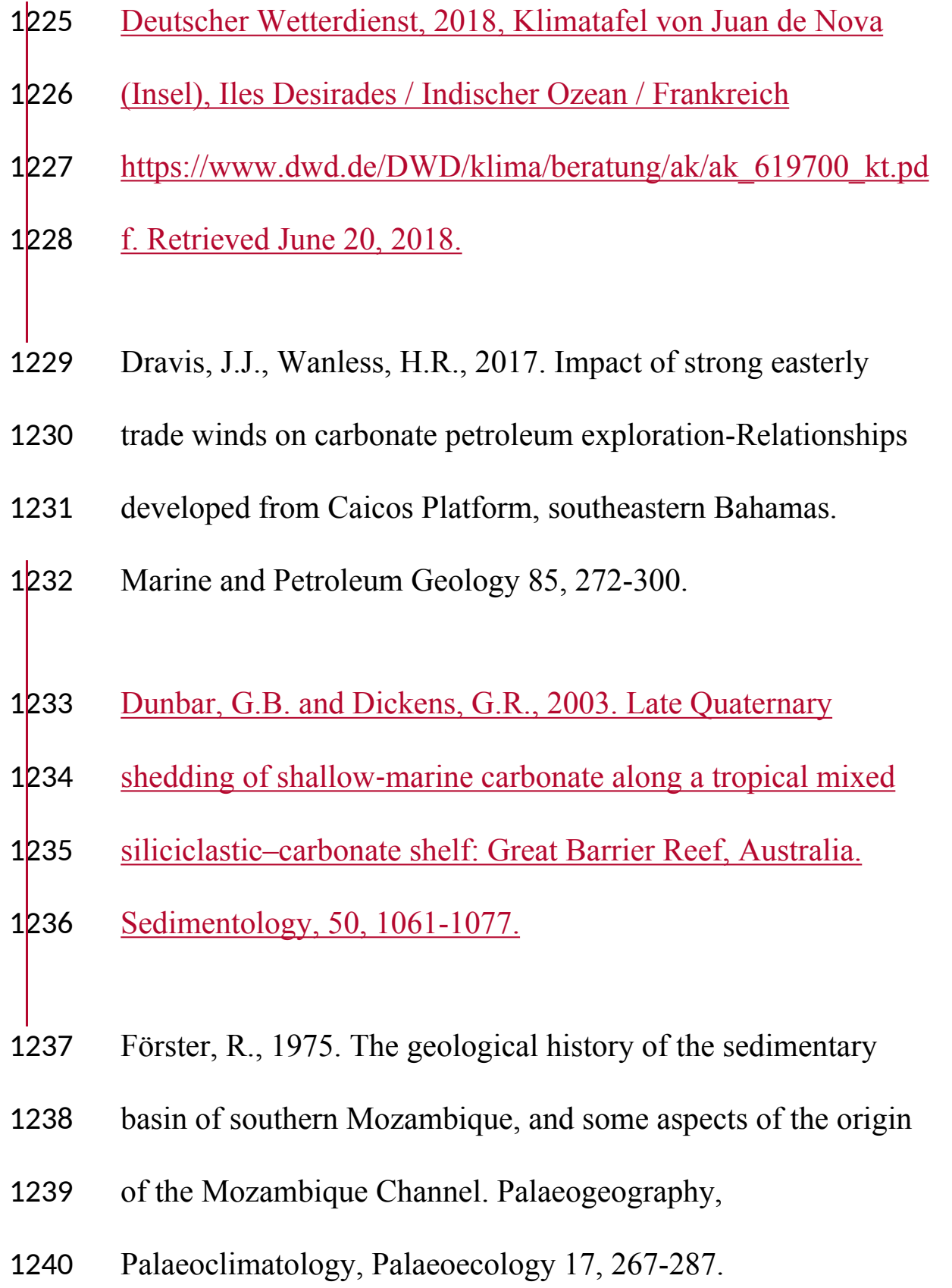

1241 Frey Martinez, J., Cartwright, J., Hall, B., 2005. 3D seismic

1242 interpretation of slump complexes: examples from the

1243 continental margin of Israel. Basin Research, 17, 83-108.

1244 Gervais, A., Savoye, B., Mulder, T., Gonthier, E., 2006. Sandy

1245 modern turbidite lobes: a new insight from high resolution

1246 seismic data. Marine and Petroleum Geology, 23, 485-502. 
1247 Gischler, E., 2011. Sedimentary facies of Bora Bora, Darwin's

1248 type barrier reef (Society Islands, South Pacific): the

1249 unexpected occurrence of non-skeletal grains. Journal of

1250 Sedimentary Research, 81,.1-17.

1251 Goldstein, R.H., Franseen, E.K., Dvoretsky, R.A., Sweeney,

1252 R.J., 2012. Controls on focused-flow and dispersed-flow

1253 deepwater carbonates: Miocene Agua Amarga Basin, Spain.

1254 Journal of Sedimentary Research 82, 499-520.

1255 Grammer, G.M., Ginsburg, R.N., 1992. Highstand versus

1256 lowstand deposition on carbonate platform margins: insight

1257 from Quaternary foreslopes in the Bahamas. Marine Geology $1258103,125-136$.

1259 Guillaume, M.M., Reyss, J.L., Pirazzoli, P.A., Bruggemann,

1260 J.H., 2013. Tectonic stability since the last interglacial offsets

1261 the Glorieuses Islands from the nearby Comoros archipelago.

1262 Coral Reefs 32, 719-726.

1263 Hampton, M., and Lee, H., 1996. Submarine Landslides,

1264 Reviews of Geophysics 34, 33-59.

1265 Harris, D.L., Webster, J.M., De Carli, E.V., Vila-Concejo, A.,

1266 2011. Geomorphology and morphodynamics of a sand apron,

1267 One Tree reef, southern Great Barrier Reef. Journal of Coastal

1268 Research, 64, 760. 
1269 Hay W.W., 2014. Submarine Canyons. In: Harff J., Meschede

1270 M., Petersen S., Thiede J. (eds) Encyclopedia of Marine

1271 Geosciences. Springer, Dordrecht.

1272 Hine, A.C., Locker, S.D., Tedesco, L.P., Mullins, H.T.,

1273 Hallock, P., Belknap, D.F., Gonzales, J.L., Neumann, A.C.,

1274 Snyder, S.W., 1992. Megabreccia shedding from modern, low-

1275 relief carbonate platforms, Nicaraguan Rise. GSA Bulletin,

$1276104,928-943$.

1277 Hühnerbach, V. and Masson, D.G., 2004. Landslides in the

1278 North Atlantic and its adjacent seas: an analysis of their

1279 morphology, setting and behaviour. Marine Geology, 213, 343-

1280362.

1281 James, N. P., Jones, B., 2016. Origin of Carbonate Sedimentary

1282 Rocks. John Wiley \& Sons. 320 p.

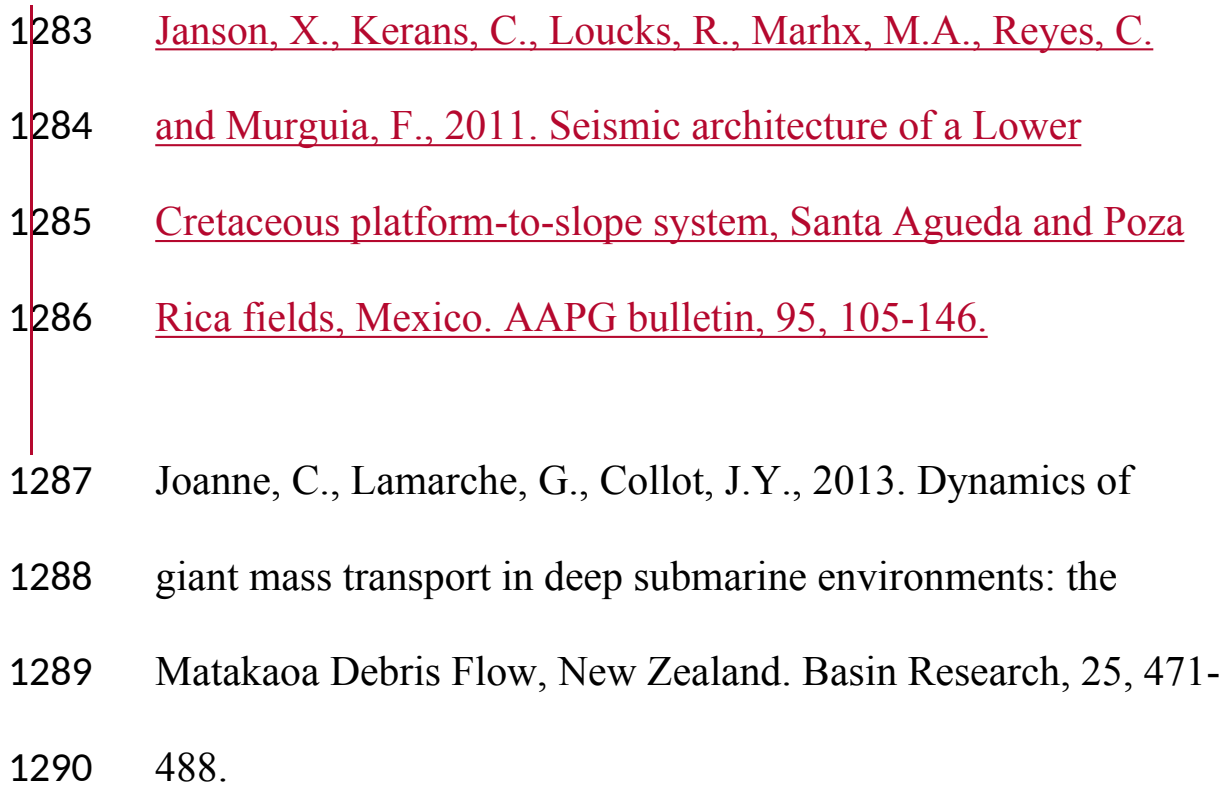


1291 Johnston, S.T., Thorkelson, D.J., 2000. Continental flood

1292 basalts: episodic magmatism above long-lived hotspots. Earth

1293 and Planetary Science Letters, 175, 247-256.

1294 Jorry, S., 2014. PTOLEMEE cruise, RV L'Atalante.

1295 http://dx.doi.org/10.17600/14000900

1296 Jorry, S.J., Camoin, G.F., Jouet, G., Le Roy, P., Vella, C.,

1297 Courgeon, S., Prat S., Fontanier C., Paumard V., Boulle J.,

1298 Caline B., Borgomano, J., 2016. Modern sediments and

1299 Pleistocene reefs from isolated carbonate platforms (Iles

1300 Eparses, SW Indian Ocean): A preliminary study. Acta

1301 Oecologica, 72, 129-143.

1302 Jouet, G., Deville, E., 2015. PAMELA-MOZ04 cruise, RV

1303 Pourquoi Pas ?. http://dx.doi.org/10.17600/15000700

1304 Kolla, V., Henderson, L. and Biscaye, P.E., 1976. Clay

1305 mineralogy and sedimentation in the western Indian Ocean.

1306 Deep Sea Research and Oceanographic Abstracts 23, 949-961.

1307 Lort, J.M., Limond, W.Q., Segoufin, J., Patriat, P., Delteil, J.R., 1308 Damotte, B., 1979. New seismic data in the Mozambique

1309 Channel. Marine Geophysical Research, 4, 71-89.

1310 Lowe, D.R., 1982. Sediment gravity flows: II Depositional

1311 models with special reference to the deposits of high-density 
1312 turbidity currents. Journal of Sedimentary Research, 52, 279-

$1313 \quad 297$.

1314 McGonigle, C. and Collier, J.S., 2014. Interlinking backscatter,

1315 grain size and benthic community structure. Estuarine, Coastal

1316 and Shelf Science, 147, 123-136.

1317 McIlreath, I.A., James, N.P., 1978. Facies models 13.

1318 Carbonate slopes. Geoscience Canada, 5, 189-199.

1319 Météo France, 2017.

1320 https://publitheque.meteo.fr/Donnees/DESC170531171564028

1321 9.KEYu07f7D3UO9xudD2U2fU9.html 1/2

1322 Milliman, J.D., Freile, D., Steinen, R.P. and Wilber, R.J., 1993.

1323 Great Bahama Bank aragonitic muds: mostly inorganically

1324 precipitated, mostly exported. Journal of Sedimentary

1325 Research, 63, 589-595.

1326 Moscardelli, L., Wood, L., Mann, P., 2006. Mass-transport

1327 complexes and associated processes in the offshore area of

1328 Trinidad and Venezuela. AAPG Bulletin, 90, 1059-1088.

1329 Mulder, T., Alexander, J., 2001. The physical character of

1330 subaqueous sedimentary density flows and their deposits.

1331 Sedimentology, 48, 269-299. 
1332

1333

1334 Mulder, T., Joumes, M., Hanquiez, V., Gillet, H., Reijmer,

133

1336

1337

1338

1339

1340

1341 alternatives to the submarine fan model for paleoenvironmental

1342 analysis and hydrocarbon exploration. Sedimentary Geology,

$134348,37-79$.

1344 Mullins, H.T., Heath, K.C., Buren, H., Newton, C.R., 1984.

1345 Anatomy of a modern open-ocean carbonate slope: northern

1346 Little Bahama Bank. Sedimentology, 31, 141-168.

1347 Olu, K., 2014. Rapport de fin de mission campagne Pamela-

1348 MOZ01. http://dx.doi.org/10.17600/14001000

1349 Payros, A., Pujalte, V., 2008. Calciclastic submarine fans: An

1350 integrated overview. Earth-Science Reviews, 86, 203-246.

1351 Pickering, K., Stow, D., Watson, M. and Hiscott, R., 1986.

1352 Deep-water facies, processes and models: a review and 
1353 classification scheme for modern and ancient sediments. Earth-

1354 Science Reviews, 23, 75-174.

1355 Posamentier, H.W. and Kolla, V., 2003. Seismic

1356 geomorphology and stratigraphy of depositional elements in

1357 deep-water settings. Journal of Sedimentary Research, 73, 367-

1358388.

1359 Posamentier, H.W., Martinsen, O.J. and Shipp, R.C., 2011. The

1360 character and genesis of submarine mass-transport deposits:

1361 insights from outcrop and 3D seismic data. In: Shipp, R.C.,

1362 Weimer, P., and Posamentier, H.W. (eds.), Mass-transport

1363 deposits in deepwater settings: Society for Sedimentary

1364 Geology (SEPM) Special Publication 96, 7-38.

1365 Prat, S., Jorry, S.J., Jouet, G., Camoin, G., Vella, C., Le Roy,

1366 P., Caline, B., Boichard, R., Pastol, Y., 2016. Geomorphology

1367 and sedimentology of a modern isolated carbonate platform:

1368 The Glorieuses archipelago, SW Indian Ocean. Marine

1369 Geology, 380, 272-283.

1370 Principaud, M., Mulder, T., Gillet, H. and Borgomano, J., 2015.

1371 Large-scale carbonate submarine mass-wasting along the

1372 northwestern slope of the Great Bahama Bank (Bahamas):

1373 Morphology, architecture, and mechanisms. Sedimentary

1374 Geology, 317, 27-42. 
1375 Quartau, R., Ramalho, R.S., Madeira, J., Santos, R., Rodrigues,

1376 A., Roque, C., Carrara, G. and da Silveira, A.B., 2018.

1377 Gravitational, erosional and depositional processes on volcanic

1378 ocean islands: Insights from the submarine morphology of

1379 Madeira Archipelago. Earth and Planetary Science Letters, 482,

$1380 \quad \underline{288-299 .}$

1381 Raharimahefa, T. and Kusky, T.M., 2010. Environmental

1382 monitoring of Bombetoka Bay and the Betsiboka Estuary,

1383 Madagascar, using multi-temporal satellite data. Journal of

1384 Earth Science, 21, 210-226.

1385 Reijmer, J.J., Swart, P.K., Bauch, T., Otto, R., Reuning, L.,

1386 Roth, S. and Zechel, S., 2009. A Re-Evaluation of Facies on

1387 Great Bahama Bank I: New Facies Maps of Western Great

1388 Bahama Bank (pp. 29-46). International Association of

1389 Sedimentologists Special Publication 41, 29-46.

1390 Saint-Ange, F., Bachèlery, P., Babonneau, N., Michon, L. and

1391 Jorry, S.J., 2013. Volcaniclastic sedimentation on the

1392 submarine slopes of a basaltic hotspot volcano: Piton de la

1393 Fournaise volcano (La Réunion Island, Indian Ocean). Marine

1394 Geology, 337, 35-52. 
1395 Schott, F.A., Xie, S.P., McCreary, J.P., 2009. Indian Ocean

1396 circulation and climate variability. Reviews of Geophysics, 47,

$1397 \quad 1-46$.

1398 Shanmugam, G., 2000. 50 years of the turbidite paradigm

1399 (1950s-1990s): deep-water processes and facies models - a

1400 critical perspective. Marine and Petroleum Geology, 17, 285-

1401342.

1402 Simpson, E.S.W., Schlich, R., Gieskes, J.M., Arch Girdley, W.,

1403 Leclaire, L., Marshall, B.V., Moore, C., Müller, C., Sigal, J.,

1404 Vallier, T.L., White, S.M., Zobel, B., 1974. Initial Reports of

1405 the Deep Sea Drilling Project, Sites 240-242, Volume 25,

1406 Washington (U.S. Government Printing Office) p. 65-176.

1407 Sisavath, E., Babonneau, N., Saint-Ange, F., Bachèlery, P.,

1408 Jorry, S.J., Deplus, C., De Voogd, B. and Savoye, B., 2011.

1409 Morphology and sedimentary architecture of a modern

1410 volcaniclastic turbidite system: The Cilaos fan, offshore La

1411 Réunion Island. Marine Geology, 288, 1-17.

1412 Talling, P.J., Masson, D.G., Sumner, E.J., Malgesini, G., 2012.

1413 Subaqueous sediment density flows: depositional processes and

1414 deposit types. Sedimentology, 59, 1937-2003.

1415 Tcherepanov, E.N., Droxler, A.W., Lapointe, P. and Mohn, K.,

1416 2008. Carbonate seismic stratigraphy of the Gulf of Papua 
1417 mixed depositional system: Neogene stratigraphic signature and

1418 eustatic control. Basin Research, 20, 185-209.

1419 Testut, L., Duvat, V., Ballu, V., Fernandes, R.M., Pouget, F.,

1420 Salmon, C., Dyment, J., 2016. Shoreline changes in a rising sea

1421 level context: The example of Grande Glorieuse, Scattered

1422 Islands, Western Indian Ocean. Acta Oecologica, 72, 110-119.

1423 Van Sebille, E., Scussolini, P., Durgadoo, J.V., Peeters, F.J.,

1424 Biastoch, A., Weijer, W., Turney, C., Paris, C.B. and Zahn, R.,

1425 2015. Ocean currents generate large footprints in marine

1426 palaeoclimate proxies. Nature Communications, 6, 6521.

1427 Wiles, E., Green, A.N., Watkeys, M.K. and Jokat, W., 2017.

1428 Zambezi continental margin: compartmentalized sediment

1429 transfer routes to the abyssal Mozambique Channel. Marine

1430 Geophysical Research, 38, 227-240.

1431 Wilson, P.A. and Roberts, H.H., 1995. Density cascading: off-

1432 shelf sediment transport, evidence and implications, Bahama

1433 Banks. Journal of Sedimentary Research, 65, 45-56.

1434 Yamano, H., Cabioch, G., Pelletier, B., Chevillon, C.,

1435 Tachikawa, H., Lefêvre, J. and Marchesiello, P., 2015. Modern

1436 carbonate sedimentary facies on the outer shelf and slope

1437 around New Caledonia. Island Arc, 24, 4-15. 
Highlights:

- First study to describe the slopes of volcano-cored carbonate platforms in detail

- Slope sediments composed of muds and platform-derived carbonate sands

- Slopes contain channels, fans, and mass transport deposits

- Sedimentation is primarily controlled by inherited topography and dominant winds

- Excellent example of complete source-to-sink sedimentary system 
Sedimentation adjacent to atolls and volcano-cored carbonate platforms in the Mozambique Channel (SW Indian Ocean)

Gwenael JOUET (Gwenael.Jouet@ifremer.fr) ${ }^{\mathrm{a}}$

11

*Corresponding author

13 29280 Plouzané, France

18 Occidentale (IUEM-UBO), 29280 Plouzané, France.

${ }^{a}$ Laboratoire Géodynamique et Enregistrement Sédimentaire (GM-LGS) - Institut Français de Recherche pour l'Exploitation de la Mer (IFREMER) - Pointe du Diable,

${ }^{b}$ CNRS, UMR6538, Laboratoire Géosciences Océan, Institute Universitaire Européen de la Mer - Université de Bretagne 22 


\section{Abstract}

25 Recently acquired data from the Iles Eparses (southwestern

26 Indian Ocean) reveal new information about the

27 geomorphology, depositional processes, and sedimentary

28 deposits on the slopes of atolls and atoll-like platforms. The

29 deposits discussed here lie on the deepwater flanks of isolated,

30 inactive volcanos that are capped by shallow, relatively flat

31 carbonate platforms $45-210 \mathrm{~km}^{2}$ in area. Much of the slope

32 geomorphology is controlled by the underlying volcanic edifice.

33 Steep $\left(\sim 25-35^{\circ}\right)$ upper slopes consist of outcrops of volcanic

34 basement, smooth banks, failure scarps, and channels.

35 Sedimentary features seen in the lower slope and proximal

36 basin (2000-3500 m deep) consist of channels, levees, lobes,

37 and mass transport deposits (MTDs). In places, channels

38 terminate 13-18 $\mathrm{km}$ from the platform margin, ending in lobes

39 up to $3.5 \mathrm{~km}$ across, a feature not often seen in modern

40 carbonates. In the subsurface, MTDs are present near all

41 platforms. Within MTDs, seismic character is variable, often

42 consists of chaotic reflections indicative of sediment gravity

43 flow processes. Subsurface units with organized (retro- or

44 progradational) reflections are interpreted as turbidite lobes or

45 MTDs with compressional features. Core taken within lobes

46 and near the base of slopes reveal decimeter-scale turbidites

47 and debrites composed primarily of graded and massive

48 bioclastic grainstones and packstones with abundant neritic 
skeletal components, interbedded with hemipelagic aragonitic

and clay-rich foraminiferal ooze. Slope depositional processes

are therefore primarily gravity-driven and occur at different

52 scales; i.e., bed-scale turbidites and muds may be remobilized

and redeposited through slope failure and deposition of large

54 MTDs. Dominant wind direction may also play a role in slope

sedimentation: leeward slopes are generally less rugose and

show increased sedimentation at the toe of the slope. This study

57 thus provides new insight into depositional systems

surrounding atoll-like carbonate platforms, and provides a new

analogue for similar deposits in the geologic record.

60 Keywords: atoll; carbonate; Indian Ocean; slope; deepwater

61 sediments

\section{Introduction}

Sediments on carbonate slopes are well-represented in the

64 ancient geologic record (Blomeier and Reijmer, 2002, and

references therein), and are an important component of

66 carbonate depositional systems. However, a detailed,

67 actualistic understanding of these environments in modern

68 settings was hampered for many years by the inaccessibility of

69 deepwater deposits in modern oceans (McIlreath and James,

70 1978), and much work remains to be done. Although many

71 studies have documented the shallow-water portions of modern

72 carbonate platforms and coral atolls (e.g., Reijmer et al., 2009;

73 Gischler, 2011; Harris et al., 2011), most existing research on 
modern deepwater allochthonous carbonates (distinguished

75 here as those predominantly transported into the deep sea from

76 elsewhere, as opposed to cold-water carbonate muds and

77 buildups precipitated in situ) has focused on a limited number

78 of well-known settings (e.g., the Caribbean). Although more

79 recent studies have expanded research into new areas (e.g., the

80 Maldives, Papua New Guinea, NE Australia, and New

81 Caledonia; Betzler et al., 2016; Tcherepanov et al., 2008;

82 Dunbar and Dickens, 2000; Yamano et al., 2015, respectively),

83 relatively few studies have been conducted in the southern

84 Indian Ocean. More studies in new areas and in different geo-

85 environmental settings are required in order to understand the

86 full range of carbonate slope sedimentation around the world.

87 This study examines the submarine slopes of four

88 isolated, volcano-cored atolls and atoll-like carbonate platforms

89 in the southern Indian Ocean (Fig. 1) with the goal of

90 improving our understanding of the depositional processes and

91 products operating on their slopes and nearby basin floors. The

92 deposits formed when carbonate sediments are transferred,

93 deposited, and remobilized on the platform slopes are the focus

94 of this paper, as well as the mechanisms responsible for such

95 deposits. By using seismic, bathymetric, and core data, this

96 study reveals new information about the geomorphology and

97 sedimentology of these unique depositional settings. Because of

98 their relatively small size (on a scale of tens of kilometers), the 
entire sedimentary system of each platform can be examined as

100 a whole, forming a complete source-to-sink picture of

101 sedimentation. This information is used to create a new, unique

102 facies model for the type of atoll-like carbonate platforms

103 discussed here, which are lacking in the geological literature,

104 and provides a point of comparison to other, genetically

105 different carbonate systems elsewhere.

\section{2. Regional Setting}

The islands that are the focus of this study (Grande

108 Glorieuse, Europa, Juan de Nova, and Bassas da India) lie

109 within and around the modern Mozambique Channel (MC), an

110 elongate basin in the Indian Ocean between the African

111 continent and the island of Madagascar (Fig. 1). Together, these

112 islands and the waters surrounding them are known as the Iles

113 Eparses, and are part of the French Southern and Antarctic

114 Lands. Islands are the subaerial portions of carbonate platforms

115 that sit atop volcanic pinnacles originating from the basin floor.

116 Platform tops are relatively flat and composed entirely of

117 carbonate; there is no central volcanic peak. All are

118 circular/equant in map view, except for Glorieuses, which has a

119 roughly triangular shape.

120 The detailed origins and tectonic histories of each of

121 these structures are not well-studied, but the emergence of all

122 platforms is a result of the interplay between tectonic uplift and

123 subsidence, extrusive volcanic growth, eustasy, and the rate of 
carbonate aggradation, all of which vary between platforms

125 (Courgeon et al., 2016). Platforms are of different ages and

126 genetic origins and may be related to localized hotspot chains

127 or mantle plumes. The Glorieuses Archipelago (Fig. 2A, 2B) is

128 at minimum Paleocene in age and is a part of a linear ridge of

129 volcanoes that also encompasses the nearby Comoros

130 (Courgeon et al., 2016). It shows no indication of any

131 significant drowning events during its lifespan, and has been

132 interpreted to now be tectonically stable (with a very slow

133 uplift of $\sim 0.012 \mathrm{~mm} /$ year since $\sim 130 \mathrm{ka}$ ) owing to its position

134 away from the Somalia-Nubian plate boundary (Guillaume et

135 al., 2013). Juan de Nova (Fig. 2C, 2D) has been studied very

136 little; however, it likely has a granite core (Förster, 1975) and is

137 not currently undergoing any notable uplift or subsidence

138 (Testut et al., 2016). Bassas da India (Fig. 3A, 3B) and Europa

139 (Fig. 3C. 3D) have been hypothesized to be related to the

140 Quathlamba hotspot, which formed the archipelago up to 60

141 Mya and is currently under Lesotho (Johnston and Thorkelson,

142 2000). Bassas da India specifically has also been shown to have

143 originated in the late Oligocene/early Miocene, and has been

144 volcanically active as late as the early Pleistocene (Courgeon et

145 al., 2017). Large-scale faulting, structural deformation, and

146 volcanism in Bassas da India and associated submarine banks

147 have been tied to a southern extension of the East African Rift

148 system (Courgeon et al., 2016). 
150 the Paleocene and Early Miocene, and continues until the

151 present day (Courgeon et al., 2016; 2017). Sediment production

152 was periodically interrupted by episodes of volcanism and

153 subaerial exposure, which occurred during relative sea-level

154 lowstands and resulted in karstification of the platform top.

155 Platform top sediments are generally poorly understood; the

156 sedimentology of Ile Europa was first examined from a

157 geological perspective in the 1960s (Berthois and Battistini,

158 1969) and on Glorieuses in the 1970s (Battistini and Cremers,

159 1972; Battistini et al., 1976). These preliminary studies noted

160 the carbonate sediment composition and basic facies

161 asymmetry of platform tops, as well as the existence of paleo-

162 reefs. Sediment atop the Glorieuses platform has been shown

163 by Prat et al. (2016) to be partitioned into five asymmetric

164 facies zones defined by hydrology, storm events, and the

165 distribution of carbonate producing organisms. Here, sediment

166 is remobilized by large sandwaves that ultimately likely

167 migrate off-platform, leading to a relatively continuous supply

168 of sand-sized sediment exported to the platform slope and

169 beyond. Similar asymmetric facies distributions and winnowing

170 processes can be inferred to be occurring on the tops of other

171 platforms as well (Jorry et al., 2016). Winds are predominantly

172 from the south on all islands except for Glorieuses, where they

173 are primarily from the east (Fig. 1E; Météo France, 2017). 
174 Currents come from the east at Glorieuses, but are variable

175 surrounding other islands due to the presence of anticyclonic

176 eddies moving southward through the channel (Schott et al.,

177 2009).

178 Most Iles Eparses platforms lack the defining features of

179 atolls; i.e., a fringing reef and central lagoon. Only Bassas da

180 India fits the definition; the other Iles Eparses are referred to

181 here as 'atoll-like carbonate platforms' to distinguish them

182 from both true atolls and from more traditionally defined

183 carbonate platforms, e.g. the Bahamas. The tops of Glorieuses

184 and Juan de Nova platforms (Fig. 2) contain small asymmetric

185 vegetated islands, but are mostly submerged, whereas the top of

186 Europa (Fig. 3C, 3D) is predominantly subaerial and contains a

187 single large tidal channel surrounded by mangrove forest.

188 Bassas da India does contain a continuous, circular, marginal

189 reef exposed only at low tide, with a fully enclosed inner

190 lagoon (Fig. 3A, 3B). Today, the exposed surface area of all the

191 islands in question (totaling approximately $42 \mathrm{~km}^{2}$ ) is

192 significantly smaller than the predominantly subaqueous

193 portions (around $500 \mathrm{~km}^{2}$, generally ranging between of 0-40 m

194 water depth). All platform tops are composed of carbonate

195 sediment, with no volcanic outcrops or sediments visible, and

196 subaerially exposed islands show evidence of recent

197 karstification (Jorry et al., 2016).

198 3. Methodology and Data Set 
Data used in this study were collected during three

200 research cruises in the MC: PTOLEMEE (R/V L'Atalante;

201 August/September 2014, Jorry, 2014), PAMELA-MOZ1 (R/V

202 L'Atalante; September/October 2014, Olu, 2014), and

203 PAMELA-MOZ4 (R/V Pourquoi Pas?; November/December

204 2015, Jouet and Deville, 2015). Dataset includes:

205

- High-resolution bathymetry and substrate backscatter/reflectivity measurements of the deep seafloor, using a Kongsberg EM122 multibeam echosounder

- Seismic acquisition with high-speed multichannel (high-resolution, airgun-sourced ) and CHIRP subbottom profiler (very high-resolution, swept-frequency source) methods

- Kullenberg and Calypso piston coring systems, used to

217 velocity of approximately 1700 meters/second, based on 218 assumptions discussed in Lort et al. (1979) and DSDP Reports

219 from the region (wells 240-242 show velocities from 1.5-1.9

$220 \mathrm{~km} / \mathrm{s}$ for the Oligocene; Simpson et al., 1974). This method

221 provides a first approximation for sediment thickness when 222 deep core control is not available. 
224 of the Juan de Nova slope was calculated by: 1) drawing the

225 map-view representation of the -600-meter contour line, 2)

226 measuring radii from a central point to the edge of the contour

227 line, 3) subtracting a roughly circular shape to correct for

228 overall shape of the platform, 4) assessing the standard

229 deviations of corrected radii lengths. With this method, higher

230 rugosity or roughness of the slope results in higher standard

231 deviations. Measurement of several thousand radii was

232 automated using a custom Python script. Standard deviations

233 were then compared for the leeward vs windward sides of the

234 platform to quantitatively measure slope rugosity.

235 Core sediments were initially described visually, and

236 selected intervals were selected for further analysis. Grain size

237 was measured with a Malvern Mastersizer 3000 laser

238 diffraction particle size analyzer, capable of measuring all

239 grains from $10 \mathrm{~nm}$ to $2 \mathrm{~mm}$. Carbonate sand composition was

240 determined by counting several hundred individual grains

241 under a reflected light binocular microscope: samples were

242 sieved and split into three size fractions above $63 \mu \mathrm{m}$, and

243 results were combined to provide a bulk composition.

244 Sediments, both muds $(<63 \mu \mathrm{m})$ and carbonate

245 grainstones/packstones (dominant particle size $>63 \mu \mathrm{m}$ ), were

246 imaged and analyzed with a FEI Quanta 200 scanning electron

247 microscope (SEM) equipped with an Oxford Instruments 
248 Energy Dispersive Spectroscopy (EDS) detector. X-Ray

249 diffraction (XRD) for mineralogy of muds was performed in-

250 house using a Bruker AXS diffractometer.

251 4. Results

2524.1 Geomorphologic elements

253 4.1.1 Platform tops and terraces

Overall, platforms and their volcanic edifices have a

255 conical morphology with a small, relatively flat top (Fig. 4).

256 The volume of carbonate sediment that has accumulated atop

257 each volcano is unknown; neither deep cores nor deep seismic

258 have been acquired on the tops or upper slopes of the platforms.

259 All investigations of platform tops (by dredging or coring),

260 however, have only yielded carbonates. On Glorieuses and

261 Bassas da India, the main platform tops are attached to deeper

262 submarine terraces 700-750 and 400-500 m below sea level,

263 respectively (Figs. 4A, 4B). The terrace on the northwestern

264 side of Glorieuses is small $\left(3.9 \mathrm{~km}^{2}\right.$; Fig. $\left.4 \mathrm{~A}\right)$, and lies between

265 the main platform and a submarine volcanic pinnacle without a

266 flat top (labeled ' $T$ ' in Fig. 2A). On Bassas da India, the

267 submerged terrace is separated from the main platform by a

268 large fault (Figs. 3A, 4B); previous studies (Courgeon et al.,

269 2017) interpret the terrace as a product of Pliocene-Pleistocene

270 fault movement. Volcanic rocks and small volcanic clasts

271 within sediment have been found on the submarine terrace of

272 Bassas da India. 
275 the shallow, flat top to a steep upper slope with a 25-35 degree

276 gradient (Fig. 4). These upper slope surfaces have the highest

277 overall gradient of anywhere between the platform top and the

278 adjacent abyssal plain, and are smoother than the mid-slope

279 below (Fig 4C). In general, the broad, smooth areas of upper

280 slopes are more contiguous on the leeward side of islands.

281 Seismic lines taken on the middle slope of Europa (Fig. 4D)

282 show that these areas likely contain only a thin veneer of

283 sedimentary cover. Smooth upper slopes may be interrupted,

284 however, by steep-sided (generally 30-50 degrees) outcrops of

285 basement (e.g., Fig. 4C). Basement outcrops are highly variable

286 in size, and in seismic are characterized by low- to variable-

287 amplitude reflections that differ from the overlying

288 sedimentation patterns (Fig. 4D). These outcrops are more

289 abundant slightly lower in the slope where the gradient

290 decreases to 12-20 degrees. Basement is likely composed of

291 volcanics, as previously interpreted by Lort et al., 1979, and

292 Bassias et al., 2016.

$293 \quad 4.1 .3$ Escarpments

294

295 surfaces may also be broken by escarpments and slope failure

296 scars. On the Glorieuses platform, a linear escarpment at a

297 water depth ranging between 700 and 850 meters is traceable 
298 for approximately $70 \mathrm{~km}$ around the platform's perimeter (Fig.

$2994 \mathrm{~A}$ and inset). This escarpment is most prominent on the

300 northwest side of the platform, and reaches around 120 meters

301 in height with a slope of 50-80 degrees. It lies at the same

302 bathymetric depth as the small terrace to the northwest of the

303 main platform. Similar long, well-developed linear escarpments

304 are not seen on other platform slopes.

305 4.1.4 Slope failure scars

306 Elsewhere, smaller, discrete scarps (c.f. Hampton and

307 Lee, 1996) are evident on several sites in the upper slope. On

308 Juan de Nova, multiple arcuate scarps 400-2000 m across incise

$30960-150 \mathrm{~m}$ into the upper slope surface (Fig. 5A-5B). At least 10

310 of these are present around the islands' perimeter, all of which

311 occur where the surrounding slope gradient ranges from $22^{\circ}-$

$31228^{\circ}$. Arcuate scarps, however, are not distributed evenly; they

313 are more abundant on the windward south side of the platform,

314 with the leeward side having a quantitatively smoother, lower

315 rugosity slope (Fig. 5C). The morphology of scarps are also

316 different - scarps on the leeward slope generally have less

317 relief, on the order of 50-60 meters as opposed to 100 meters or

318 more on windward sides. As a first approximation, the volume

319 of sediment once filling these scarps was calculated using a

320 series of three-dimensional wedges, based on the gradient

321 found above and below the scar in question (Table 1).

322 Individual scarp volumes range from approximately 1 to 10 
$323 \mathrm{~km}^{3}$, with the caveat that true volumes are slightly smaller due

324 to their irregular shape (Fig. 5A, 5B), a factor not included in

325 the calculation. These small individual scarps are not present on

326 the slopes of other platforms; however, on Bassas da India a

327 scallop-shaped indentation on the platform top (4 km across;

328 see Fig. 6A) may also be the product of past slope failure on a

329 much larger scale. The slope just below this indentation is

330 highly rugose and is the source of channels that extend to the

331 basin floor. Large areas of erosion are also seen on the southern

332 side of Europa (Fig. 6B), but do not have the distinctive arcuate

333 morphology seen on Juan de Nova.

334

335

346 a distinct base (Fig. 4D). In map view, channels are generally

347 straight, with flat bottoms and walls generally between 40 and 
$348100 \mathrm{~m}$ high (Fig. 4C), though this varies considerably. In lower

349 slopes, channels may erode into sediments rather than

350 basement. Further details of sedimentary deposits associated

351 with channels and their geomorphologic elements are discussed

352 below.

3534.2 Sediments of the slope and proximal basin

354 4.2.1 Distribution

355 Most sediment in the Iles Eparses slopes accumulates in

356 the lower slope, where the gradient is less than $10^{\circ}$. Seismic

357 and bathymetric data reveal that lower slopes contain a wedge-

358 shaped sedimentary package that extends to up to 30 kilometers

359 from the platform top (Figs. 2, 3 and 7; seismic data showing

360 sedimentary nature of lower slope sediments in Fig. 7A). These

361 sediments are elevated relative to the generally flat basin floor

362 (Figs. 2 and 3), and have a higher gradient (usually $3^{\circ}-6^{\circ}$, vs. 0 -

$3633^{\circ}$ ). The change in slope gradient marks the slope base;

364 sediments beyond this point are considered to be in the adjacent

365 basin. Where bathymetric data is available around the entire

366 slope perimeter, lower slopes can often be seen to have

367 asymmetric distribution around the platform, with bathymetric

368 highs occurring more prominently on leeward sides of at least

369 some platforms (especially in Europa, Glorieuses, and Juan de

370 Nova; see Figs. 2 and 3). Representative slope profiles on

371 windward and leeward sides of the platforms are shown in

372 Figure 7B-D. Although upper slopes may similar or steeper on 
373 either side, in each instance the lower slope extends further

374 from the platform top on the leeward side.

375 4.2.2 Lithologies

376 Cores acquired on lower platform slopes (locations in

377 Figs. 2 and 3) reveal the character of sediments in the shallow

378 subsurface. A selection of representative core is shown in

379 Figure 8A-D, all of which consist predominantly of

380 foraminiferal ooze interbedded with beds of unlithified

381 carbonate grainstones, packstones, or wackestones. These

382 coarser-grained carbonate beds make up a minor but significant

383 proportion of core thicknesses, usually between $<1$ and $20 \%$.

384 The dominant grain size in these beds is generally fining-

385 upward, with most constituent particles less than $0.5 \mathrm{~mm}$ (Fig.

$3868 \mathrm{E}$ ), although many beds have a basal lag with coarser skeletal

387 fragments. Carbonate sediments within these beds are

388 unlithified and well-sorted, without clear sedimentary

389 structures other than occasional horizontal laminae. The sand-

390 sized component of coarser units (shown in blue in Fig. 8A-8D)

391 is composed of $100 \%$ calcareous material, including many taxa

392 normally found in the photic zone: coral and algal fragments,

393 echinoid spines, and well-preserved gastropods (Figs. 8F, 8G).

394 The tests of planktonic and benthic foraminifers also make up a

395 significant portion of these sands (up to $35 \%$ of identifiable

396 grains; Fig. 8F). Interbedded with these sediments are thicker

397 beds of foraminiferal carbonate ooze. The clay-sized fraction of 
these background micritic muds is not identifiable petrographically, however, SEM images (Fig. $8 \mathrm{H}$ ) reveal the

400 presence of needle-like crystals, as well as platy grains. EDS

401 analysis (Fig. 8H) shows that intervals dominated by needle-

402 like crystals are enriched in calcium and oxygen, suggesting a

403 carbonate mineralogy, whereas those dominated by platy grains

404 have elevated amounts of silicon, aluminum, and oxygen - all

405 elements that are components of silicate minerals. To better

406 understand the composition of this component of the mud,

407 XRD analysis was performed on a sample from the same

408 approximate interval (MOZ4-CS09, 100-102 cm). Results show

409 the presence of quartz, feldspar, and various clay minerals,

410 confirming the siliciclastic nature of some of these grains (Fig.

$4118 \mathrm{H})$.

412 4.2.3 Channels, lobes, and levees

$413 \quad$ Upper slope gullies (sensu Amblas et al., 2018) evolve

414 distally into channels that are traceable through their increased

415 reflectivity (backscatter) values (shown in red in Figs. 2B, 2D,

$4163 \mathrm{~B}, 3 \mathrm{D}$, and 9A-9C). All lower slope channels are extremely

417 straight, with most sinuosities above 0.9, typical gradients

418 between $5^{\circ}$ and $10^{\circ}$, and with walls that range between $40-100$

419 m above the channel floor. Like the overall slope, the gradient

420 of channels floors decreases steadily basinward (see inset of

421 Figure $4 \mathrm{C}$, showing gradient decrease from $\sim 30^{\circ}$ to $\sim 10^{\circ}$ over

422 the course of $5 \mathrm{~km}$ ). In map view, most channels originate in 
423 the upper slope and continue downslope to reach the basin

424 floor. Areas of increased backscatter intensity often taper

425 basinward to a point (e.g., Fig. 9A), although channel forms

426 may be seen in bathymetric relief to continue further

427 downslope. In several places, however, an individual upper

428 slope incised channel splits into multiple channels in the mid-

429 slope (e.g., the eastern side of Europa, denoted by an arrow in

430 Fig. 2D, and the northeastern side of Bassas da India; Fig. 9B).

431 This point of channel bifurcation most often occurs where the

432 slope gradient decreases to around $10^{\circ}$. The lower slope

433 channels that radiate outward from this point are smaller and

434 also straight, and often reach the basin floor. On the

435 northwestern side of Glorieuses, some slope channels contain a

436 regularly-spaced series of escarpments, 450-750 m apart and

$437 \quad 15-60 \mathrm{~m}$ high that form an undulatory topography within the

438 channel (Fig. 9B).

439 On the northern side of Europa, at least one lower slope

440 channel is bounded by well-defined raised sedimentary deposits

441 with a 'bird-wing' shape in cross-section, seen in seismic data

442 in Figures 9D and 9E and interpreted as a levee deposit. These

443 deposits and the channel axis are visible in bathymetric data as

444 well, though the channel itself shows no increased backscatter

445 values. In seismic, levee deposits are transparent with faint, but

446 continuous, reflections (Facies E, described below), and reach a

447 maximum thickness of 280 meters in the seismic profile shown 
448 in Fig 9D. Height from the channel floor to the highest part of

449 the levee is 70 meters or less. The central channel floor is

450 characterized by higher amplitude reflections, as are the

451 deposits several kilometers beyond the levee boundaries. Levee

452 deposits eventually merge into transparent, furrowed sediments

453 on the basin floor, shown on the right side of Figure 9D and

454 visible in on the seafloor in Figure 3C (labeled). A 27-m core

455 (MOZ4-CS23; see portion in Fig. 8D) taken directly atop the

456 levee shown in Figure 9D and 9E consists almost entirely of

457 foraminiferal carbonate mud, with carbonate sand beds

458 occurring only near its base.

459 Channels may terminate in a lobe near the bottom of the

460 lower slope or on the basin floor, although lobes are not always

461 present. A distinct lobe (visible in backscatter imagery; Fig.

4629 9) on the northeastern side of Bassas da India was selected for

463 more detailed investigation and was sampled by core MOZ1-

464 KS27 (Fig. 8A). The lobe is approximately 4 kilometers across

465 at its widest visible point, is estimated to range from 0 to tens

466 of meters thick based on seismic data, and begins where the

467 slope gradient is around $3^{\circ}$. Core MOZ1-KS27 (Fig. 8A),

468 despite only being $4 \mathrm{~m}$ long, contains multiple lithofacies

469 indicative of the lobe's composition. Above background

470 foraminiferal muds, a $\sim 30-\mathrm{cm}$ thick bed with a sharp lower

471 surface contains a basal layer of large $(10-15 \mathrm{~mm})$ coral and

472 algal fragments within a matrix of very coarse, bioclastic 
473 calcareous grainstone. This coarse skeletal grainstone facies is

474 overlain by a one-meter thick unit of carbonate packstone-

475 wackestone (dominant grain size around $0.3 \mathrm{~mm}$ ) that contains

476 irregular clasts of mud $2-20 \mathrm{~cm}$ in diameter, which roughly

477 increase in size upward through the unit. This facies is in turn

478 overlain by a 20 -cm thick, well-sorted, fining-upward bed

479 containing fine-to medium-grained carbonate grainstones (Fig.

$4808 \mathrm{E}$ ) with a similar composition to those seen elsewhere.

481 4.2.4 Subsurface seismic facies

$482 \quad$ Seismic lines acquired on the lower slopes and proximal

483 basins of Iles Eparses platforms show several distinct types of

484 sedimentary deposits, which can be classified based on the

485 amplitude, continuity, and orientation of their internal

486 reflections (Table 2). Seismic facies are found in different

487 locations surrounding each platform, and not all facies are

488 present surrounding each locality.

489 Sediments comprising the basin floor are typically

490 characterized by horizontal to sub-horizontal, continuous, high-

491 amplitude reflections that extend to the outer limits of seismic

492 data (Facies A; Figs. 10 and 11) and that onlap onto the lower

493 slopes of platforms. These are seen in all seismic lines that

494 intersect the basin floor. On the eastern side of Juan de Nova,

495 sediments of this facies originate from the Madagascar shelf

496 and form thick, laterally continuous sediment packages

497 separated by clearly identifiable onlap surfaces (Figs. 10C, 
10D). Here, this facies interfingers with Facies B (transparent,

499 chaotic reflections; Fig. 10C), which is contained within

500 discrete units that taper away from the Juan de Nova platform.

501 These subsurface units originate from the JDN platform (Fig.

502 10D), are 30-40 m thick, and extend seven or more kilometers

503 into the basin. Internal character in these units is consistently

504 transparent and shows little proximal-distal evolution. On the

505 northwestern side of the Glorieuses platform, chaotic,

506 transparent Facies B is present in dip line 315 around $120 \mathrm{~m}$

507 below the seafloor surface (Fig. 11A, 11B). Here, the unit

508 containing this facies extends only $\sim 2 \mathrm{~km}$ away from its origin

509 point, forming a thicker, shorter seismic unit that is laterally

510 adjacent to Facies D (discussed below).

511 In Bassas da India, a large, amalgamated unit of Facies C

512 (chaotic facies of mixed amplitude) makes up a significant

513 portion of the subsurface on the northeastern side of the island

514 (Figs. 10A, 10B). The deposit sits directly atop basement, and

515 decreases in thickness over the course of approximately $15 \mathrm{~km}$.

516 This unit shows little interfingering with adjacent hemipelagic

517 basinal sediments; up to 320 meters of flat basin sediments

518 unconformably onlap the unit. Internally, this unit contains at

519 least one strongly reflective basement-parallel surface, and

520 contains both high- and low-amplitude chaotic reflections.

521 Units containing both the chaotic reflections of Facies C

522 and the more organized reflections of Facies D are present 
523 within discrete units on the northwestern side of Glorieuses in

524 dip lines 315 and 319 (Figs. 11A, 11B,12). The most prominent

525 unit containing these facies, up to $\sim 80 \mathrm{~m}$ thick, forms a wedge-

526 shaped sediment package extending approximately $12 \mathrm{~km}$

527 basinward from its origin point on the lower slope. In this unit,

528 seismic Facies D contains both platform-and basinward-dipping

529 high-amplitude reflections. Reflections in this unit become

530 thinner and increasingly horizontal, ultimately terminating into

531 the continuous, high amplitude, 'railroad tracks' that make up

532 Facies A in the deep basin away from platforms. Just to the

533 northwest of this line, a different unit containing organized,

534 inclined reflections (Facies D; Line 319, Fig 12) comprises a

535 significant portion of the subsurface, forming an irregular unit

536 that tapers basinward and is not well-separated from the

537 underlying sediments. In this unit, the seafloor surface contains

538 a series of irregular, arcuate or linear ridges that are $10 \mathrm{~s}$ to $100 \mathrm{~s}$

539 of meters in relief with 25-50 m amplitudes (decreasing

540 basinward), and wavelengths of 700-1200 m (Fig. 12). Seismic

541 Line 319 crosses these ridges, and shows that they are the

542 surface expression of concave-downward seismic structures

543 that originate deeper in the subsurface. These structures are

544 characterized by a series of high-amplitude reflections that dip

545 back toward the platform and gradually become tangential to a

546 subhorizontal surface approximately $120 \mathrm{~m}$ deep (labeled on

547 Fig. 12). 
549 in the birdwing-shaped levee and channel deposits that make up

550 the lower slope. Reflections in this facies are mostly continuous

551 and low amplitude, though amplitude and continuity are

552 somewhat variable across the observed deposit. In strike line

553015 (Fig. 9D), reflections within the levee are parallel to each

554 other and to the seafloor surface. In dip profile (Fig. 7A) this

555 facies can be seen to grade into horizontal, parallel reflections

556 on the basin floor, which increase in amplitude basinward to

557 conformably become Facies A (Table 2).

\section{5. Discussion}

5595.1 Interpretation of sedimentary deposits

$560 \quad$ 5.1.1 Facies diversity

561 Cores reveal that deposits on the slopes and in the

562 proximal basins surrounding platforms are a combination of

563 pelagic and platform-derived sedimentation. Within muddy

564 deposits, clay minerals (Fig. 8H) are likely the product of

565 weathering, suspension and transport of clastic sediments in

566 seawater, and subsequent deposition through pelagic rain

567 (Facies G of Pickering et al., 1986). These lithologies are

568 present in all cores and may originate from the African

569 continent (Kolla et al., 1976; Wiles et al., 2017), Madagascar

570 (the nearby Betsiboka River exports large volumes of fine-

571 grained sediment; Raharimahefa and Kusky, 2010), or

572 elsewhere. While the carbonate platforms discussed here are 
573 themselves unlikely to generate significant amounts of

574 aluminosilicate clays found in seafloor muds, the submarine

575 weathering of basalt and other volcanics can produce smectite

576 and other clay minerals (Kolla et al., 1976) and thus may be the

577 origin of some of the sediment seen here. Coccoliths and

578 planktonic forams also form a significant portion of the fine-

579 grained background sediment - these too are the result of

580 pelagic rain, and may also have been transported long distances

581 (van Sebille et al., 2015). Aragonite needles found in some

582 samples are produced in shallow water on or near carbonate

583 platforms (Milliman et al., 1993). This aragonite is therefore

584 interpreted to have been winnowed from the platform top

585 during times of flooding, as has been hypothesized by Jorry et

586 al (2016).

587 Coarser grainstone-packstone units found in core also

588 show evidence of a nearby shallow-water origin. Bioclastic

589 grains (e.g., corals and calcareous algae) are the skeletal

590 remains of organisms that live primarily within the photic zone;

591 they provide unambiguous evidence that at least part of the

592 sediments forming these beds are allochthonous, and come

593 from the tops of nearby platforms. The exact process by which

594 sediment is transferred off of the platform top is unknown,

595 however, wind-related or tide-related currents are both active

596 on the shallow water portion of platforms. Elsewhere, density

597 cascading has been proposed as a mechanism for the off- 
598 platform transfer of sediment (Wilson and Roberts, 1995), a

599 process which is not likely to be active here as it is dependent

600 on winter cold fronts that are not present in the Mozambique

601 Channel (Deutscher Wetterdienst, 2018).

602 The fining-upward profiles of some of these beds (e.g.,

603 those shown in Fig. 8A-E) are consistent with deposition as

604 turbidites (Shanmugam, 2000). Other depositional processes

605 may also occur: in core MOZ1-KS27, the size of mud clasts

606 within the main bed increases upward. This type of inverse

607 grading may occur in debrites (Mulder and Alexander, 2001),

608 and strongly resembles cohesive flow deposits described by

609 Lowe (1982). Inverse grading has been described previously on

610 ancient carbonate slopes (e.g., Mullins and Cook, 1986).

611 Ripped-up clasts of slope muds entrained within debris flows

612 are also a common component of carbonate slope deposits

613 (James and Jones, 2016). Fining-upward turbidites are also

614 found stratigraphically adjacent to the debris flow unit (Fig.

$6158 \mathrm{~A})$. Turbidite facies are clearly separate, but may be related to

616 the debris flow event (linked turbidites and debrites, c.f. Benn

617 \& Evans 2014; Talling et al. 2012). Sediments within these

618 types of gravity flows must ultimately originate from the

619 platform itself, as evidenced by the nature of constituent grains,

620 though the entraining turbidity current or debris flow may

621 originate lower on the slope. 
623 is a combination of hemipelagic sedimentation and gravity flow

624 deposits. However, larger-scale sediment transport processes

625 are also operating on platform slopes, as depositional units seen

626 in seismic profiles show evidence of mass transport on a

627 kilometer scale.

628

\subsubsection{Subsurface expression}

629

Sedimentary units and associated facies seen in seismic

630 lines and bathymetric data are interpreted to consist of three

631 primary types of deposits:

632

- Basin floor pelagites

633

- Mass transport deposits (MTDs)

- Channels, levees, and turbidite lobes

High-amplitude, parallel reflections on the basin floor

636 (Facies A) are interpreted to be the result of pelagic and

637 hemipelagic sedimentation processes that are continually

638 occurring in the deep sea (Pickering et al., 1986). This seismic

639 facies corresponds to the foraminiferal muds that are seen in

640 core. Thin carbonate turbidites may also be present within this

641 facies, but are likely to be only in the area immediately

642 surrounding each platform. Near Juan de Nova, the character of

643 these background sediments is more variable than elsewhere

644 (Fig. 10C); this is likely a result of their proximity to the

645 western slope of Madagascar. Here, the variety of slope-related 
646 sedimentary processes creates internal surfaces and topography

647 not seen in the abyssal basin floor elsewhere (Fig. 10D).

648 Seismic Facies B-C, characterized by low- or mixed-

649 amplitude chaotic reflections, are usually restricted to discrete

650 units and contain many of the criteria used to recognize mass

651 transport deposits (MTDs), as outlined in Posamentier and

652 Martinsen (2011). Based on the geometry of the unit, as well as

653 the amplitude, continuity, and the orientation of internal

654 reflections, these MTDs are interpreted to be the result of one

655 of several depositional processes. MTDs consisting of chaotic,

656 transparent reflections (Facies B) and those with chaotic, but

657 higher amplitude reflections (Facies C) are interpreted to be the

658 result of submarine debris flows originating on the platform

659 slope. Deposits with similar chaotic seismic character have also

660 been referred to as debris flows by Carter (2001), Posamentier

661 and Kolla (2003), and Joanne et al. (2013), among others. In

662 carbonates specifically, Principaud et al. (2015) interpret

663 chaotic seismic units as mass transport complexes with a debris

664 flow component, and Janson et al. (2011) interpret units

665 characterized by discontinuous, low-amplitude reflectionslso

666 interpreted as debris flows. Debris flow processes remove

667 original stratification during downslope movement, and have

668 the potential to travel long distances (Mulder and Cochonat,

669 1996), features consistent with the units seen here that extend

670 for several kilometers. The amplitude of the reflections that 
671 distinguishes between these facies is likely a product of the

672 lithologic heterogeneity of the source material. On the eastern

673 side of Juan de Nova, this facies contains large stratified and

674 convolute-bedded blocks on a scale of several hundred meters

675 (Fig. 10C), interpreted as large blocks of coherent or deformed

676 sediment entrained within the mass movement.

677 The basinward or platform-dipping reflections in some

678 units containing Facies D suggest that a different process is

679 responsible for their deposition. A unit on the northwestern side

680 of Glorieuses thins basinward and displays both progradational

681 and retrogradational internal geometries (Figs. 11A, 11B). This

682 unit is interpreted as a turbidite lobe, as deposits with these

683 types of geometries have been interpreted elsewhere as

684 turbidites (e.g., Gervais et al., 2006). It is likely the subsurface

685 expression of the type of lobate deposits seen on the current

686 seafloor elsewhere (e.g., on Bassas da India; Fig. 8A). On the

687 northwestern side of Glorieuses, the unit seen in Figure 12

688 contains a series of organized structures with platform-dipping

689 reflections that are expressed on the seafloor surface. These

690 deposits are interpreted as a large MTD with depositional

691 thrusts and pressure ridges (Fig 12) gliding along a subsurface

692 decollement. Such features are known to form due to the

693 compressional regime encountered during some downslope

694 mass movements (Posamentier and Martinsen, 2011; Alsop et

695 al., 2017), however, this is one of the first times they have been 
696 clearly documented in a predominantly carbonate system.

697 Sedimentary compression ridges similar to these have been

698 noted in analogous settings in the clastic realm - nearly

699 identical features are described in recent, submarine sediments

700 from multiple locations (e.g., Alfaro and Holz, 2014;

701 Moscardelli et al., 2006; Frey-Martínez et al., 2005; Hampton

702 and Lee., 1996; Joanne et al., 2013). Compressional features

703 cannot explain all seafloor ridges near Glorieuses, however;

704 smaller sediment waves are also present in the same area, and

705 some of the seafloor topography seen in Figure 2A may be

706 related to turbidity currents.

707 Transparent, continuous deposits in Facies E are form a

708 channel levee, and interpreted to be the result of the overbank

709 depositional processes associated with channelized sediment

710 gravity flows. The generally low-amplitude nature of these

711 deposits suggests that they are of uniform composition and

712 fine-grained, an interpretation confirmed by the predominance

713 of muds in core MOZ4-CS23 (Fig. 8D).

$714 \quad 5.1 .3$ Seafloor surface

715 Backscatter (reflectivity) data has been reliably shown to

716 predict sedimentological facies (Dartnell and Gardner, 2004),

717 grain size (Clarke et al., 1996; McGonigle and Collier, 2014),

718 and degree of induration of the seafloor (Mulder et al., 2017),

719 though has not been used previously to differentiate between

720 carbonate sands and muds. Here, high reflectivity values are 
interpreted to denote areas of submarine volcanism, erosional outcrops, and active sediment transfer where coarser-grained

723 (larger than silt-sized) facies are more abundant on the seafloor.

724 This assumption fits with observed geomorphology and is

725 preliminarily confirmed by core data. Backscatter data shows

726 that active deposition of coarse-grained material is currently

727 taking place through feeder channels that funnel sediment to

728 the basin floor (Figs. 2 and 3). High reflectivity values are

729 interpreted to be the result of carbonate sands (grainstones) on

730 the floors of incised channels, which respond differently to

731 acoustic soundings than surrounding muds. Although lithified

732 volcanic outcrops are also highly reflective, these are easily

733 distinguished from linear sediment pathways. High-reflectivity

734 sediments within channels may terminate on the basin floor in a

735 lobe, and channel forms may be bounded by elevated levees

736 (Fig. 9D-E). Undulatory surface morphologies within some

737 channels are interpreted as cyclic steps (c.f. Covault et al.,

738 2017). These types of bedforms, lobes and levees are associated

739 with deposition from turbidity currents (Shanmugam, 2000),

740 and this is interpreted to be the primary process of sediment

741 transfer from the platform top. Channel forms without

742 increased reflectivity are interpreted as inactive, as is the case

743 in the leveed channel noted in Fig. 9C. This channel and others

744 like it may have been cut off from active deposition in the past,

745 a hypothesis supported by the lack of recent sandy deposits in 
the adjacent core (MOZ4-CS23). Individual channels may

747 therefore have a finite lifespan, and active channels and lobes

748 may switch with changes in sediment availability.

$749 \quad 5.2$ Controls on deposition and geomorphology

750 The nature of the volcanic edifice underlying each

751 platform ultimately influences the size, height, and overall

752 gradient of the slope profile, all of which influence the slope

753 depositional architecture. Volcanic cone morphologies lead to

754 an overall smaller platform top size, limiting the volume of

755 bioclastic carbonate sediment that can be produced and thus

756 reducing the available sediment supply to slopes. High

757 gradients in the upper slope lead to little carbonate deposition;

758 the majority of slope sedimentation takes place where gradients

759 are less than $10^{\circ}$. This upper slope bypass inhibits progradation

760 and lateral expansion of the platform top. Slope steepness is

761 also likely responsible for straight channel morphologies (Clark

762 et al., 1992) and the development of basin-floor fan systems, a

763 type of deposit rarely seen in modern carbonate settings

764 (Payros and Pujalte, 2008). The abundance of MTDs on the

765 lower slope and proximal seafloor may also be influenced by

766 slope steepness, although past studies (e.g., Hühnerbach and

767 Masson, 2004) note that the number of slope failures are is

768 relatively independent of inclination, even in volcanic islands.

769 Active regional tectonics may also directly influence platform

770 morphology (and thus deposition), as in the fault-generated 
771 subaqueous terrace on Bassas da India. Processes occurring on

772 the terrace may likely affect the sedimentary character of

773 platform sediments; large sand dunes (Fig. 4B, inset; lithology

774 confirmed by sediment samples) suggest that sediments may be

775 winnowed and transported by bottom currents atop the terrace

776 before subsequently moving further downslope.

777 The direction and intensity of dominant trade winds have

778 long been known to have an effect on the facies distribution on

779 carbonate platforms (Dravis and Wanless, 2017) including on

780 Glorieuses (Jorry et al., 2016; Prat et al., 2016). In the Iles

781 Eparses, most platform tops show some degree of wind-related

782 asymmetry, especially on Glorieuses and Juan de Nova.

783 Platform tops also differ in terms of their geomorphology,

784 which likely has some influence over the nature and

785 distribution of slope sediments. Open platform tops without a

786 fringing reef (Glorieuses and Juan de Nova) have a submarine

787 bank with no barriers between the top and slope break, a

788 morphology that promotes continuous deposition and sediment

789 transfer (Fig. 2). Enclosed platform tops (Bassas da India) have

790 an interior lagoon with a mostly continuous fringing reef,

791 preventing continual transferal of large amounts of sediment

792 from the inner platform to the slope, and possibly affecting the

793 sedimentological character of platform top exports by confining

794 platform-top muds (Fig. 3). On the top of Europa, sediment

795 transfer is localized, showing a strong directionality to 
796 sediment export in the form of a wide tidal channel. This

797 channel is clearly the origin point for the largest single channel

798 on the slope (labeled 'TC' on Fig. 4C). However, backscatter

799 data (Fig. 3D) do not suggest that active sedimentation is

800 appreciably increased within this specific channel axis when

801 compared to the many other channels visible surrounding the

802 island. Future studies of platform top sedimentology are needed

803 to fully understand the way that sediment export is affected by

804 platform top elements.

805 Wind-related asymmetry extends to the slope as well-

806 the leeward sides of carbonate platforms elsewhere have been

807 established to have their morphology affected by off-platform

808 sediment transport (e.g., Hine et al., 1981). Here, leeward sides

809 are generally smoother, with fewer high-relief outcrops. This is

810 interpreted to be a product of increased sedimentation, which

811 would promote faster erosion of any volcanic highs or remnant

812 sedimentary outcrops, and would infill depressions and low

813 areas with sediment. Windward sides of platforms are

814 sometimes more rugose than leeward sides. This can also be

815 attributed to increased abundance of outcrops of underlying

816 basement, as well as from steep-sided arcuate slope failures.

817 Decreased windward sedimentation may lead to oversteepened,

818 sediment-starved windward slopes, which are more prone to

819 failure.

$820 \quad 5.3$ Summary and facies model 
822 from an idealized scenario, the character and distribution of

823 sedimentary facies seen here is significantly different from

824 previously established models of carbonate slopes elsewhere.

825 Past models have generally not focused on steep, volcanic-

826 cored platforms, however, these settings are clearly responsible

827 for the generation of substantial amounts of carbonate

828 sediment, and have a unique set of depositional features when

829 compared to those elsewhere. The geomorphology, depositional

830 elements, and sedimentary processes seen in the Iles Eparses

831 are synthesized in a facies model shown in Figure 13.

832 In summary, sediment transfer to the deep sea in the Iles

833 Eparses is a combination of processes at a variety of scales.

834 Carbonate sediments on the platform top are transported onto

835 the broad, steep upper slope through the action of wind- or tide-

836 generated water movement, shallow currents, or density

837 cascading (Fig. 13A). The slope becomes increasingly

838 channelized basinward, with sediments moving down straight

839 channel axes in gravity flows. Carbonate grainstones-

840 packstones are ultimately deposited in the lower slope or

841 proximal basin in the form of gravity flow deposits (turbidites

842 and debrites), including levee and overbank deposits, where

843 they are interbedded with hemipelagic foraminiferal muds.

844 These interbedded gravity flow deposits and background muds

845 (and possibly basement volcanics) may move further 
846 downslope together in the form of large-scale mass transport

847 deposits that originate on the slope itself (Fig. 13B). MTDs

848 may in turn be subsequently reworked as new channels incise

849 into lower slope sedimentary deposits (Fig. 13C). Any given

850 slope deposit may therefore be the result of multiple

851 sedimentation processes, and a range of depositional elements

852 resulting from several different processes may be present on the

853 seafloor at any given time. Figure 13 shows a composite sketch

854 combining many of the observed geomorphologic and

855 depositional features seen across platforms, and general

856 characteristics are summarized in the chart in Table 3.

8575.4 Implications

858 The synthesis of observed features and processes shown

859 in Figure 13 is one of the first detailed facies models for

860 sedimentary deposition on the slopes of carbonate atolls and

861 atoll-like carbonate platforms. It can be compared with similar

862 block diagrams on other carbonate slopes (e.g. Betzler et al.,

863 2014, Grammer and Ginsberg, 1992, Mulder et al., 2017,

864 Mullins and Cook, 1986, Mullins et al., 1984, and Payros and

865 Pujalte, 2008, among others). Although these are very different

866 types of carbonate platforms from those discussed here, such a

867 comparison is essential in determining which aspects of

868 carbonate deposition are more universal, and highlights the

869 differences between the settings discussed here and more

870 'traditional' carbonate platforms. In addition, facies on the 
871 slopes of these platforms differ from those on other volcanic

872 islands. The island of La Réunion (Indian Ocean), for example,

873 is characterized by a steep-sided central volcanic cone rather

874 than a flat, carbonate-dominated platform top. Facies models

875 developed on the submarine slopes of La Réunion therefore

876 lack the extensive carbonate deposits seen here, and are instead

877 dominated by large-scale flank collapses, lava flow platforms

878 and deltas, and volcaniclastic fan systems (Babonneau et al.,

879 2011; Saint-Ange et al., 2013; Sisavath et al., 2011).

880 Elsewhere, the flanks of Madeira Archipelago (a series of

881 volcanic islands in the Atlantic Ocean) are also dominated by

882 numerous large, arcuate slope failures, as well as numerous

883 radial gully-channel systems more similar to those seen here

884 (Quartau et al., 2018). These channels, however, often show a

885 well-developed dendritic pattern in map view, and coalesce into

886 longer, larger channels that extend much further from the

887 islands than those in the Iles Eparses.

888 Of note in the Iles Eparses are the presence of clear,

889 unambiguous channel systems with lobate basin-floor fans.

890 This type of lobate fan system has rarely been described in

891 other modern carbonate settings: Payros and Pujalte (2008)

892 state that "Calciclastic submarine fans are rare in the

893 stratigraphic record and no bona fide present-day analogue has

894 been described to date." Mullins and Cook (1986) also note the

895 paucity of unambiguous examples in the geologic record, and 
896 James and Jones (2016) note that submarine fans do not

897 typically form on carbonate slopes because of the linear, rather

898 than point-sourced, nature of slope profiles. Terminal fans seen

899 in the Iles Eparses are likely present because sediments are

900 concentrated into relatively few active channels that reach the

901 basin floor. Platform-derived sediment is distributed over a

902 relatively small area, resulting in more focused distributary

903 systems and promoting point-sourcing of deposition.

904 Although the deposits seen here are relatively recent in

905 origin, the distribution and character of these sediments may be

906 used as an analog for deposits elsewhere. Core taken on lower

907 slopes almost always include some component of carbonate

908 grainstones-packstones, a facies with more potential as a

909 conventional hydrocarbon reservoir than the periplatform muds

910 that make up the majority of core in inter-channel areas, MTDs,

911 and levees. Goldstein et al. (2012) note the difference in

912 reservoir potential between dispersed- and focused-flow

913 carbonate slope systems in the Miocene of Spain; the Iles

914 Eparses deposits are more similar to the latter. These types of

915 small isolated platforms therefore have a different reservoir

916 potential and sediment distribution than other, larger platforms

917 with more dispersed depositional systems. The higher reservoir

918 potential of more concentrated focused-flow grainstones should

919 be tempered by the overall smaller volume, smaller distribution

920 radius, and lower preservation potential of these types of 
settings; the geologic record of atolls and carbonate platforms

922 atop deep sea volcanoes is relatively sparse.

923

924

925

926

927

928

929

930

931

932

933

934

935

936

937

938

939

940

941

942

943

944 facies often taking the form of chaotic units interpreted as 945 debris flows. Depositional thrusting and associated pressure

\section{Conclusions}

The Iles Eparses atolls, islands, and platforms are situated on isolated deepwater volcanic pedestals in and around the Mozambique Channel, making them genetically different from other, more well-known carbonate settings. This study provides a first look into the nature of carbonate slope sedimentation in this unique, little-known depositional environment, and presents the first detailed facies model for the types of atoll and atoll-like platforms discussed here. Slope sediments are a product of a range of gravity-dominated depositional processes, including hemipelagic rain, slope failure and downslope mass transport, and gravity flows (turbidites and debrites). Inherited topography of the underlying volcanic pinnacles results in steep upper slope gradients where little sedimentation takes place and arcuate slope failure scars are locally common. Platformderived carbonates may be channelized in the lower slope, forming, in places, relatively straight channel systems that extend for tens of kilometers and may terminate in basin-floor lobes, a relatively rare occurrence in modern-day carbonate settings. Elsewhere on the lower slope, turbidites and mass transport deposits are present, with the subsurface seismic 
946 ridges are also present in some lower slope deposits. Slopes are

947 usually asymmetric with respect to predominant wind direction,

948 with leeward slopes usually having a lower rugosity than

949 windward slopes and more spatially extensive toe-of-slope

950 deposition. The lack of data in settings analogous to the Iles

951 Eparses underscores the need for further research, and shows

952 the importance of the observations reported here in expanding

953 the known spectrum of depositional carbonate depositional

954 environments.

955 7. Acknowledgements

956 The oceanographic expeditions PTOLEMEE, PAMELA-

957 MOZ1 and PAMELA-MOZ4 and Elda Miramontes' fellowship

958 were co-funded by TOTAL and IFREMER as part of the

959 PAMELA (Passive Margin Exploration Laboratory) scientific

960 project. This work was supported by the "Laboratoire

961 d'Excellence" LabexMER (ANR-10-LABX-19) and co-funded

962 by a grant from the French government under the program

963 "Investissements d'Avenir". Thanks to Joseph Ronzier for

964 writing and executing the Python script used in calculating

965 slope rugosity. Thanks to Simon Courgeon for additional data

966 contributions and helpful discussions related to this project,

967 Sandrine Cheron and Audrey Boissier for XRD analysis, and

968 Nicolas Gayet for SEM assistance. We also thank the captains

969 and crews of the RVs Atalante and Pourquoi Pas? during the

970 cruises where this data was collected. 
971 Figure Captions

972 Table 1: General dimensions and associated volumes of

973 selected slope failure scars on Juan de Nova. Wedge diagram

974 shows conceptual method of volumetric calculation.

975 Table 2: Interpreted seismic facies found in lower slopes and

976 proximal basins. Interpretations are based on the amplitude,

977 orientation, and bounding relationships of seismic reflectors

978 within seismic units.

979 Table 3: Chart summarizing scale and character of selected

980 depositional elements observed in this study.

981 Figure 1: A) Location map of platforms and other geographic

982 and geologic features mentioned in this paper. Oceanic

983 circulation from Brietzke et al. (2017). COM-Comoros Islands;

984 MAY-Mayotte Island; GLO- Glorieuses Islands; JDN-Juan de

985 Nova; DR-Davie Ridge; ZV-Zambezi Valley ; BDI-Bassas da

986 India; EUR-Europa. B) Present-day dominant wind directions

987 from Metéo France, sourced from over 5000 individual

988 measurements from weather stations on the islands. Bassas da

989 India has no weather station, but is situated close enough to Ile

990 Europa that wind directions are not appreciably different (see

991 location in Figure 1A).

992 Figure 2: Detailed bathymetric and backscatter maps of slopes

993 of Iles Eparses platforms Glorieuses (A, B) and Juan de Nova

994 (C, D). Bathymetric maps are an overlaid combination of

995 absolute seafloor depth (color) and slope gradient (greyscale), 
996 allowing both the slope relief and seafloor topography to be

997 seen. Reflectivity maps use an arbitrary, sliding-scale color bar

998 to best differentiate sedimentological and geomorphologic

999 features. GG-Grande Glorieuse Island.

1000 Figure 3: Detailed bathymetric and backscatter/reflectivity

1001 maps of slopes of Iles Eparses platforms Bassas da India and

1002 Europa. Same parameters as Figure 2. A, B) Bassas da India; C,

1003 D) Europa, TC-tidal channel.

1004 Figure 4: Three-dimensional views of submarine platform

1005 slopes, focusing on slope morphology. Color gradient adjusted

1006 for each platform. A) Southeast-looking view of Glorieuses,

1007 showing the platform top, Glorieuses terrace and the linear

1008 escarpment most prominent on the northwestern side

1009 (magnified view in inset). B) Northward-looking view of

1010 Bassas da India, showing large submarine terrace and its profile

1011 and associated features, notably sand dunes and gullies found

1012 on the terrace surface in 350-600 meters water depth (insets).

1013 C) Southeastern-looking view of Europa, showing strike and

1014 dip profiles and location of seismic line in Figure 4D. Channel

1015 floor visible in both bathymetric and seismic data marked with

1016 an asterisk. Also of note is the steep, smooth upper slope

1017 surface, visible here on the leeward side of the platform. D)

1018 Europa seismic line 076 (PTO-mig076_v1500_g0). This line

1019 shows the relatively thin nature of sedimentary deposits in the 
1020

1021

1022

1023

1024

1025

1026

1027

1028

1029

1030

1031

1032

1033

1034

1035

1036

1037

1038

1039

1040

1041

1042

1043

1044

mid-slope, the seismic character of the volcanic basement, and the higher-amplitude reflections in channel floors.

Figure 5: A-B): Evidence of slope failure on Juan de Nova; A)

Leeward slope, showing generally smooth upper slope surface and two large arcuate scarps, denoted 1 and 2 in Figure 5D. B)

Windward slope, with several discrete scarps highlighted (numbers 3-6). Approximate volumetric calculations for each numbered scarp shown in Table 1. C) Quantitative rugosity analysis of Juan de Nova upper slope. $1^{\text {st }}$ part shows conceptual method of quantification, second part applies the same method to the 600-m contour on Juan de Nova platform. On Juan de Nova, the windward side of the platform is significantly more rugose than the windward side.

Figure 6: Examples of slope failure and/or erosion on Bassas da India and Europa, with along-strike profiles and dimensions. Figure 7: A) Seismic line 079 (PTO-mig079_v1500_g0), taken along the leeward side of Europa, showing sedimentary nature of the lower slope. The line is an oblique dip line, crossing channels and levees seen in Figures 8D and 8E, and clearly showing their contact with the underlying basement. B-D) Bathymetric profiles for the windward and leeward slopes of platforms. Bassas da India not included due to lack of data coverage on the windward side. Note extended lower slope on each leeward side; windward slopes often have a steeper descent to the basin floor. 
1045 Figure 8: Core data from the lower slopes and proximal basins

1046 of Iles Eparses. Exact locations of core shown in Figure 2. A-

1047 D) Lithologies and core photos from four seafloor piston cores.

1048 Core MOZ4-CS23 (D) contains an additional 23 meters above

1049 the selected section that is almost entirely composed of

1050 background foraminiferal ooze. (A) taken at $3089 \mathrm{~m}$; (B) 3167

$1051 \mathrm{~m}$; (C) $1909 \mathrm{~m}$; (D) $2852 \mathrm{~m}$. E) Grain-size profiles of the

1052 carbonate grainstone-packstone beds marked in red in above

1053 logs. F) Compositional data for selected intervals within

1054 carbonate grainstone-packstone beds. Locations denoted in A-

1055 D. Data shown only includes identifiable grains; unidentified

1056 grains constitute $30-40 \%$ of total grains observed. G) SEM

1057 images of carbonate grainstones in core MOZ1-KS04, interval

$1058 \quad 649-650 \mathrm{~m}$, at the base of a relatively thick carbonate sand unit.

1059 Abbreviations: BF-benthic foraminifer; CA-calcareous algae;

1060 Ec-echinoid; Fo-Foraminifer; Ga-gastropod; PF-planktonic

1061 foraminifer. H) Analysis of muds/foraminiferal oozes; left side:

1062 SEM images; AN-aragonite needles; CM-clay minerals; Co-

1063 Coccolith. Right side: EDS spectra and XRD mineralogy of

1064 selected intervals.

1065 Figure 9: Examples of channels and channel-related features on

1066 Iles Eparses slopes. A) Reflectivity map of northeastern side of

1067 Glorieuses, showing numerous sub-parallel active channels that

1068 do not terminate in lobe structures. B) and C) are overlays of

1069 reflectivity and slope data; B) Northwestern side of Bassas da 
India, showing bifurcating channels, some of which terminate

1071 in a lobe. Image is an overlay of reflectivity and slope data. C)

1072 Northern side of Europa. Inactive channel crossed by seismic

1073 lines in $\mathrm{D}$ and $\mathrm{E}$ is outlined with dashed line. Other, active

1074 channels have higher backscatter values and fan outward at the

1075 slope base. D) Seismic strike line on the north side of Europa

1076 showing channel-levee complex. Note levee transparency,

1077 higher-amplitude asymmetric overbank deposits, and central

1078 channel. E) Interpretation of (D)

1079 Figure 10: Lower slope seismic lines and interpretations.

1080 Description of seismic facies in text and in Table 2. Exact

1081 locations of lines shown in Figures 2 and 3. A) Bassas da India

1082 line 017 (PTO-mig017_v1500). B) Interpretation of seismic

1083 line above in (A). C) Juan de Nova line 234 (PTO-

1084 mig234_v1500_g0). D) Interpretation of seismic line above in

1085 (C). Colors delineate individual stratigraphic units, similar

1086 colors denote related units.

1087 Figure 11: Lower slope seismic lines and interpretations,

1088 continued. A) Glorieuses Line 315 (mig315_v1500_g0). B)

1089 Interpretation of seismic line above in (A).

1090 Figure 12: Glorieuses Line 319 (mig319_v1500_g0) and notes

1091 on interpretation.

1092 Figure 13: A-C) Simplified diagram of sedimentation processes

1093 observed in core, seafloor bathymetry, and seismic data. A)

1094 Turbidite deposition resulting in interbedded carbonate 
1095 grainstone-packstones and seafloor muds B) Upper-middle

1096 slope failure, remobilizing previously deposited sediments

1097 (potentially including parts of the lithified platform) and

1098 redistributing them to the lower parts of the slope in the form of

1099 MTDs. C) Further deposition of carbonate grainstones-

1100 packstones in turbidites. Channelized deposits may erode into

1101 past MTDs and rework previously deposited material. D)

1102 Facies model that summarizes depositional elements and

1103 sedimentation processes in the Iles Eparses. Figure represents a

1104 synthesis of data from bathymetric, reflectivity, and seismic

1105 surveys of multiple platforms. Schematic only; not to scale.

1106

1107

1108

1109 
1111 Alfaro, E., Holz, M., 2014. Seismic geomorphological analysis

1112 of deepwater gravity-driven deposits on a slope system of the

1113 southern Colombian Caribbean margin. Marine and Petroleum

1114 Geology 57, 294-311.

1115 Alsop, G.I., Marco, S., Levi, T., Weinberger, R., 2017. Fold

1116 and thrust systems in Mass Transport Deposits. Journal of

1117 Structural Geology, 94, 98-115.

1118 Amblas, D., Ceramicola, S., Gerber, T.P., Canals, M., Chiocci,

1119 F.L., Dowdeswell, J.A., Harris, P.T., Huvenne, V.A., Lai, S.Y.,

1120 Lastras, G. and Iacono, C.L., Micalle, A., Mountjoy, J.J., Paull,

1121 C.K., Puig, P., and Sanchez-Vidal, A. 2018. Submarine

1122 canyons and gullies. In: Micallef, A., Krastel S., and Savini A.

1123 (eds) Submarine Geomorphology. 251-272, Springer Geology.

1124 Springer, Cham.

1125 Babonneau, N., Delacourt, C., Cancouët, R., Sisavath, E.,

1126 Bachèlery, P., Mazuel, A., Jorry, S.J., Deschamps, A.,

1127 Ammann, J. and Villeneuve, N., 2013. Direct sediment transfer

1128 from land to deep-sea: Insights into shallow multibeam

1129 bathymetry at La Réunion Island. Marine Geology, 346, 47-57.

1130 Bassias, Y., Roberts, G., Christoffersen, T., 2016. The nature of 1131 the crust offshore East Coast Africa When geology and seismic 
1132 meet potential fields in the search for hydrocarbons. East

1133 Africa: From Research to Reserves, Extended Abstract, The

1134 Geological Society of London 13-15 April 2016, 1-12.

1135 Battistini, R., Cremers, G., 1972. Geomorphology and

1136 vegetation of Iles Glorieuses. Smithsonian Institution. Atoll

1137 Research Bulletin 159, 27 p.

1138 Battistini, R., Gayet, J., Jouannic, C., Labracherie, M.,

1139 Peypouquet, J.P., Pujol, C., Pujos-Lamy, A., Turon, J.L., 1976.

1140 Etude des sédiments et la microfaune des îles Glorieuses (Canal

1141 de Mozambique). Cahiers ORSTOM, Série Géologie 8, 147 -

1142171.

1143 Benn, D., Evans, D.J., 2014. Glaciers and glaciation.

1144 Routledge, 816 p.

1145 Berthois L., Battistini, R., 1969, Etude Sedimentologique de

1146 L'Ile Europa, Madagascar Revue de Geographie 15, 1-52.

1147 Betzler, C., Lindhorst, S., Eberli, G. P., Lüdmann, T., Möbius,

1148 J., Ludwig, J., Schutter, I., Wunsch, M., Reijmer, J., Hübscher,

1149 C., 2014. Periplatform drift: the combined result of contour

1150 current and off-bank transport along carbonate platforms.

1151 Geology 42, 871-874. 
1152 Betzler, C., Hübscher, C., Lindhorst, S., Lüdmann, T., Reijmer,

1153 J.J. and Braga, J.C., 2016. Lowstand wedges in carbonate

1154 platform slopes (Quaternary, Maldives, Indian Ocean). The

1155 Depositional Record, 2, pp.196-207.

1156 Blomeier, D.P.G., Reijmer, J. J., 2002. Facies architecture of an

1157 Early Jurassic carbonate platform slope (Jbel Bou Dahar, High

1158 Atlas, Morocco). Journal of Sedimentary Research 72, 462-

1159475.

1160 Breitzke, M., Wiles, E., Krocker, R., Watkeys, M.K., Jokat, W.,

1161 2017. Seafloor morphology in the Mozambique Channel:

1162 evidence for long-term persistent bottom-current flow and

1163 deep-reaching eddy activity. Marine Geophysical Research 38,

$1164 \quad 241-269$.

1165 Carter, L., 2001. A large submarine debris flow in the path of

1166 the Pacific deep western boundary current off New Zealand.

1167 Geo-Marine Letters, 21, 42-50

1168 Clark, J.D., Kenyon, N.H., Pickering, K.T., 1992. Quantitative

1169 analysis of the geometry of submarine channels: implications

1170 for the classification of submarine fans. Geology, 20, 633-636.

1171 Clarke, J.E.H., Mayer, L.A. and Wells, D.E., 1996. Shallow-

1172 water imaging multibeam sonars: a new tool for investigating 
1173 seafloor processes in the coastal zone and on the continental

1174 shelf. Marine Geophysical Researches, 18, 607-629.

1175 Courgeon, S., Jorry, S.J., Camoin, G.F., BouDagher-Fadel,

1176 M.K., Jouet, G., Révillon, S., Bachèlery, P., Pelleter, E.,

1177 Borgomano, J., Poli, E., Droxler, A.W., 2016. Growth and

1178 demise of Cenozoic isolated carbonate platforms: New insights

1179 from the Mozambique Channel seamounts (SW Indian Ocean).

1180 Marine Geology 380, 90-105.

1181 Courgeon, S., Jorry, S.J., Jouet, G., Camoin, G., BouDagher-

1182 Fadel, M.K., Bachèlery, P., Caline, B., Boichard, R., Révillon,

1183 S., Thomas, Y. Thereau, E., 2017. Impact of tectonic and

1184 volcanism on the Neogene evolution of isolated carbonate

1185 platforms (SW Indian Ocean). Sedimentary Geology 355, 114-

1186131.

1187 Covault, J.A., Kostic, S., Paull, C.K., Sylvester, Z., Fildani, A.,

1188 2017. Cyclic steps and related supercritical bedforms: building

1189 blocks of deep-water depositional systems, western North

1190 America. Marine Geology, 393, 4-20.

1191 Dartnell, P., Gardner, J.V., 2004. Predicting seafloor facies

1192 from multibeam bathymetry and backscatter data.

1193 Photogrammetric Engineering \& Remote Sensing 70, 1081-

11941091. 
1195 Deutscher Wetterdienst, 2018, Klimatafel von Juan de Nova

1196 (Insel), Iles Desirades / Indischer Ozean / Frankreich

1197 https://www.dwd.de/DWD/klima/beratung/ak/ak_619700_kt.pd

1198 f. Retrieved June 20, 2018.

1199 Dravis, J.J., Wanless, H.R., 2017. Impact of strong easterly

1200 trade winds on carbonate petroleum exploration-Relationships

1201 developed from Caicos Platform, southeastern Bahamas.

1202 Marine and Petroleum Geology 85, 272-300.

1203 Dunbar, G.B. and Dickens, G.R., 2003. Late Quaternary

1204 shedding of shallow-marine carbonate along a tropical mixed

1205 siliciclastic-carbonate shelf: Great Barrier Reef, Australia.

1206 Sedimentology, 50, 1061-1077.

1207 Förster, R., 1975. The geological history of the sedimentary

1208 basin of southern Mozambique, and some aspects of the origin

1209 of the Mozambique Channel. Palaeogeography,

1210 Palaeoclimatology, Palaeoecology 17, 267-287.

1211 Frey Martinez, J., Cartwright, J., Hall, B., 2005. 3D seismic

1212 interpretation of slump complexes: examples from the

1213 continental margin of Israel. Basin Research, 17, 83-108.

1214 Gervais, A., Savoye, B., Mulder, T., Gonthier, E., 2006. Sandy

1215 modern turbidite lobes: a new insight from high resolution

1216 seismic data. Marine and Petroleum Geology, 23, 485-502. 
1217 Gischler, E., 2011. Sedimentary facies of Bora Bora, Darwin's

1218 type barrier reef (Society Islands, South Pacific): the

1219 unexpected occurrence of non-skeletal grains. Journal of

1220 Sedimentary Research, 81,1-17.

1221 Goldstein, R.H., Franseen, E.K., Dvoretsky, R.A., Sweeney,

1222 R.J., 2012. Controls on focused-flow and dispersed-flow

1223 deepwater carbonates: Miocene Agua Amarga Basin, Spain.

1224 Journal of Sedimentary Research 82, 499-520.

1225 Grammer, G.M., Ginsburg, R.N., 1992. Highstand versus

1226 lowstand deposition on carbonate platform margins: insight

1227 from Quaternary foreslopes in the Bahamas. Marine Geology $1228103,125-136$.

1229 Guillaume, M.M., Reyss, J.L., Pirazzoli, P.A., Bruggemann, 1230 J.H., 2013. Tectonic stability since the last interglacial offsets 1231 the Glorieuses Islands from the nearby Comoros archipelago. 1232 Coral Reefs 32, 719-726.

1233 Hampton, M., and Lee, H., 1996. Submarine Landslides, 1234 Reviews of Geophysics 34, 33-59.

1235 Harris, D.L., Webster, J.M., De Carli, E.V., Vila-Concejo, A., 1236 2011. Geomorphology and morphodynamics of a sand apron, 1237 One Tree reef, southern Great Barrier Reef. Journal of Coastal 1238 Research, 64, 760. 
1239

1240

1241

124

1243 Hallock, P., Belknap, D.F., Gonzales, J.L., Neumann, A.C.,

1244 Snyder, S.W., 1992. Megabreccia shedding from modern, low-

1245 relief carbonate platforms, Nicaraguan Rise. GSA Bulletin,

$1246104,928-943$.

1247 Hühnerbach, V. and Masson, D.G., 2004. Landslides in the

1248 North Atlantic and its adjacent seas: an analysis of their

1249 morphology, setting and behaviour. Marine Geology, 213, 343-

1250362.

1251 James, N. P., Jones, B., 2016. Origin of Carbonate Sedimentary

1252 Rocks. John Wiley \& Sons. 320 p.

1253 Janson, X., Kerans, C., Loucks, R., Marhx, M.A., Reyes, C.

1254 and Murguia, F., 2011. Seismic architecture of a Lower

1255 Cretaceous platform-to-slope system, Santa Agueda and Poza

1256 Rica fields, Mexico. AAPG bulletin, 95, 105-146.

1257 Joanne, C., Lamarche, G., Collot, J.Y., 2013. Dynamics of

1258 giant mass transport in deep submarine environments: the

1259 Matakaoa Debris Flow, New Zealand. Basin Research, 25, 471-

1260488. 
1261 Johnston, S.T., Thorkelson, D.J., 2000. Continental flood

1262 basalts: episodic magmatism above long-lived hotspots. Earth

1263 and Planetary Science Letters, 175, 247-256.

1264 Jorry, S., 2014. PTOLEMEE cruise, RV L'Atalante.

1265 http://dx.doi.org/10.17600/14000900

1266 Jorry, S.J., Camoin, G.F., Jouet, G., Le Roy, P., Vella, C.,

1267 Courgeon, S., Prat S., Fontanier C., Paumard V., Boulle J.,

1268 Caline B., Borgomano, J., 2016. Modern sediments and

1269 Pleistocene reefs from isolated carbonate platforms (Iles

1270 Eparses, SW Indian Ocean): A preliminary study. Acta

1271 Oecologica, 72, 129-143.

1272 Jouet, G., Deville, E., 2015. PAMELA-MOZ04 cruise, RV

1273 Pourquoi Pas ?. http://dx.doi.org/10.17600/15000700

1274 Kolla, V., Henderson, L. and Biscaye, P.E., 1976. Clay

1275 mineralogy and sedimentation in the western Indian Ocean.

1276 Deep Sea Research and Oceanographic Abstracts 23, 949-961.

1277 Lort, J.M., Limond, W.Q., Segoufin, J., Patriat, P., Delteil, J.R.,

1278 Damotte, B., 1979. New seismic data in the Mozambique

1279 Channel. Marine Geophysical Research, 4, 71-89.

1280 Lowe, D.R., 1982. Sediment gravity flows: II Depositional

1281 models with special reference to the deposits of high-density 

297.

1284 McGonigle, C. and Collier, J.S., 2014. Interlinking backscatter, 1285 grain size and benthic community structure. Estuarine, Coastal 1286 and Shelf Science, 147, 123-136.

1287 McIlreath, I.A., James, N.P., 1978. Facies models 13.

1288 Carbonate slopes. Geoscience Canada, 5, 189-199.

1289 Météo France, 2017.

1290 https://publitheque.meteo.fr/Donnees/DESC170531171564028

1291 9.KEYu07f7D3UO9xudD2U2fU9.html 1/2

1292 Milliman, J.D., Freile, D., Steinen, R.P. and Wilber, R.J., 1993.

1293 Great Bahama Bank aragonitic muds: mostly inorganically

1294 precipitated, mostly exported. Journal of Sedimentary

1295 Research, 63, 589-595.

1296 Moscardelli, L., Wood, L., Mann, P., 2006. Mass-transport

1297 complexes and associated processes in the offshore area of

1298 Trinidad and Venezuela. AAPG Bulletin, 90, 1059-1088.

1299 Mulder, T., Alexander, J., 2001. The physical character of

1300 subaqueous sedimentary density flows and their deposits.

1301 Sedimentology, 48, 269-299. 
1302

1303

1304 Mulder, T., Joumes, M., Hanquiez, V., Gillet, H., Reijmer,

130

1306

1307 slope morphology revealing sediment transfer from bank-to-

1308 slope (Little Bahama Bank, Bahamas). Marine and Petroleum

1309 Geology, 83, 26-34.

1310

1311 alternatives to the submarine fan model for paleoenvironmental

1312 analysis and hydrocarbon exploration. Sedimentary Geology,

$131348,37-79$.

1314 Mullins, H.T., Heath, K.C., Buren, H., Newton, C.R., 1984.

1315 Anatomy of a modern open-ocean carbonate slope: northern

1316 Little Bahama Bank. Sedimentology, 31, 141-168.

1317 Olu, K., 2014. Rapport de fin de mission campagne Pamela-

1318 MOZ01. http://dx.doi.org/10.17600/14001000

1319 Payros, A., Pujalte, V., 2008. Calciclastic submarine fans: An

1320 integrated overview. Earth-Science Reviews, 86, 203-246.

1321 Pickering, K., Stow, D., Watson, M. and Hiscott, R., 1986.

1322 Deep-water facies, processes and models: a review and 
1323 classification scheme for modern and ancient sediments. Earth-

1324 Science Reviews, 23, 75-174.

1325 Posamentier, H.W. and Kolla, V., 2003. Seismic

1326 geomorphology and stratigraphy of depositional elements in

1327 deep-water settings. Journal of Sedimentary Research, 73, 367-

1328388.

1329 Posamentier, H.W., Martinsen, O.J. and Shipp, R.C., 2011. The

1330 character and genesis of submarine mass-transport deposits:

1331 insights from outcrop and 3D seismic data. In: Shipp, R.C.,

1332 Weimer, P., and Posamentier, H.W. (eds.), Mass-transport

1333 deposits in deepwater settings: Society for Sedimentary

1334 Geology (SEPM) Special Publication 96, 7-38.

1335 Prat, S., Jorry, S.J., Jouet, G., Camoin, G., Vella, C., Le Roy,

1336 P., Caline, B., Boichard, R., Pastol, Y., 2016. Geomorphology

1337 and sedimentology of a modern isolated carbonate platform:

1338 The Glorieuses archipelago, SW Indian Ocean. Marine

1339 Geology, 380, 272-283.

1340 Principaud, M., Mulder, T., Gillet, H. and Borgomano, J., 2015.

1341 Large-scale carbonate submarine mass-wasting along the

1342 northwestern slope of the Great Bahama Bank (Bahamas):

1343 Morphology, architecture, and mechanisms. Sedimentary

1344 Geology, 317, 27-42. 
1345 Quartau, R., Ramalho, R.S., Madeira, J., Santos, R., Rodrigues,

1346 A., Roque, C., Carrara, G. and da Silveira, A.B., 2018.

1347 Gravitational, erosional and depositional processes on volcanic

1348 ocean islands: Insights from the submarine morphology of

1349 Madeira Archipelago. Earth and Planetary Science Letters, 482,

$1350 \quad 288-299$

1351 Raharimahefa, T. and Kusky, T.M., 2010. Environmental

1352 monitoring of Bombetoka Bay and the Betsiboka Estuary,

1353 Madagascar, using multi-temporal satellite data. Journal of

1354 Earth Science, 21, 210-226.

1355 Reijmer, J.J., Swart, P.K., Bauch, T., Otto, R., Reuning, L., 1356 Roth, S. and Zechel, S., 2009. A Re-Evaluation of Facies on

1357 Great Bahama Bank I: New Facies Maps of Western Great

1358 Bahama Bank (pp. 29-46). International Association of

1359 Sedimentologists Special Publication 41, 29-46.

1360 Saint-Ange, F., Bachèlery, P., Babonneau, N., Michon, L. and

1361 Jorry, S.J., 2013. Volcaniclastic sedimentation on the

1362 submarine slopes of a basaltic hotspot volcano: Piton de la

1363 Fournaise volcano (La Réunion Island, Indian Ocean). Marine

1364 Geology, 337, 35-52. 
1365 Schott, F.A., Xie, S.P., McCreary, J.P., 2009. Indian Ocean

1366 circulation and climate variability. Reviews of Geophysics, 47,

$1367 \quad 1-46$.

1368 Shanmugam, G., 2000. 50 years of the turbidite paradigm

1369 (1950s-1990s): deep-water processes and facies models - $\mathrm{a}$

1370 critical perspective. Marine and Petroleum Geology, 17, 285-

1371342.

1372 Simpson, E.S.W., Schlich, R., Gieskes, J.M., Arch Girdley, W.,

1373 Leclaire, L., Marshall, B.V., Moore, C., Müller, C., Sigal, J.,

1374 Vallier, T.L., White, S.M., Zobel, B., 1974. Initial Reports of

1375 the Deep Sea Drilling Project, Sites 240-242, Volume 25,

1376 Washington (U.S. Government Printing Office) p. 65-176.

1377 Sisavath, E., Babonneau, N., Saint-Ange, F., Bachèlery, P.,

1378 Jorry, S.J., Deplus, C., De Voogd, B. and Savoye, B., 2011.

1379 Morphology and sedimentary architecture of a modern

1380 volcaniclastic turbidite system: The Cilaos fan, offshore La

1381 Réunion Island. Marine Geology, 288, 1-17.

1382 Talling, P.J., Masson, D.G., Sumner, E.J., Malgesini, G., 2012.

1383 Subaqueous sediment density flows: depositional processes and

1384 deposit types. Sedimentology, 59, 1937-2003.

1385 Tcherepanov, E.N., Droxler, A.W., Lapointe, P. and Mohn, K.,

1386 2008. Carbonate seismic stratigraphy of the Gulf of Papua 
mixed depositional system: Neogene stratigraphic signature and eustatic control. Basin Research, 20, 185-209.

1389 Testut, L., Duvat, V., Ballu, V., Fernandes, R.M., Pouget, F., 1390 Salmon, C., Dyment, J., 2016. Shoreline changes in a rising sea 1391 level context: The example of Grande Glorieuse, Scattered 1392 Islands, Western Indian Ocean. Acta Oecologica, 72, 110-119.

1393 Van Sebille, E., Scussolini, P., Durgadoo, J.V., Peeters, F.J., 1394 Biastoch, A., Weijer, W., Turney, C., Paris, C.B. and Zahn, R., 1395 2015. Ocean currents generate large footprints in marine 1396 palaeoclimate proxies. Nature Communications, 6, 6521.

1397 Wiles, E., Green, A.N., Watkeys, M.K. and Jokat, W., 2017.

1398 Zambezi continental margin: compartmentalized sediment 1399 transfer routes to the abyssal Mozambique Channel. Marine 1400 Geophysical Research, 38, 227-240.

1401 Wilson, P.A. and Roberts, H.H., 1995. Density cascading: off1402 shelf sediment transport, evidence and implications, Bahama 1403 Banks. Journal of Sedimentary Research, 65, 45-56.

1404 Yamano, H., Cabioch, G., Pelletier, B., Chevillon, C., 1405 Tachikawa, H., Lefêvre, J. and Marchesiello, P., 2015. Modern 1406 carbonate sedimentary facies on the outer shelf and slope 1407 around New Caledonia. Island Arc, 24, 4-15. 


\section{A: Geography}

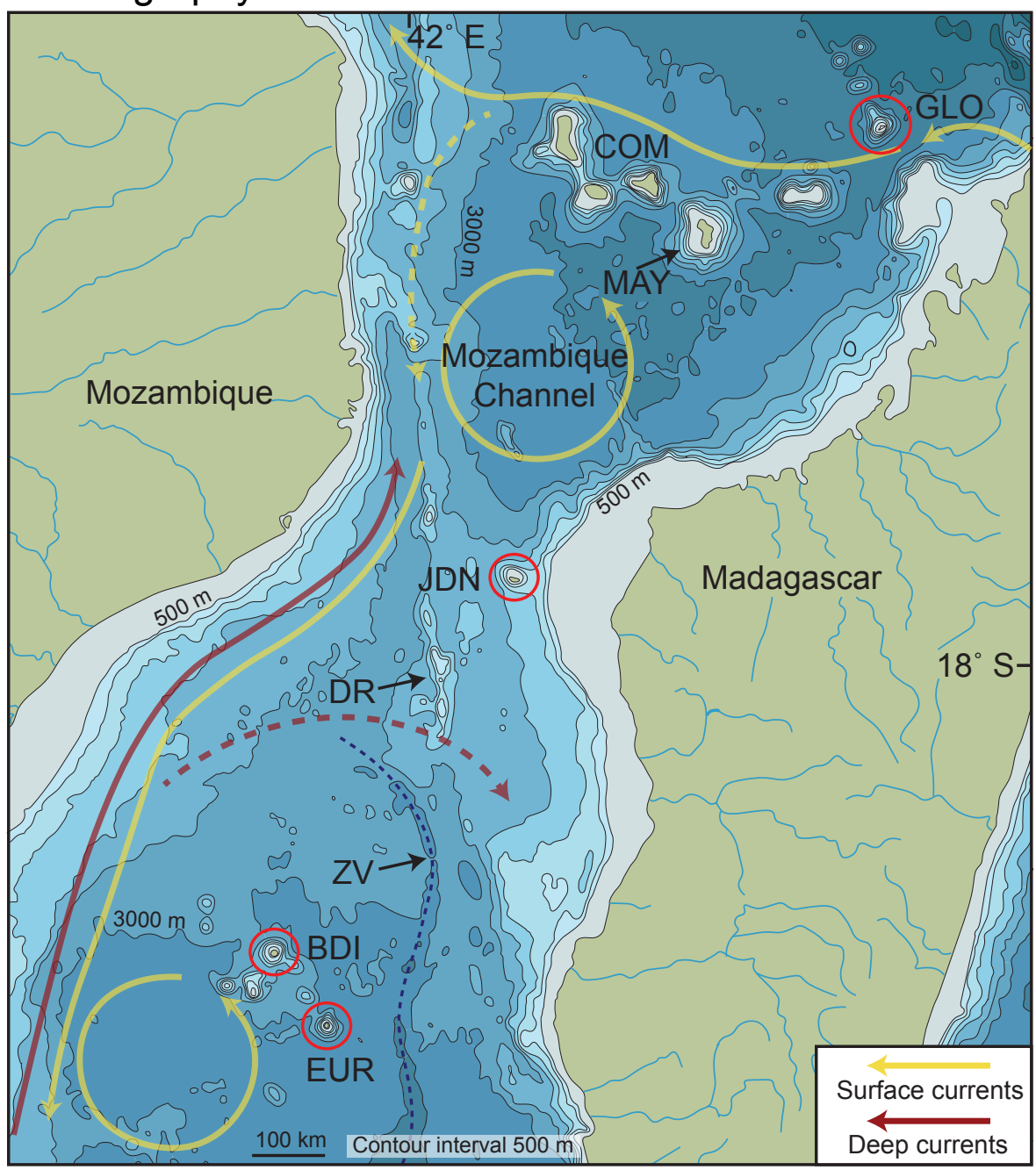

\section{B: Wind direction}
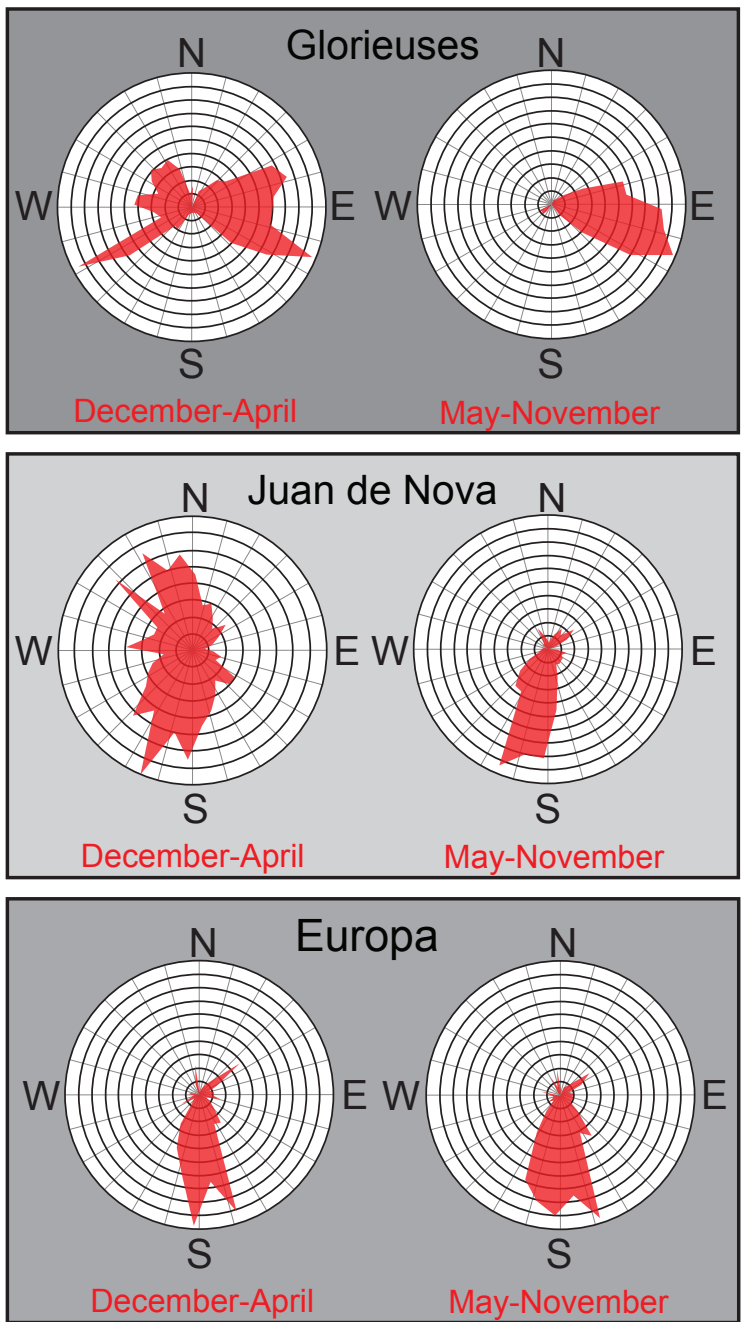

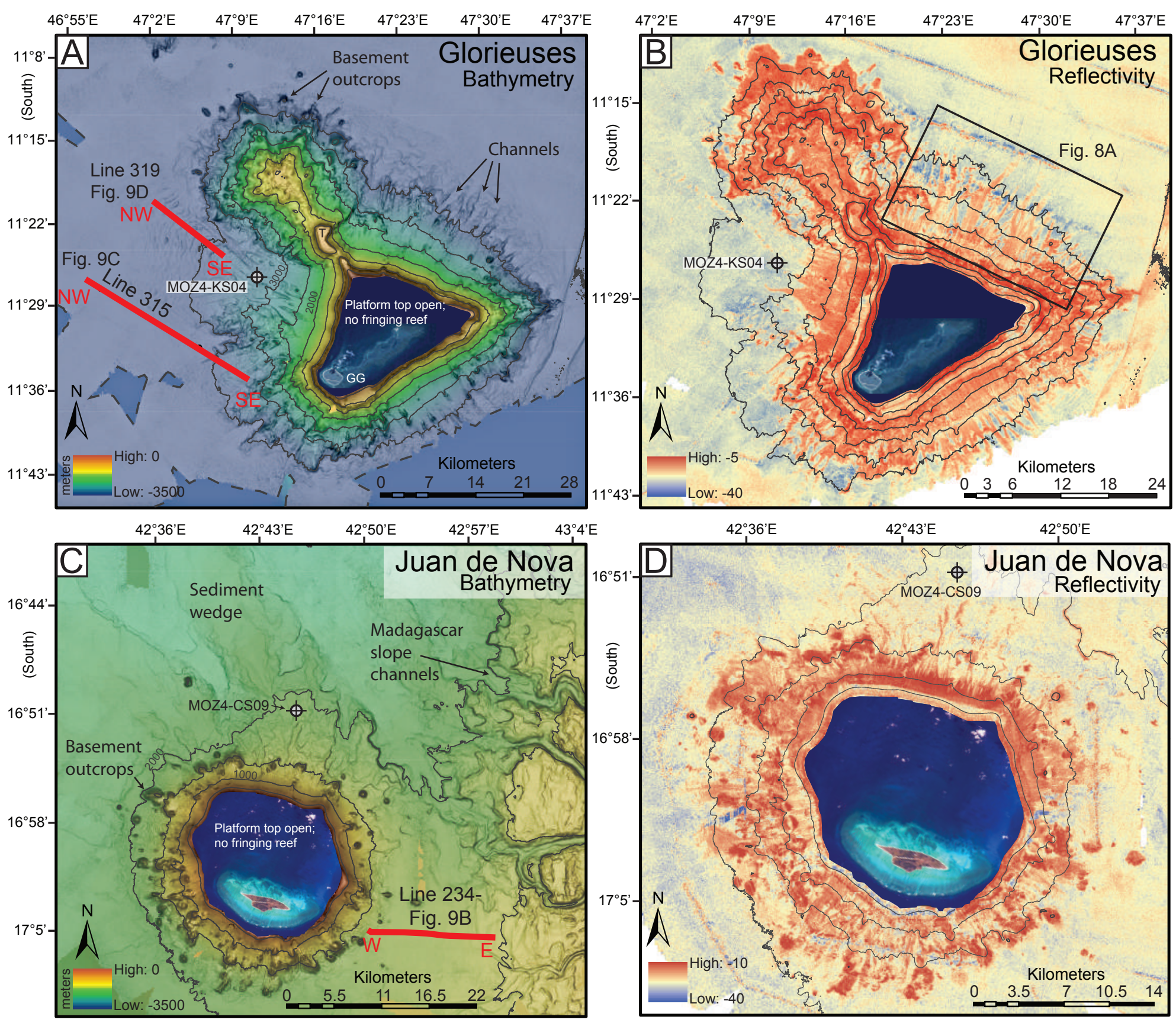

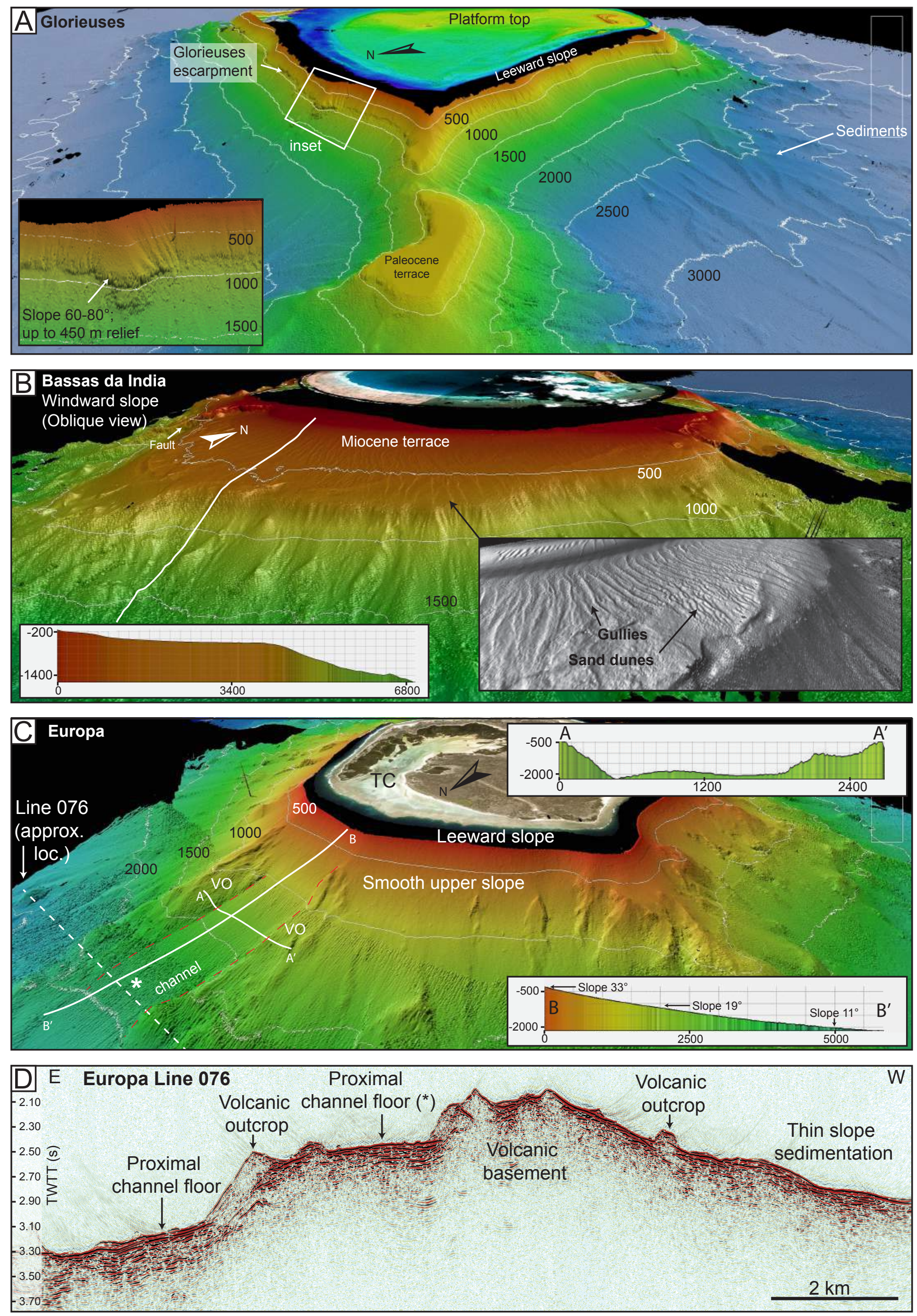

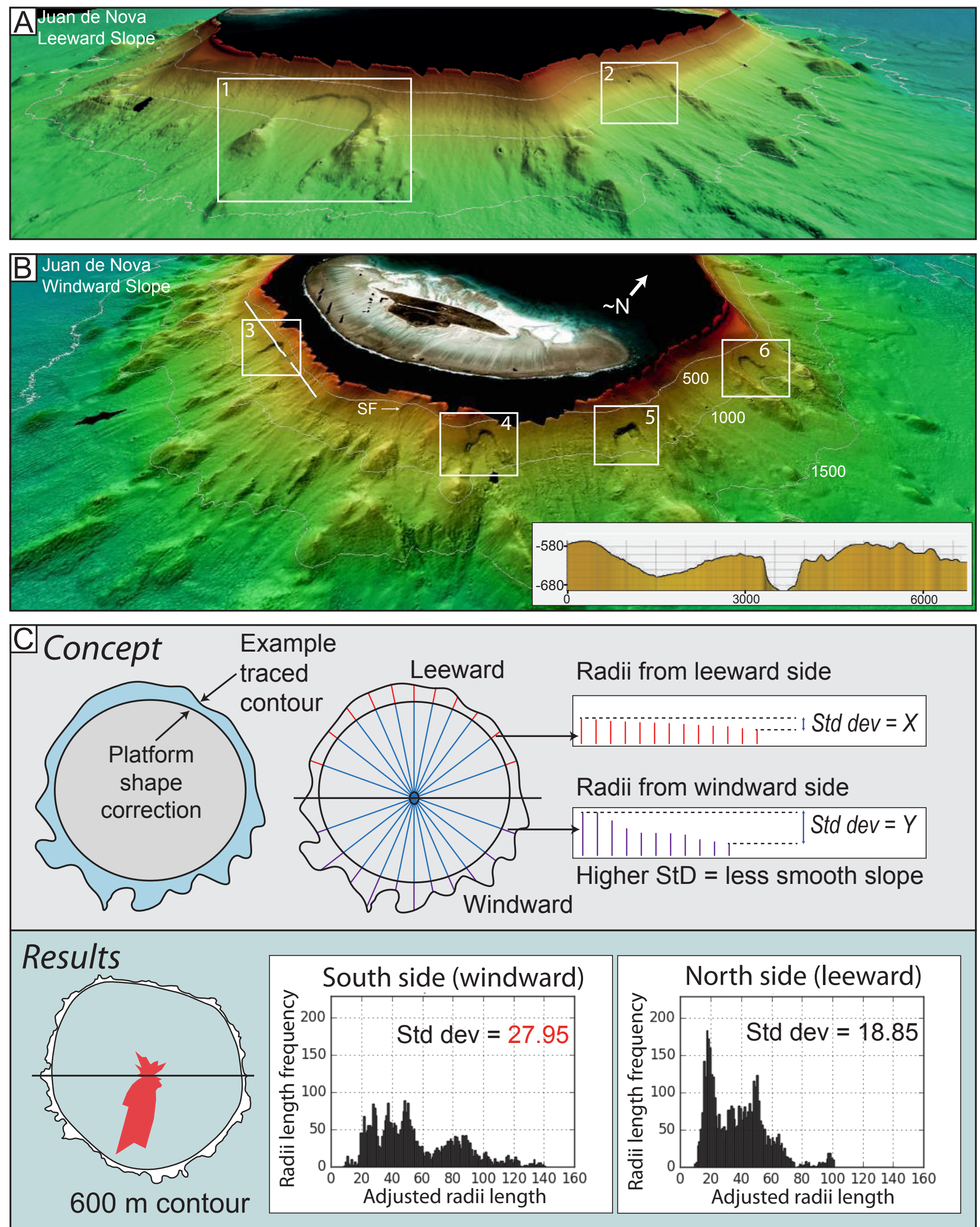


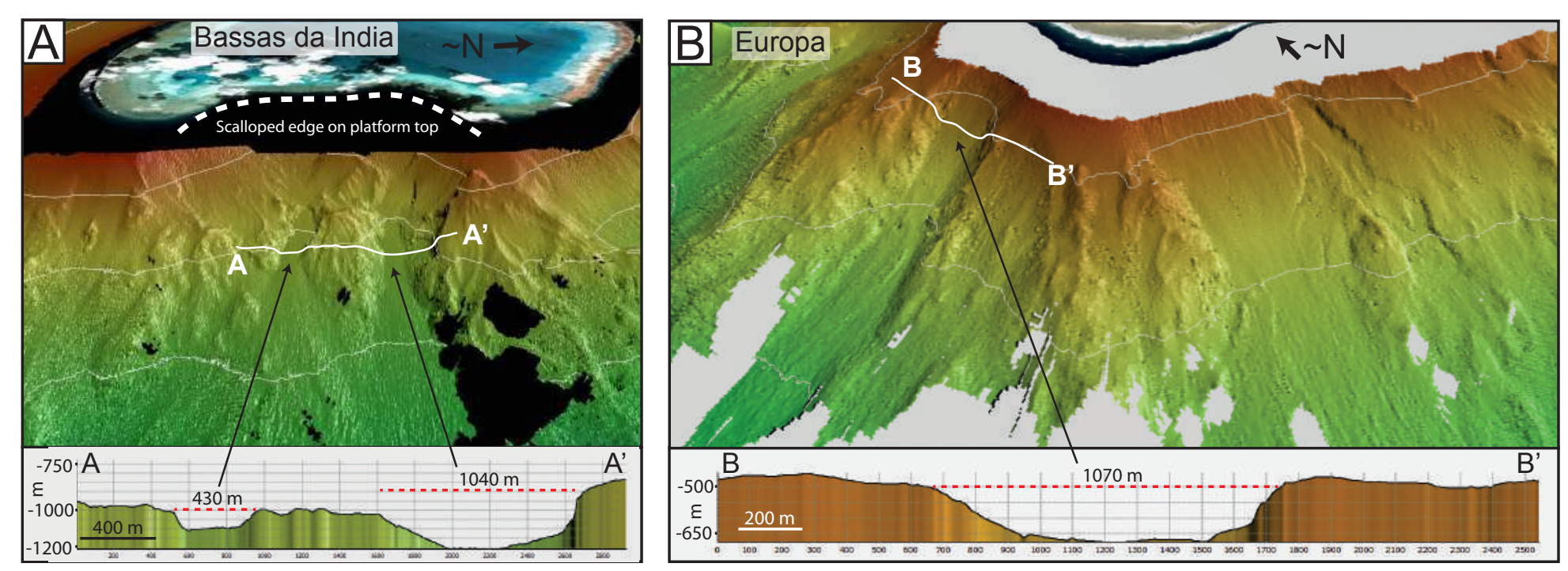




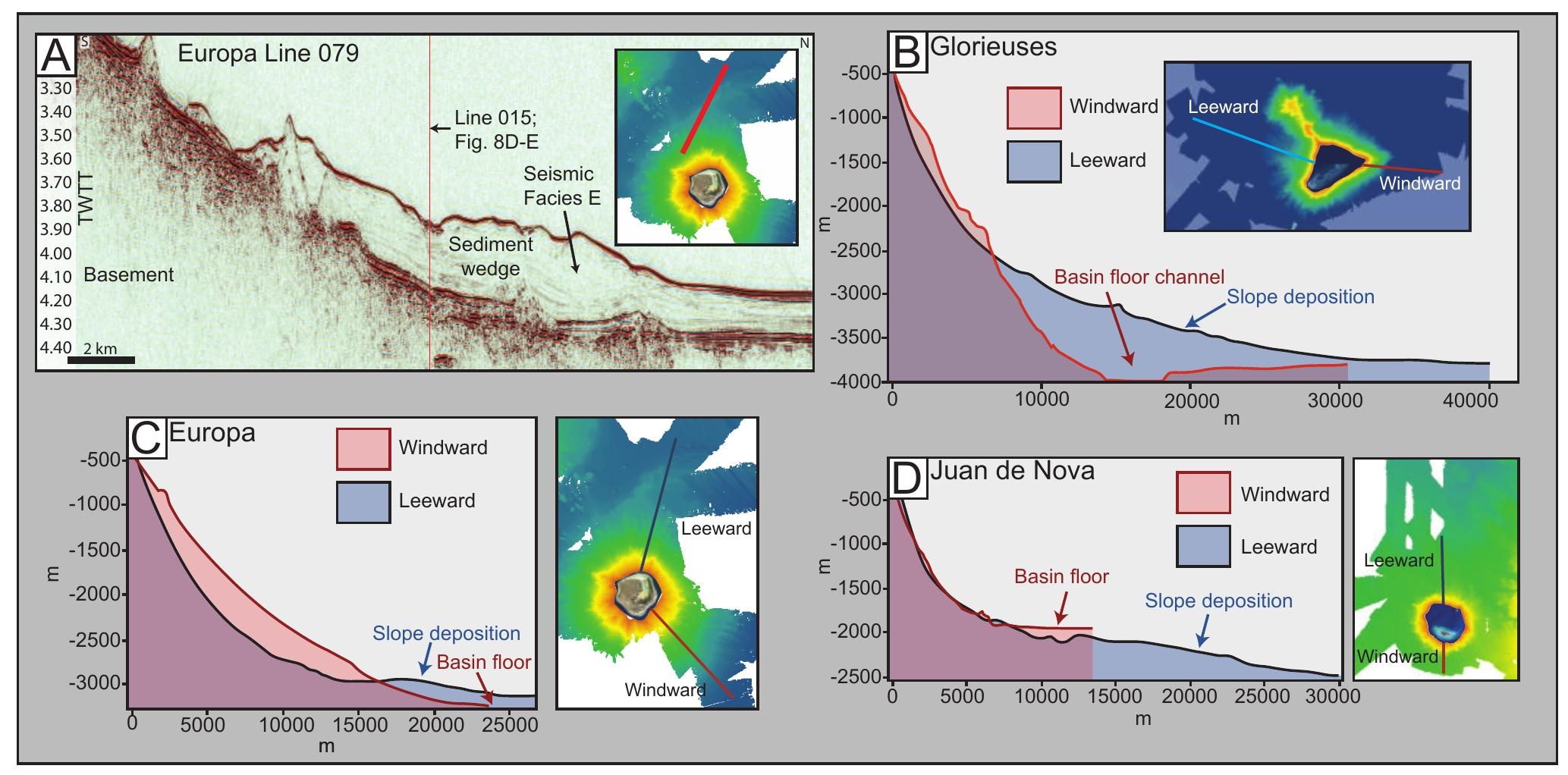




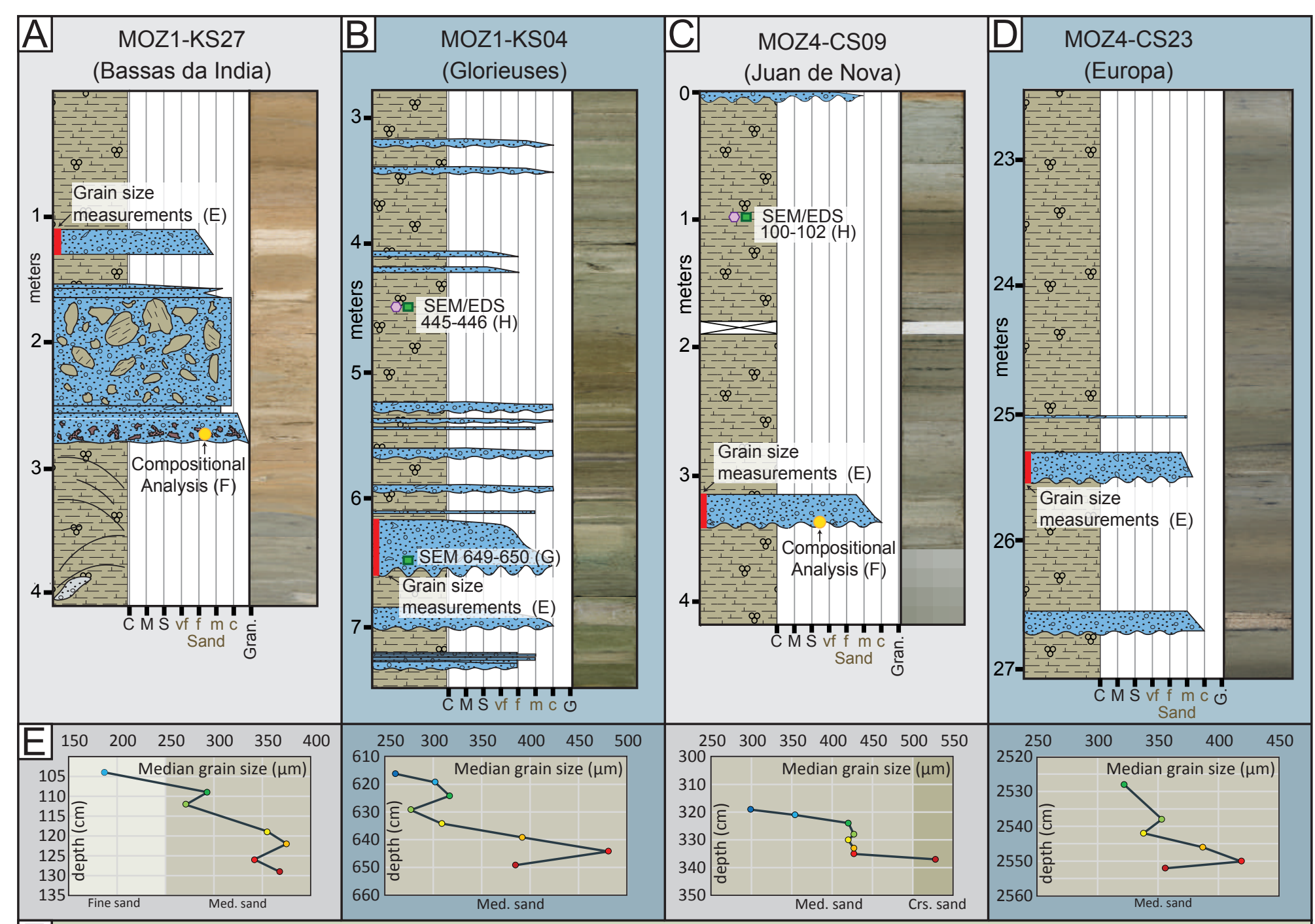

$\mathrm{F}$
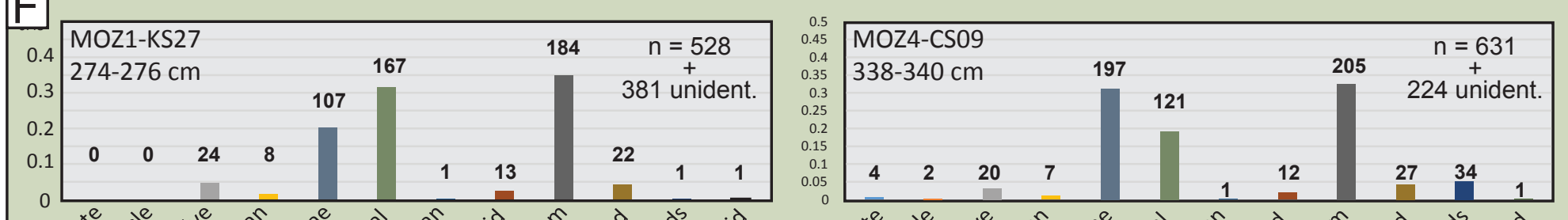

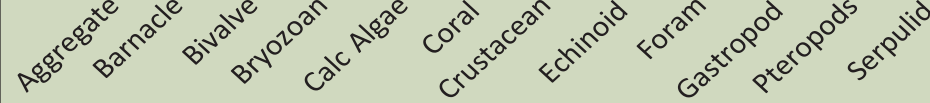

G MOZ1-KSO4 649-650 cm

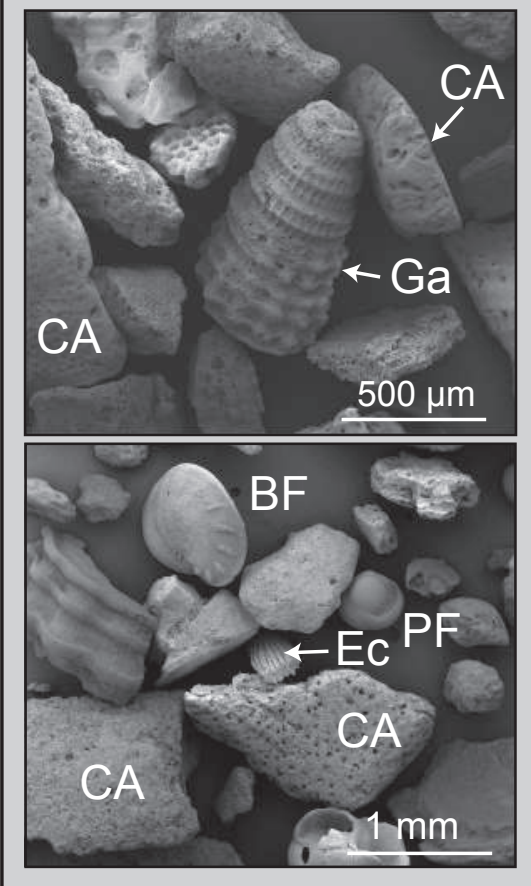

H] MOZ1-KS04 445-446 cm

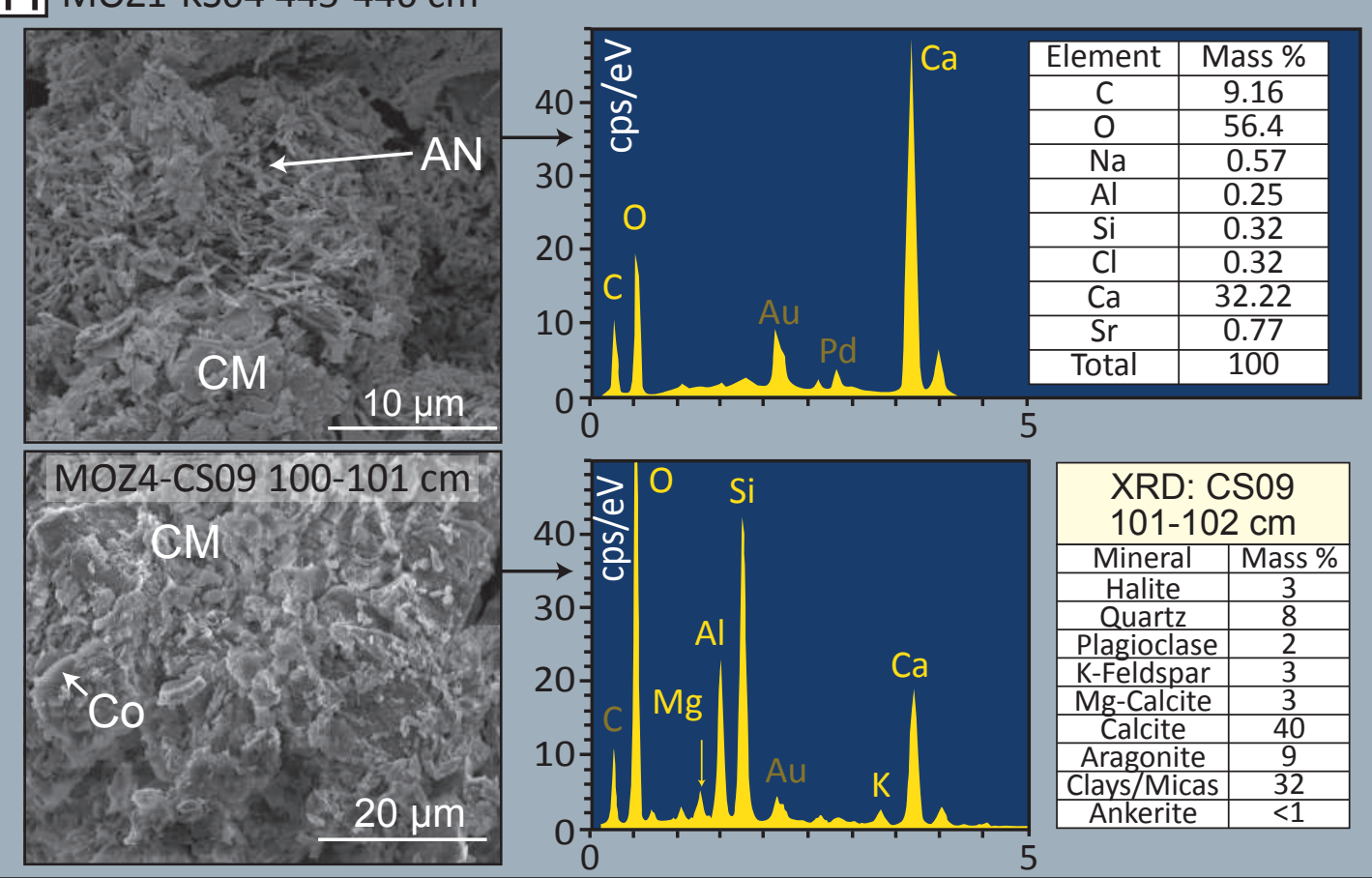



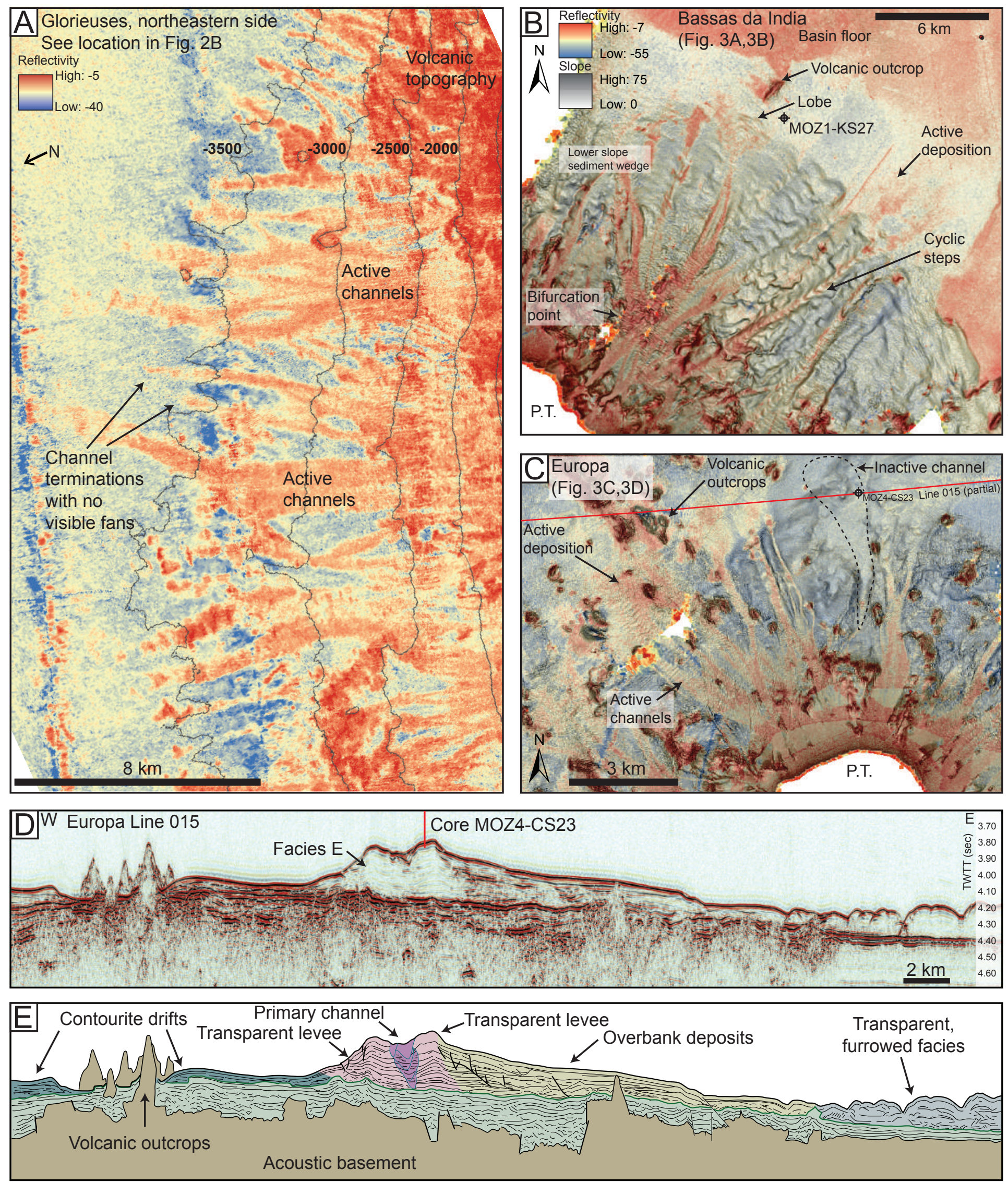

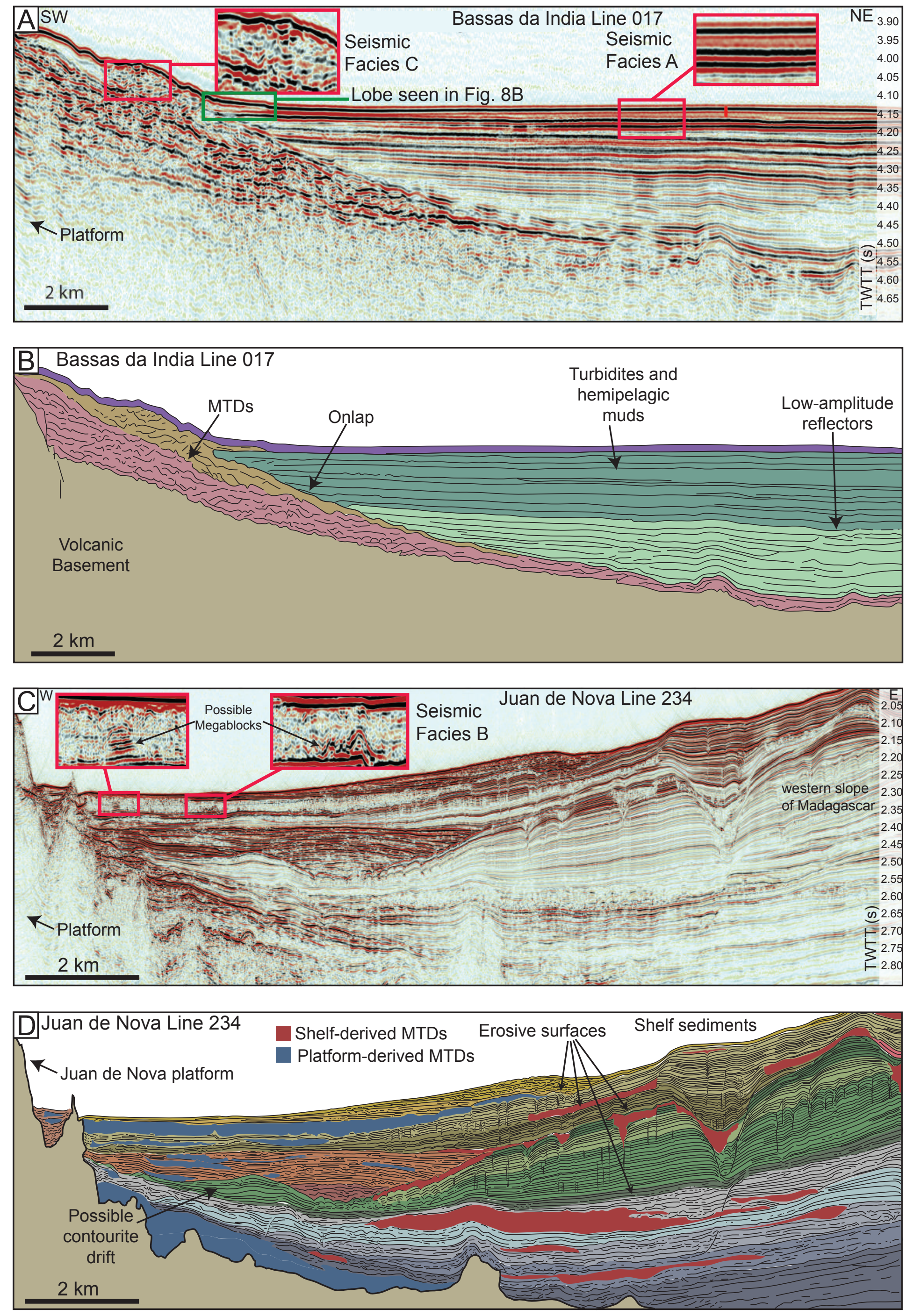

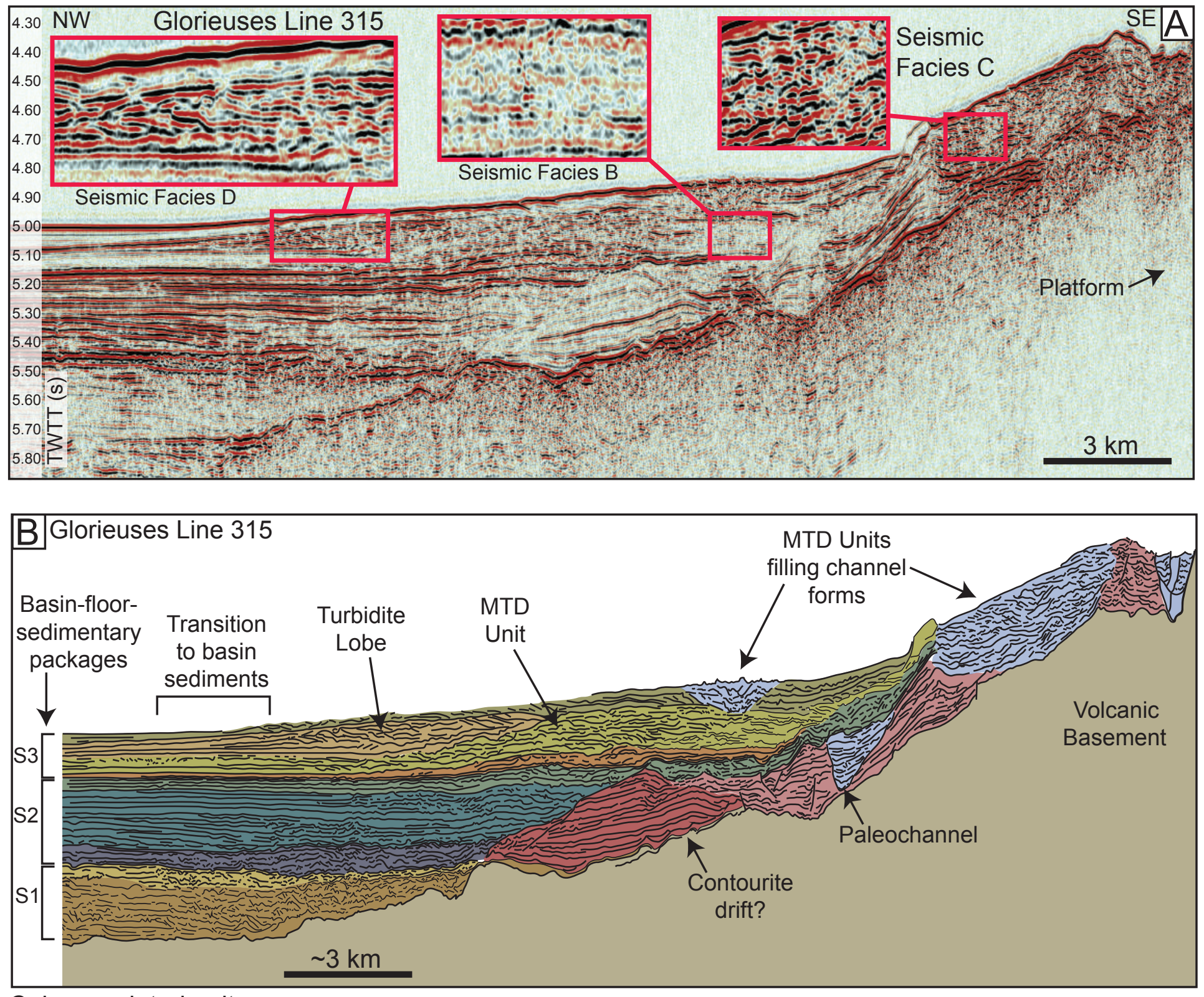

Colors $=$ related units 


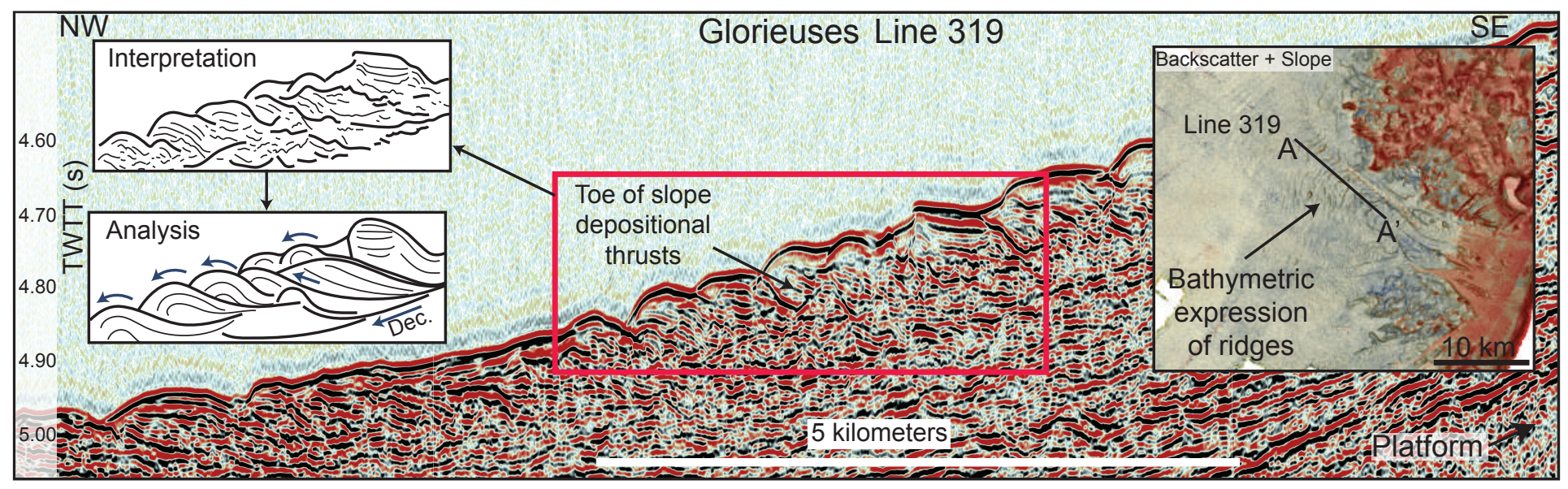



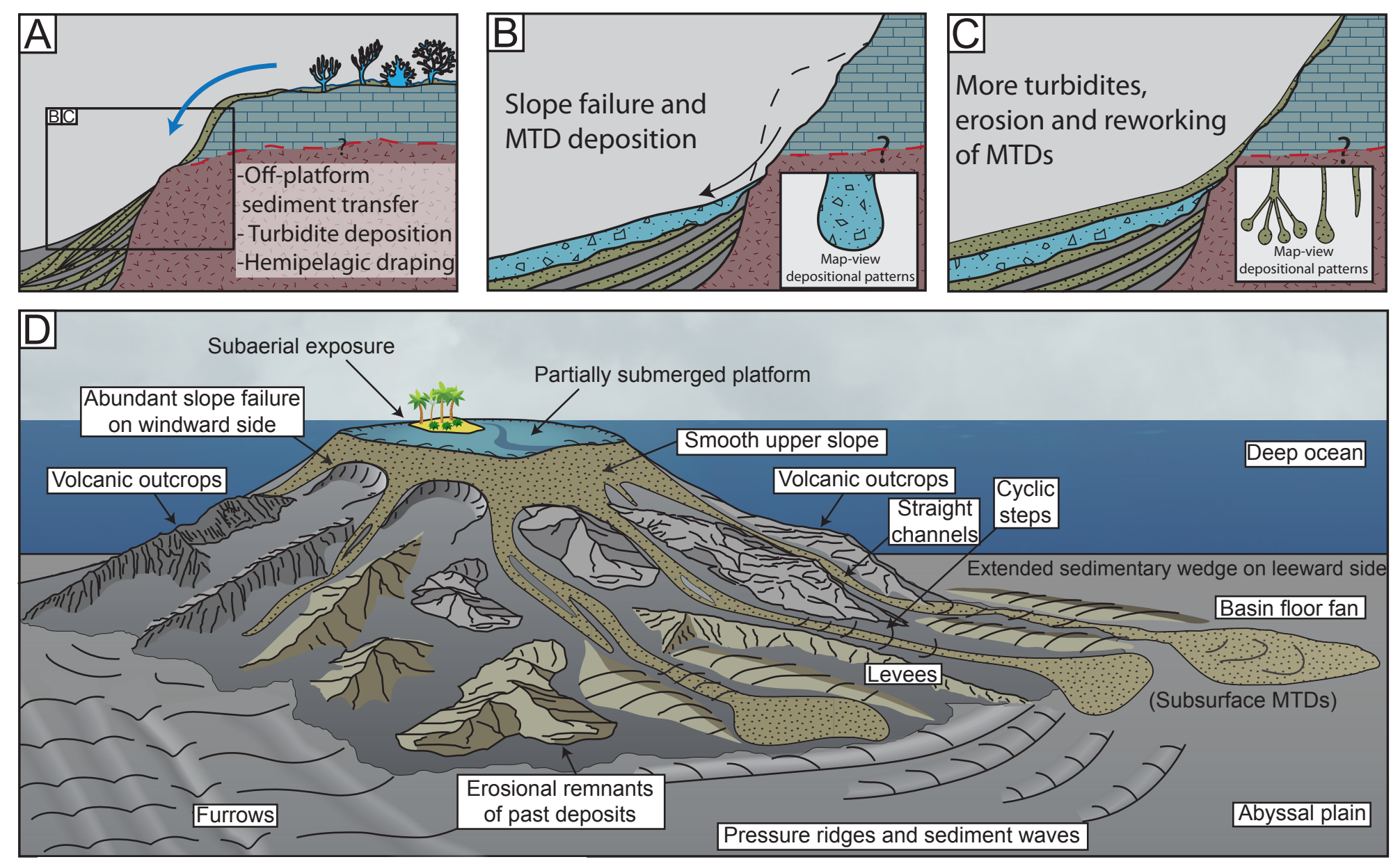


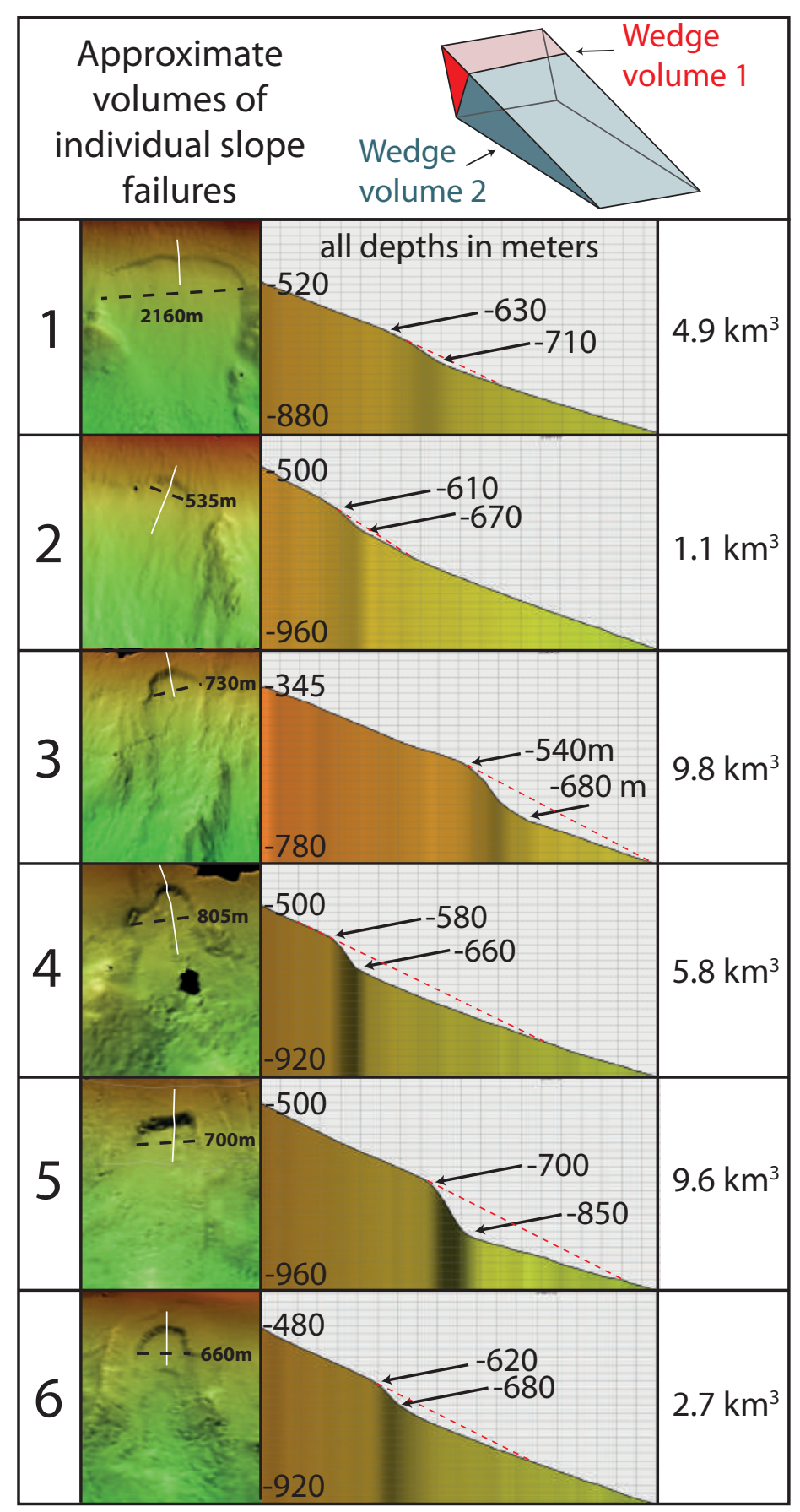




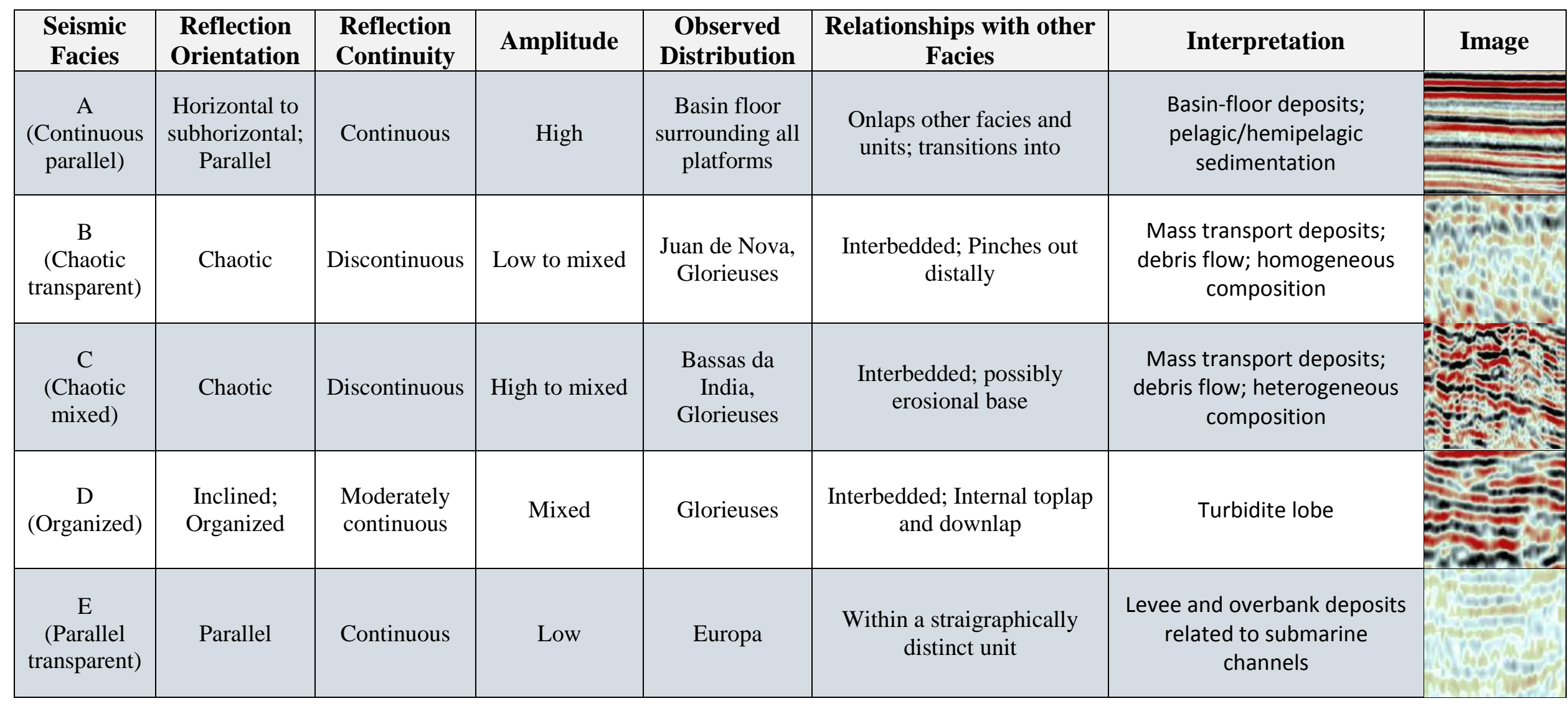




\begin{tabular}{|c|c|c|c|c|c|}
\hline $\begin{array}{c}\text { Geomorphologic or } \\
\text { Depositional } \\
\text { Element }\end{array}$ & Gradient & Approximate scale & Map-view shape & $\begin{array}{l}\text { Position relative } \\
\text { to platform }\end{array}$ & Extent \\
\hline Platform top & $0-3$ degrees & $50-200 \mathrm{~km}^{2}$ & $\begin{array}{c}\text { Round/equant/ } \\
\text { triangular }\end{array}$ & Top & N/A \\
\hline Channels & $\begin{array}{l}2-35 \text { degrees; more } \\
\text { similar to erosive } \\
\text { shallow canyons ar } \\
\text { slopes }>10 \text { degrees }\end{array}$ & \begin{tabular}{|c|} 
Generally $6-9 \mathrm{~km}$ \\
length, $200-400$ meters \\
width, with levees or \\
erosional walls $10 \mathrm{~s}$ of \\
meters high
\end{tabular} & Linear, straight & Radial on all sides & $\begin{array}{c}\text { Generally terminate } \\
12-18 \text { kilometers from } \\
\text { platform top }\end{array}$ \\
\hline Fans & 1-3 degrees & $\begin{array}{c}\text { On the order of } 1.5 \times 3 \\
\mathrm{~km} \text {, individually } \\
\text { variable }\end{array}$ & Cone/fan-shaped & $\begin{array}{l}\text { Leeward sides of BDI } \\
\text { and EUR }\end{array}$ & $\begin{array}{l}\text { At terminal end of } \\
\text { some channels, } 12-15 \\
\mathrm{~km} \text { from platform top }\end{array}$ \\
\hline Slope failure scars & $\begin{array}{c}\text { generally } \\
>22 \text { degrees }\end{array}$ & \begin{tabular}{|c|} 
On Juan de Nova, \\
$\sim 2-50 \mathrm{~km}$ in volume, \\
$500-2000$ meters \\
across. Elsewhere, \\
larger but less frequent
\end{tabular} & Arcuate wedge on JDN & $\begin{array}{l}\text { Upper slope, more } \\
\text { frequent on windward } \\
\text { side }\end{array}$ & $\begin{array}{c}\text { Scars confined to } \\
\text { upper slope; deposits } \\
\text { may extend into lower } \\
\text { slope or basin }\end{array}$ \\
\hline MTDs & $\begin{array}{c}\text { Variable but generally } \\
\text { found on lower slopes of } \\
\text { gradient }<10 \text { and usually } \\
<5 \text { degrees. }\end{array}$ & $\sim 7 \mathrm{~km}$ & $\begin{array}{c}\text { Wedge in } \\
\text { cross-section; unknown } \\
\text { in map view }\end{array}$ & $\begin{array}{l}\text { Occur on all sides; } \\
\text { more abundant on } \\
\text { leeward sides }\end{array}$ & $\begin{array}{l}\text { Visible in seismic up to } \\
35 \text { meters from } \\
\text { platform top }\end{array}$ \\
\hline
\end{tabular}

